\title{
Electrochemical Corrosion Study for Tank 241-AY-102 Sludge
}

\author{
J. Duncan for \\ CH2MHILL Hanford Group Inc., Richland, WA 99352 \\ Richland, WA 99352 \\ U.S. Department of Energy Contract DE-AC27-99RL14047
}

$\begin{array}{lll}\text { EDT/ECN: } & \text { EDT } 633355 & \text { UC: } \\ \text { Cost Center: } & 74 \text { T00 } & \text { Charge Code: } 501203 \\ \text { B\&R Code: } & & \text { Total Pages: } 97\end{array}$

Key Words: Tank 241-AY-102, sludge, electrochemical, corrosion potential, oxidation

Abstract: The report describes the analyses performed on core samples from the sludge region of the waste in Tank 241-AY-102 to determine the electrochemical corrosion potential.

TRADEMARK DISCLAIMER. Relerence herein to any specific commercial product, process, or service by trade name, tradernark, manufacturer, or otherwise, does not necessarily constitute or Imply its endorsement, recommendation, or favoring by the United States Government or any agency thereof or its contractors or subcontractors.

Printed in the United States of America. To obtain copies of lhis decument, contact: Document Control Services, P.O. Box 950, Mailstop H6-08, Richland WA 99352, Phone (509) 372-2420; Fax (509) 376-4989.

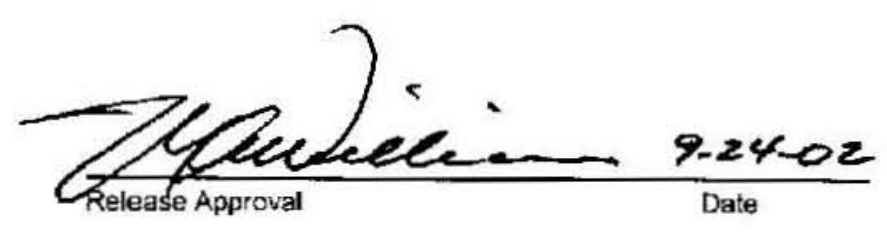

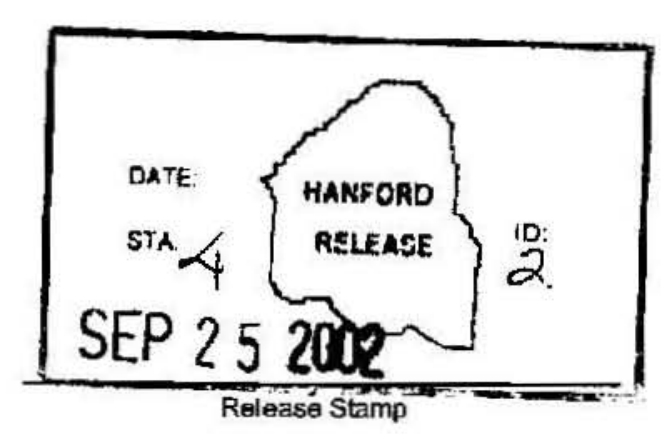

\section{Approved For Public Release}


RPP-12077

Revision 0

\title{
ELECTROCHEMISTRY CORROSION STUDY FOR TANK 241-AY-102 SLUDGE
}

\author{
J. B. Duncan \\ J. R. Divine \\ ChemMet, Ltd., PC \\ W. I. Winters \\ Numatec Hanford Corporation \\ C. F. Windisch \\ Pacific Northwest National Laboralory \\ K. G. Carothers \\ CH2M HILL Hanford Group, Inc.
}

Date Published

September 2002

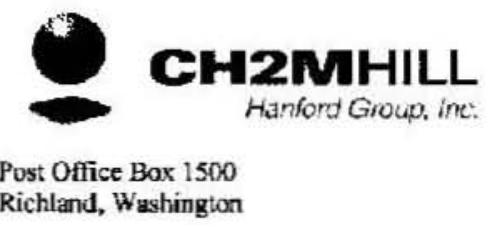

Prepared for the U.S. Department of Energy Office of River Protection

Contract No. DE-AC27-99RL14047

Approved for Public Release; Further Dissemination Unlimited 


\section{RPP 12077 Rev. 0}

\section{ACKNOWLEDGEMENTS}

The authors wish to acknowledge the efforts of the chemical technician, instrument technicians, and crafts at the 222-S Laboratory without whose knowledge, expertise, and positive "can-do" attitude this project would not have been accomplished in a timely manner. More specifically, the following individuals merit mention:

Mr. Florentino Gutierrez, chemical technician, who was instrumental in ensuring all phases and aspects of the project converged to meet schedule. Mr. James Pickens, instrument specialist whose electronics expertise was invaluable many times both in the transition to the hot cell environment and to the maintenance of the Princeton Applied Research instruments. Mr. Robert Bear, millwright, whose quick response to design changes facilitated the outcome of the electrochemical cell. The Mr. Michael Bausch, pipe fitter, who ensured the tank 241-AY-102 sample was kept in an anaerobic condition by a steady supply of argon purge gas. Mr. Ronald Hale, hot cell operations, who designed and oversaw the fabrication of the vertical extrusion platform. 
RPP 12077 Rev. 0

\section{EXECUTIVE SUMMARY}

Prior to chemical additions made to tank 241-AY-102 in February 2001 (sodium hydroxide) and November 2001 (sodium nitrite), the chemistry in the sludge region of the tank did not meet the requirements for corrosion control established in Technical Safety Requirements (TSR), Administrative Control (AC) 5.15, "Chemistry Control Program." Because there are no near-term alternatives available to correct the sludge chemistry, an understanding of the corrosion behavior of the waste in the sludge region of the tank was required. However, the sludge resides deep within the tank where its oxygen content may be low enough to significantly retard any corrosion mechanisms occurring at the tank wall.

The corrosion behavior of carbon steel samples immersed in tank 241-AY-102 sludge was investigated by performing potentiostatic and potentiodynamic anodic polarization measurements (hereinafter referred to as corrosion potential). The test results provided information on whether or not the type of carbon steel used in constructing the tank is susceptible to aggressive corrosion mechanisms when exposed to sludge material under the conditions of storage in the tank. The corrosion potential testing was designed to reflect the conditions of storage near the tank bottom, as was practicable. As a minimum, the sludge material was handled under an inert atmosphere at all times to preclude exposure to the oxygen in the atmosphere. To accomplish this, the sludge was sampled by the core sample method. This method isolated the sample in a sample holder during extraction from the tank and transport to the laboratory. The laboratory then devised a 
method to extrude the core segments and perform the corrosion potential testing while maintaining the waste material under inert conditions.

An extrusion platform designed to accept the core segment sampler was conceived. fabricated, and successfully tested. The extrusion platform allowed the extrusion of the core segments from tank 241-AY-102 under anaerobic conditions maintained with an argon gas purge of the sample material.

In order to minimize sample handling, a $500-\mathrm{mL}$ sample jar used in the 222-S Laboratory 11 A hot cell area for routine extrusions was configured as the electrochemical test cell. The ASTM G5-94, Standard Reference Test Method for Making Potentiosiatic and Potentiodynamic Anodic Polarization Measurements, was used to confirm both the measurement instrument operation and the efficacy of the 500 -mL electrochemical cell design.

Prior to beginning corrosion potential measurements of the tank sludge, synthetic tank 241-AY-102 supernatant and sludge were formulated in the standards laboratory for method verification testing. Electrochemical scans performed on the synthetic wastes were used to refine the cell design for optimum performance. After confirming the electrochemical cell design, the cell was tested using the long instrument cable leads fabricated to allow operation in 11 A3 hot cell. Potentiodynamic scans for this equipment arrangement were confirmed using the ASTM G5-94 method. 


\section{RPP 12077 Rev. 0}

Tank 241-AY-102 segment 13RI was anaerobically extruded directly into the electrochemical cell. Tests performed on segment $13 \mathrm{R} 1$ were conducted at $24^{\circ} \mathrm{C}$ and comprised linear polarization, Tafel, and potentiodynamic. When the temperature was raised to $40^{\circ} \mathrm{C}$, because of the paucity of water in the sample in the test cell and the constant purge of dry argon gas, the sample material dried out. This caused the sludge to shrink from around the carbon steel test coupon thereby breaking electrical continuity. The dried condition of the sample precluded further testing of the segment 13R1 material.

Core segments $13 \mathrm{BR}$ and $13 \mathrm{R}$ were anaerobically extruded and composited into the electrochemical cell. Based on lessons learned from the segment 13R1 testing, the argon purge gas was sparged through deionized water to humidify the dry gas before flowing into the headspace of the sample cell. This aided in maintaining the sample by preventing it from drying out. The composite of Segments $13 \mathrm{BR}$ and $13 \mathrm{R}$ was successfully scanned at $24^{\circ} \mathrm{C}, 40^{\circ} \mathrm{C}$, and $60^{\circ} \mathrm{C}$. To keep the test time at each elevated temperature to a minimum, only the potentiodynamic scan was performed. The potentiodynamic scan covers the Tafel scan region, thereby allowing computation of corrosion rates.

The comosion potential measurement results indicate that the general corrosion rates for tank 241-AY-102 sludge in contact with carbon steel of the type used in the tank construction range between $10^{-1}$ to $10^{-2}$ mills per year. This corrosion rate is more than an order of magnitude lower than the 1 mill per year design basis for the tank. The potentiodynamic scan also shows that the carbon steel test coupon exposed to sludge 


\section{RPP 12077 Rev. 0}

from the bottom of the tank falls in the passive region of the scan where general corrosion mechanisms are dominant. No evidence of an active-passive region was observed in the scan, which if present could have reflect a potential for stress corrosion cracking.

Subsequent chemical analysis of a sample of tank 241-AY-102 sludge material from the bottom region of the tank showed that the sludge composition just met the lower limits of AC 5.15 chemistry control range. Consequently, the electrochemical corrosion potential measurements of the tank $241-\mathrm{AY}-102$ sludge primarily serve to confirm that the lower limits of the Administrative Control are justified for this waste. 


\section{TABLE OF CONTENTS}

EXECUTIVE SUMMARY ES-2

1.0 INTRODUCTION

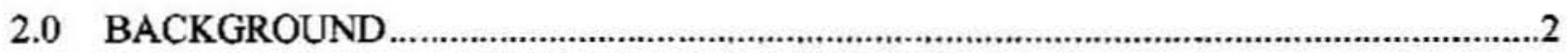

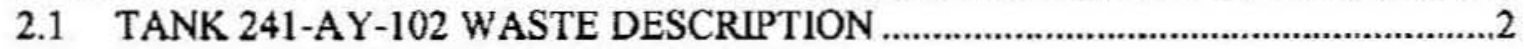

2.2 BASIC ELECTROCHEMISTRY THEORY ….........................................................

2.2.1 General Relationship Between Corrosion and Electrochemistry ......................5

2.2.2 Polarization Resistance ............................................................................6

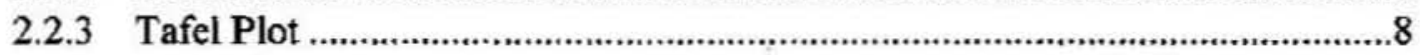

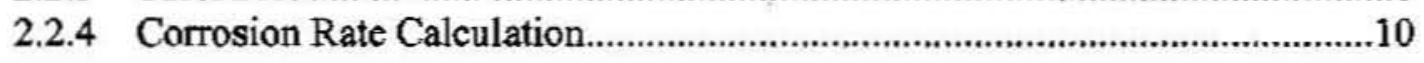

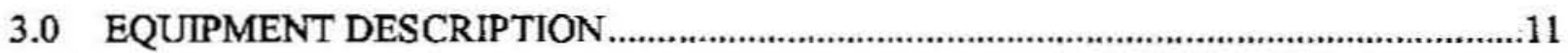

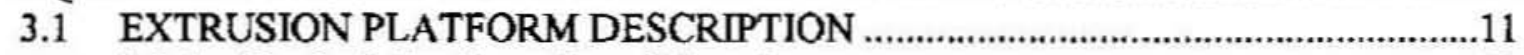

3.1.1 Vertical Configuration of Sampler ................................................................11

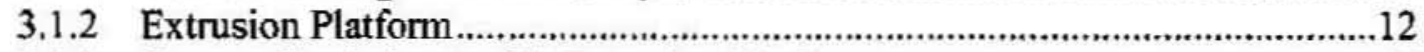

3.1.3 Oxygen Depletion Inside Extrusion Platform.................................................17

3.2 REMOTE ELECTROCHEMICAL CELL DESCRIPTION ......................................18

3.2.1 Configuration of Electrochemical Cell Cover ...............................................19

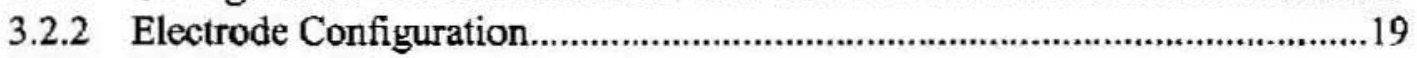

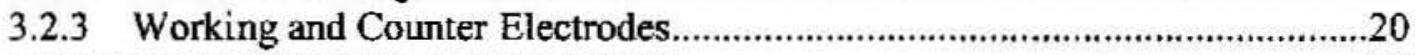

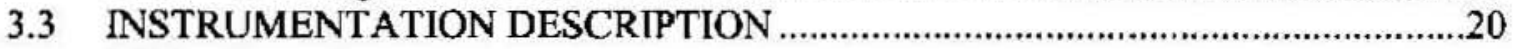

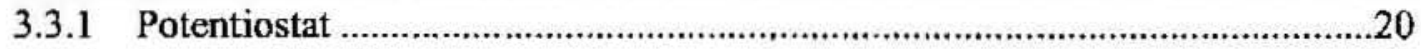

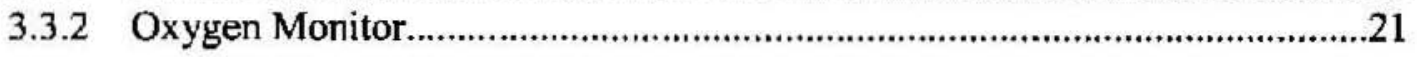

4.0 METHOD VERIFICATION TESTING ....................................................................22

4.1 ASTM G5-94 METHOD TESTING …................................................................22

4.1.1 Instrument Operation and Remote Electrochemical Cell Performance...........23

4.1.2 Instrument Operation with Long Cable Leads.............................................23

4.2 TANK 241-AY-102 WASTE SIMULANT TESTING...........................................25

4.2.1 Platinum to Platinum Scan Tests ...............................................................2.25

4.2.2 Tank 241-AY-102 Supernatant Simulant Testing .......................................25

4.2.3 Tank 241-AY-102 Sludge Simulant Testing .................................................26

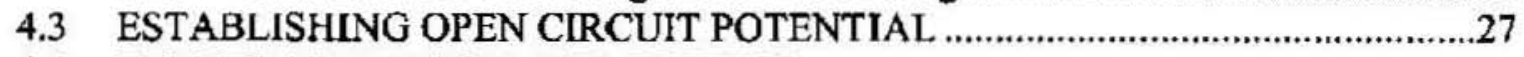

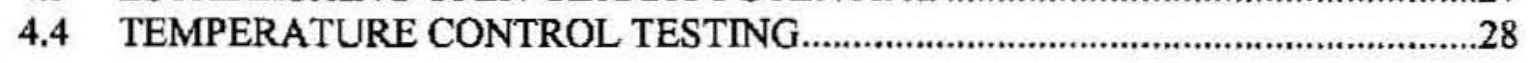

5.0 TANK 241-AY-102 SLUDGE CORROSION POTENTIAL TEST RESULTS.................30

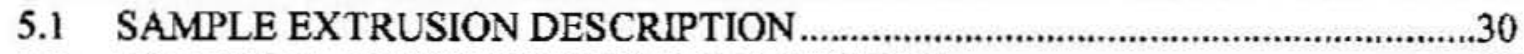

5.2 CHEMICAL ANALYSIS OF CORE SEGMENTS ................................................32

5.3 TANK 241-AY-102 SEGMENT 13R1 CORROSION POTENTIAL TESTING .....32

5.3.1 Segment 13R1 Extrusion ...............................................................................32

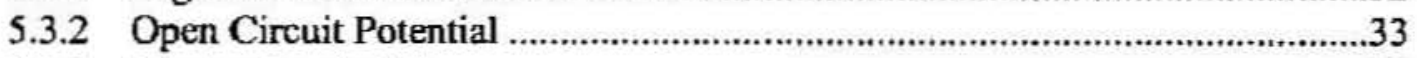

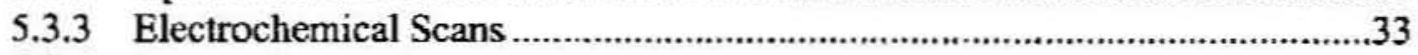

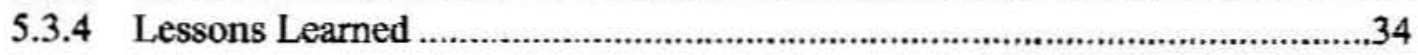




$$
\text { RPP } 12077 \text { Rev. } 0
$$

\subsection{TANK 241-AY-102 SEGMENTS 13R AND 13BR COMPOSITE CORROSION} CONTROL TESTING

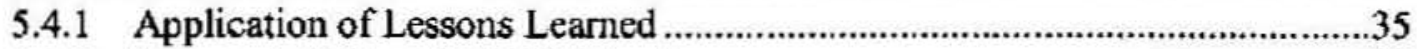

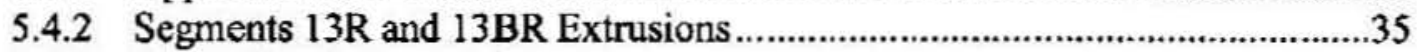

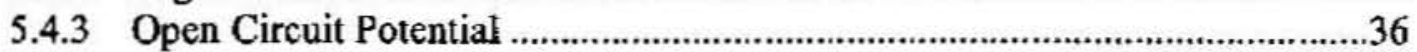

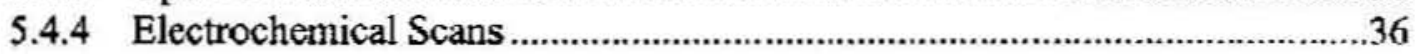

6.0 DISCUSSION OF TANK 241-AY-102 SLUDGE CORROSION POTENTIAL TEST

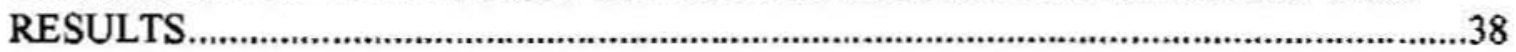

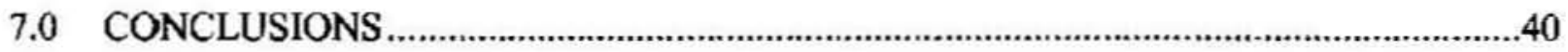

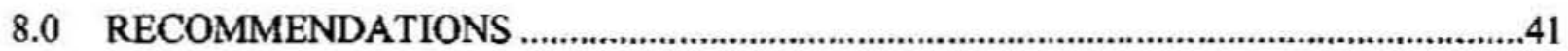

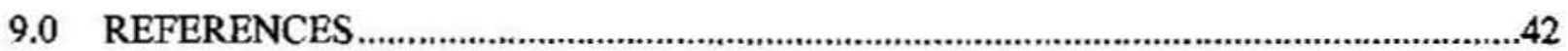

\section{APPENDICES}

A TEST PLAN/PROCEDURE FOR ELECTROCHEMICAL CORROSION TESTING OF A515 CARBON STEEL IN 241-AY-102 SLUDGE.............................................. A-1

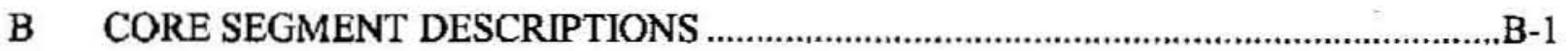

C DATA SUMMARY AND OPPORTUNISTIC ANALYTE RESULTS ............................

D TANK 241-AY-102 SIMULANT FORMULATIONS ............................................... D-1

E ELECTROCHEMICAL SCANS SEGMENT 13R1 ................................................... E-1

F ELECTROCHEMICAL SCANS OF SEGMENTS 13R1 AND 13BR .......................... F-1 


\section{LIST OF FIGURES}

Figure 2-1. Tank 241-AY-102 Core Profile ..........................................................................4

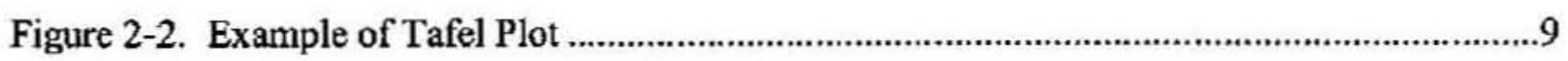

Figure 3-1. Bottom Plate of Extrusion Platform ...................................................................12

Figure 3-2. Electrochemical Cell in Position.......................................................................13

Figure 3-3. Middle Plate in Position ................................................................................13

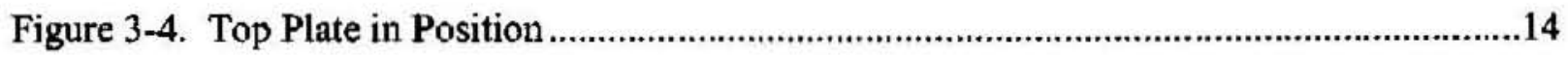

Figure 3-5. Extrusion Platform with Plexiglas $₫$ Enclosure .....................................................14

Figure 3-6. Complete Extrusion Platform with Sampler in Position ...........................................15

Figure 3-7. Directional Openings in Top Plate of Extrusion Platform ......................................16

Figure 3-8. Sampler Collar with Argon Gas Inlet....................................................................16

Figure 3-9. Extrusion Platform Enclosure Oxygen Depletion as a Function of Time..................18

Figure 3-10. Plan View of Electrochemical Cell Cover ..........................................................19

Figure 3-11. 500-mL Electrochemical Cell Cover …............................................................20

Figure 4-1. The ASTM G5-94 Method Run by the PAR 273 Using Standard 1-Liter Test Cell. 22

Figure 4-2. Response of 500-mL Electrochemical Cell to the ASTM G5-94 Method...............23

Figure 4-3. Response of 500-mL Test Cell with Long Cable Leads in 222-SA Laboratory.......24

Figure 4-4. Response of 500-mL Test Cell with Long Cable Leads in 11 A.3 Hot Cell..............24

Figure 4-5. Current Densities for Tank 241-AY-102 Supernatant Simulant.............................26

Figure 4-6. Current Densities for Tank 241- AY-102 Sludge Simulant.....................................26

Figure 4-7. Open Circuit Potential in Tank 241-AY-102 Sludge Simulant ................................27

Figure 4-8. Open Circuit Potential in Tank 241-AY-102 Core Segment 13R1 Sludge ..............28

Figure 4-9. Electrochemical Cell Temperature Gradient for Heated Tank 241-AY-102 Sludge

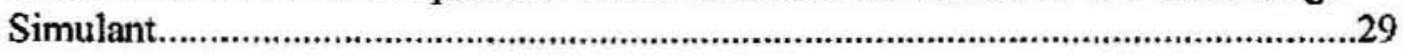

Figure 5-1. Extrusion of Tank 241-AY-102 Sludge Into Electrochemical Cell ..........................31 
RPP 12077 Rev. 0

Figure 5-2. Tank 241-AY-102 Core Segment 13R1 Sludge Potentiodynamic Scan at $24{ }^{\circ} \mathrm{C}$.......33

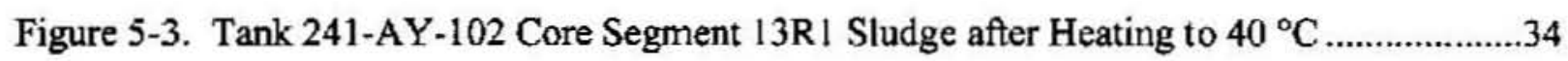

Figure 5-4. Tank 241-AY-102 Core Segment 13R1 and 13BR Composite Potentiodynamic

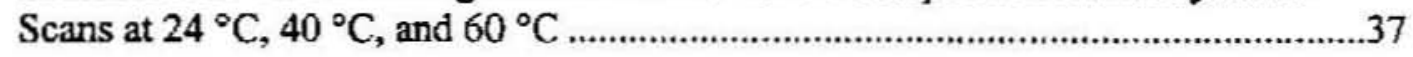

\section{LIST OF TABLES}

Table 3-1. Extrusion Platform Argon Purge Test Arrangements .................................................17

Table 5-1. Segment Classification, Visual Observation ................................................................31

Table 6-1. Corrosion Rates Calculated from the Scans of Tank 241-AY-102 Sludge ..................38

Table 6-2. Comparison of Corrosion Rates Derived by Hand Calculations to Corrosion Rates

Derived by Software ...................................................................................................38 
RPP 12077 Rev. 0

\section{LIST OF TERMS}

$\begin{array}{ll}\text { AC } & \text { Administrative Control } \\ \text { ASTM } & \text { American Society for Testing and Materials } \\ \mathrm{cm} & \text { centimeters } \\ \mathrm{cm}^{2} & \text { square centimeters } \\ \text { DST } & \text { double-shell tank } \\ \mathrm{g} / \mathrm{L} & \text { grams per liter } \\ \mathrm{GPIB} & \text { General Purpose Interface Bus } \\ \mathrm{ICP} & \text { inductively coupled plasma } \\ \mathrm{IEEE} & \text { Institute of Electrical and Electronic Engineers } \\ \text { in. } & \text { inches } \\ \mathrm{kgal} & \text { kilogallons } \\ \mathrm{kL} & \text { kiloliters } \\ \mathrm{m} & \text { meters } \\ \mathrm{M} & \text { moles per liter } \\ \mathrm{mL} & \text { milliliters } \\ \mathrm{mM} & \text { millimolar } \\ \mathrm{mpy} & \text { milli-inches per year } \\ \mathrm{mV} & \text { millivolts } \\ \mathrm{mV} / \mathrm{sec} & \text { millivolts per second } \\ N & \text { Normality } \\ \mathrm{n} / \mathrm{a} & \text { not applicable } \\ \text { psi } & \text { pounds per square inch } \\ \mathrm{sec} & \text { seconds } \\ \mathrm{SpG} & \text { specific gravity } \\ \mathrm{SST} & \text { single-shell tank } \\ \mathrm{TGA} & \text { thermogravimetric analysis } \\ \mathrm{TIC} & \text { total inorganic carbon } \\ \mathrm{TOC} & \text { total organic carbon } \\ \mathrm{TSR} & \text { Technical Safety Requirement } \\ \mathrm{USB} & \text { Universal Serial Bus } \\ \mathrm{V} & \text { volts } \\ { }^{\circ} \mathrm{C} & \text { degrees Celsius } \\ { }^{\circ} \mathrm{F} & \text { degrees Fahrenheit } \\ \mu \mathrm{A} & \text { microamps } \\ \mu \mathrm{g} / \mathrm{g} & \text { micrograms per gram } \\ \mu \mathrm{g} / \mathrm{mL} & \end{array}$




\subsection{INTRODUCTION}

Prior to chemical additions made to tank 241-AY-102 in February 2001 (sodium hydroxide) and November 2001 (sodium nitrite), the chemistry in the sludge region of the tank did not meet the requirements for corrosion control established in Technical Safety Requirements (TSR), Administrative Control (AC) 5.15, "Chemistry Control Program" (CHG 2002). The chemicals, which were added to the tank supernatant, were expected to mix with the sludge over a long time period by natural processes occurring in the waste (Jo et al. 2002). Because there are no near-term alternatives available to correct the sludge chemistry, an understanding of the corrosion behavior of the waste in the sludge region of the tank was required. However, the sludge resides deep within the tank where its oxygen content may be low enough to significantly retard any corrosion mechanisms occurring at the tank wall.

A TSR recovery plan (Recovery Plan for Addition of Nitrite to Tank 241-AY-102) was issued to return the out-of-compliance condition of the sludge to within the AC 5.15 nitrite concentration limits ( $O^{\prime}$ Connor 2002). The Recovery Plan required the potentiostatic and potentiodynamic anodic polarization measurements (hereinafter referred to as corrosion potential) of carbon steel samples immersed in tank 241-AY-102 sludge in order to evaluate the corrosion characteristics of the carbon steel wall in the knee-region of the tank where the sludge is in contact. The test measurements provide information on whether or not the type of carbon steel used in constructing the tank is susceptible to aggressive corrosion mechanisms when exposed to sludge material under the conditions of storage in the tank. These tests are patterned after American Society for Testing and Materials (ASTM) procedure G5-94, "Standard Reference Test Method for Making Potentiostatic and Potentiodynamic Anodic Polarization Measurements" (ASTM 1999).

The corrosion potential testing is to be designed to reflect the conditions of storage near the tank bottom, as is practicable. As a minimum, the sludge material needs to be handled under an inert atmosphere at all times to preclude exposure to the oxygen in the atmosphere. To accomplish this, the sludge is sampled by the core sample method. This method isolates the sample in a sample holder during extraction from the tank and transport to the laboratory. The laboratory then needs to devise a method to extrude the core segments and perform the corrosion potential testing while maintaining the waste material under inert conditions.

Fluor Hanford, Inc., Technology Project Management, was contracted to anaerobically extrude the tank 241-AY-102 sludge core segments and to measure the corrosion potential of sludge material in contact with carbon steel coupons (FH 2002). Guidance for the extrusion and comosion potential testing was documented in an approved test plan (Winters 2002), which is included as Appendix A. Steel specimens of A515 Grade 60 carbon steel similar to that used in the tank's construction were specified for use in the measurements. The test plan calls for utilizing potentiodynamic polarization scans to 
establish such factors as open circuit corrosion potential, Tafel constants, polarization resistance, passivation regions, and corrosion rates. The corrosion tests are to be carried out at ambient temperature $\left(24^{\circ} \mathrm{C}\right.$ ), $40^{\circ} \mathrm{C}$, and $60^{\circ} \mathrm{C}$ (the expected maximum seasonal tank temperature).

\subsection{BACKGROUND}

\subsection{TANK 241-AY-102 WASTE DESCRIPTION}

Tank 241-AY-102 is a double-shell tank (DST) that is located in the 200 East Area 241-AY Tank Farm. The tank went into service in 1971. Tank 241-AY-102 received dilute wastes from numerous single-shell tanks (SSTs), DSTs, the Plutonium Uranium Extraction (PUREX) Plant, B-Plant, N Reactor, T-Plant, and laboratories in the 200, 300, and 400 areas. Wastes were transferred from tank $241-\mathrm{AY}-102$ to various SSTs, DSTs, and the 242-A Evaporator. In July 1998, 1,473 kL (389 kgal) of dilute non-complexed waste was transferred from tank 241-AY-102 to tank 241-AW-102. From November 1998 until October 1999, 97 percent of the high-heat sludge from tank $241-\mathrm{C}$-106 was sluiced to tank 241-AY-102, using the supernatant in tank 241-AY-102 as the sluicing medium. Sodium hydroxide and sodium nitrite were added to the tank in 2001 to comply with corrosion control requirements.

The best-basis inventory (BBI) total volume as of August 21,2001 was $2,403 \mathrm{~kL}$ (635 kgal) (CHG 2001a). As of January 15, 2002, tank 241-AY-102 contained approximately $2,564 \mathrm{~kL}$ ( $677 \mathrm{kgal}$ ) of waste (CHG $2001 \mathrm{~b}$ ). This volume is derived from an Auto ENRAFTMl surface level measurement of $6.26 \mathrm{~m}$ (246.35 in.) of waste as measured from the bottom centerline of the tank. The waste consists of approximately $1,918 \mathrm{~kL}(507 \mathrm{kgal})$ of supernatant and approximately $646 \mathrm{~kL}(171 \mathrm{kgal})$ of sludge. The sludge is not uniformly distributed on the bottom of the tank. On January 14, 2002, temperature readings at various depths within the tank ranged from 100 to $135^{\circ} \mathrm{F}$ (38 to $\left.57^{\circ} \mathrm{C}\right)(\mathrm{CHG} 2001 \mathrm{c})$.

The sampling and analysis event for the 241-AY-102 samples used in the electrochemical measurements is described in a tank sampling and analysis plan (Rasmussen 2002). The tank sludge was originally deficient in nitrite ion $\left(\mathrm{NO}_{2}{ }^{-}\right)$. In November 2001, a sodium nitrite $\left(\mathrm{NaNO}_{2}\right)$ solution was added to the tank supernatant to correct the out-ofspecification condition. Mixing of the added $\mathrm{NaNO}_{2}$ with the sludge was expected to occur with time by natural process operating in the waste (Jo et al. 2002). The sampling event was performed to determine the effect the $\mathrm{NaNO}_{2}$ addition had on the waste, primarily the supernatant. Even though the supernatant was expected to be in specification, it was unlikely that the lower sludge layers were in specification because of

\footnotetext{
' ENRAF is a trademark of the ENRAF Corporation, Houston, Texas.
} 
the long mixing time predicted for dispersing the added chemicals in the sludge. The expectation that the sludge could remain out of compliance with the $\mathrm{AC} 5.15 \mathrm{NO}_{2}^{-}$limit for an extended time period provided justification for trying to understand the electrochemical corrosion behavior of this sludge material in contact with the carbon steel wall of the tank.

The sampling event that provided material for the corrosion potential tests was core 300 obtained from tank 241-AY-102 riser 057 between Apri1 24, 2002 and April 30, 2002. Analytical results from this sampling event are reported in Baker (2002). In general, the supernatant liquid was described as pale yellow and clear. The solids were described as brown and resembled a sludge. A waste physical profile developed for this core sample event is provided in Figure 2-1. The sludge material used in the corrosion potential testing was taken at the segment 13 location, i.e., at the tank bottom.

The results from the April 2002 core sample event indicate that the sludge chemistry now meets the limits of AC 5.15. This result was unexpected and was not known at the time when the corrosion potential testing was initiated. Chemical analysis of the interstitial liquids and centrifuged solids from segment 13 are provided in Appendix $\mathrm{C}$. The $\mathrm{pH}$ of the interstitial liquid was 12.1 , which corresponds to a hydroxide ion concentration of 0.018 moles per liter (M). The nitrite concentration was $2260 \mu \mathrm{g} / \mathrm{mL}(0.05 \underline{\mathrm{M}})$, and the nitrate concentration was less than $182 \mu \mathrm{g} / \mathrm{mL}(<0.003 \underline{\mathrm{M}})$. At these concentrations, the sludge chemistry falls just inside the lower AC 5.15 concentration limits of greater than or equal to $0.01 \underline{\mathrm{M}}$ for hydroxyl ion and greater than or equal to $0.011 \underline{\mathrm{M}}$ for nitrite ion.

Consequently, the corrosion potential measurements on the tank 241-AY-102 sludge serve to collaborate the in-specification condition of the sludge currently stored in the tank. The original objective to evaluate whether or not the type of carbon steel used in constructing the tank is susceptible to aggressive corrosion mechanisms when exposed to out-of-specification sludge material no longer applies. The value in the evaluation performed is that the applicability of the AC 5.15 lower compositional limits can be verified. 
Figure 2-1. Tank 241-AY-102 Core Profile

\section{AY-102 PMCS CORE PROFILE}

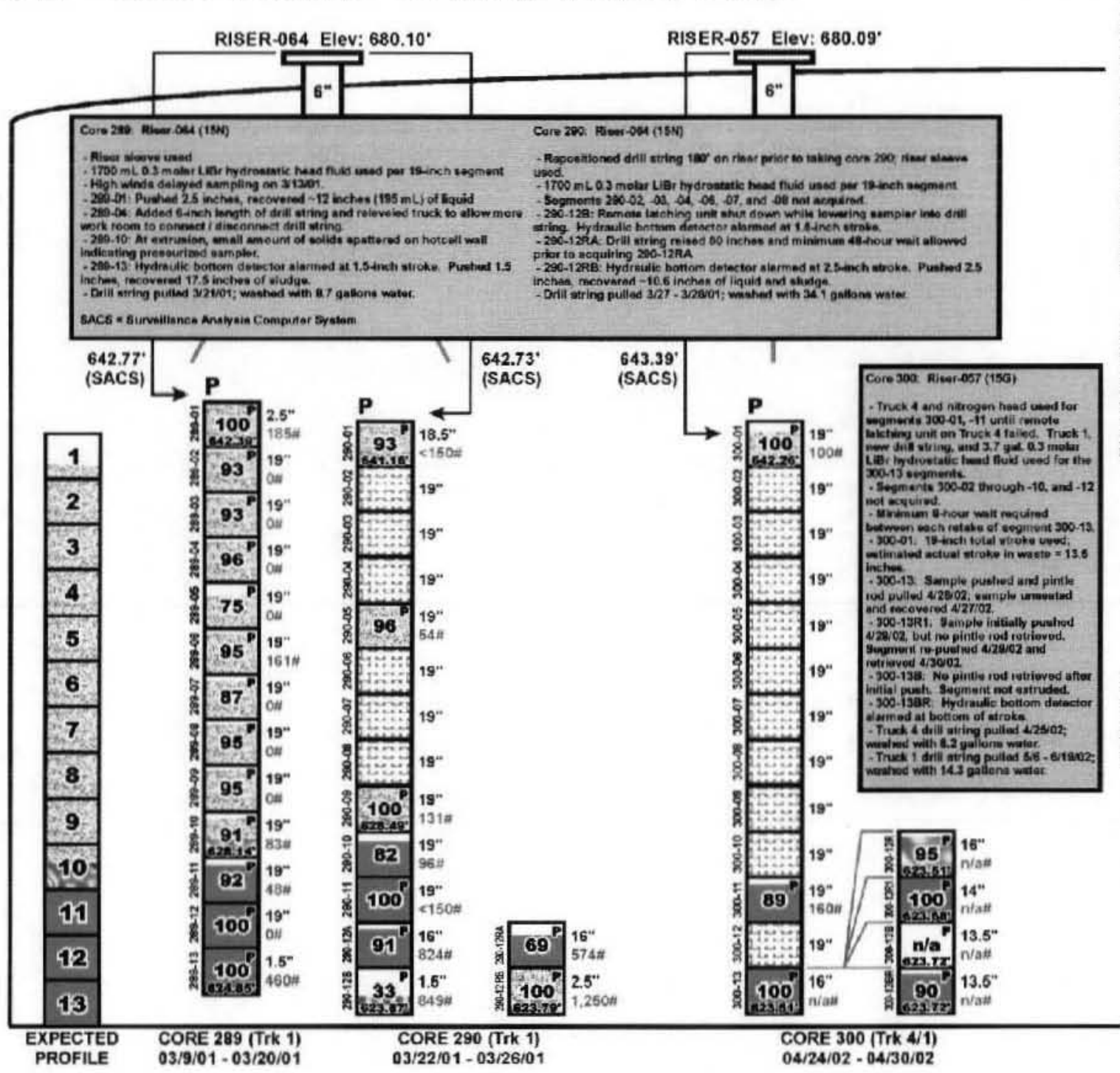

FILE: Core Profile 241AY102 C2Ba C290 C300.CRD DATE: 09/03/2002 FINAL

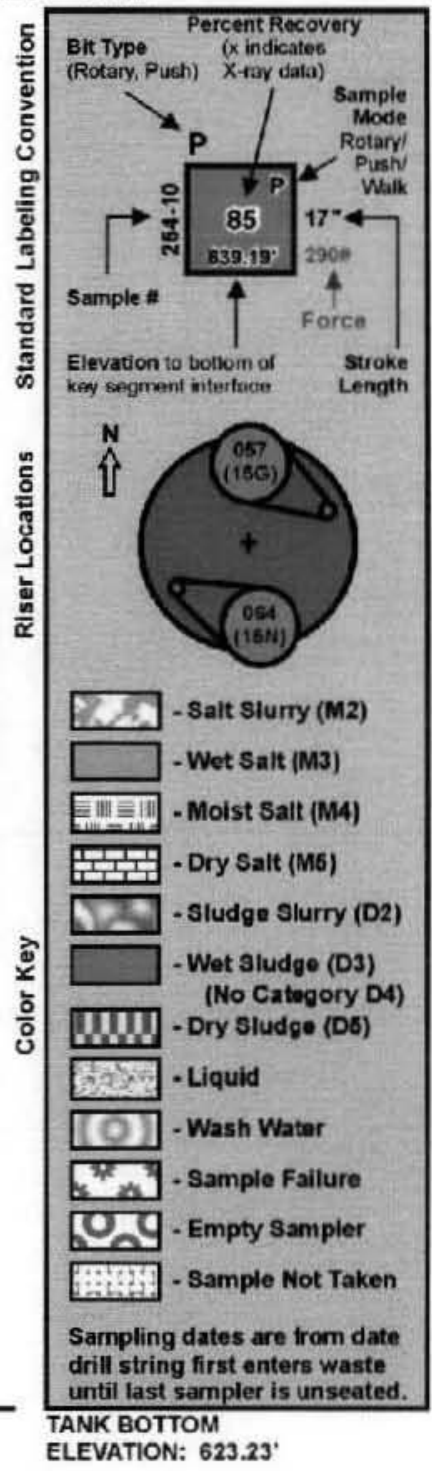




\subsection{BASIC ELECTROCHEMISTRY THEORY}

\subsubsection{General Relationship Between Corrosion and Electrochemistry}

Corrosion is a process involving electrochemical oxidation and reduction reactions. When a metal is immersed in a given solution, electrochemical reactions characteristic of the metal-solution interface occur at the surface of the metal causing the metal to corrode. These reactions create an electrochemical potential called the corrosion potential ( $E_{\mathrm{CORR}}$ ) or the open circuit potential measured in volts at the metal solution interface. The corrosion potential cannot be directly measured and must be determined by difference in potential with a known reference systcm. For iron in an acid solution two reactions are occurring. The iron metal is being oxidized (reaction in which an atom loses electrons) and hydrogen ions are being reduced (reaction in which an atom gains elcctrons) (Princeton Applied Research).

$$
\begin{aligned}
& \mathrm{Fe} \rightarrow \mathrm{Fe}^{+2}+2 \mathrm{e}^{-} \\
& 2 \mathrm{H}^{+}+2 \mathrm{e}^{-} \rightarrow \mathrm{H}_{2}
\end{aligned}
$$

At $E_{\text {CorR }}$, the ratc of oxidation is exactly equal to the rate of the reduction process and the system is in equilibrium. If a potential is imposed on the metal specimen, other than $\mathrm{E}_{\mathrm{CORR}}$, the specimen is polarized. This results in the oxidation or reduction reaction to become predominate at the metal surface, giving rise to a current (i). The current can be related to the rate of the electrochemical reactions. Potentials positive to $\mathrm{E}_{\mathrm{CORR}}$ will accelerate the oxidation reaction creating an anodic current (iox) and is displayed with a positive polarity. Potentials negative to $\mathrm{E}_{\mathrm{CORR}}$ will accelerate the reduction reaction and create a cathodic current $\left(\mathrm{i}_{\mathrm{RED}}\right)$ displayed with a negative polarity. Only the total current $\left(\mathrm{i}_{\text {Total }}\right)$ can be measured at the metal specimen. At $\mathrm{E}_{\mathrm{CORR}}$, the $\mathrm{i}_{\text {Total }}=\mathrm{i}_{\mathrm{RED}}+\mathrm{i}_{\mathrm{OX}}=0$ because the currents flow in opposite directions. By polarizing the specimen in a systematic manner and measuring the resulting current, the value of $i_{O x}$ or $i_{\text {RED }}$ can be determined at $\mathrm{E}_{\mathrm{CORR}}$. These polarization measurements are the basis for electrochemical corrosion studies. By polarizing the specimen, it is also possible to accelerate passivation, pitting, or other slow corrosion processes.

Most laboratory electrochemical corrosion tests are performed in a test cell containing the solution to be tested. The spccimen to be tested when immersed in the solution is called the working clectrodc. The reference electrode conlacts the solution by a bridge tube, which consists of a ceramic frit interface, and the test solution or other electrolyte.

Counter electrodes of graphite ur platinum are used to supply the current flowing at the working electrode during the test. The cell is configured to allow purging with an inert gas to remove oxygen that may impact the corrosion reactions. A potentiostat is used to control the potential difference between the reference and working electrode and measure the current between the working electrode and the counter electrode.

In potentiodynamic measurements, the electrode potential is slowly scanned $(0.1-10 \mathrm{mV} / \mathrm{sec})$ and the resulting current is measured. Scans within $\pm 25 \mathrm{mV}$ of Ecorr may be used in polarization resistance measurements to measure $R_{p}$, which is the 


\section{RPP 12077 Rev. 0}

resistance of the specimen to oxidation during polarization. This value may then be used in calculations to determine corrosion rates and the corrosion current (icorR). Tafel plots are performed over $\pm 250 \mathrm{mV}$ of $\mathrm{E}_{\mathrm{CORL}}$ and permit the estimation of Tafel constants that are used in the calculation of corrosion rales and current. Potentiodynamic scans over larger potential regions can identify passivation and transpassive areas of the corrosion system. Active-passive regions that can indicate potential for stress corrosion cracking can also be identified from the scan. Cyclic polarization where the potential is reversed to the negative (cathodic) direction may be used to evaluate the pitting tendencies of materials. The configuration of the cell and control of the potentiostat are used to perform different electrochemical measurements to understand the corrosion behavior of materials under varying conditions.

\subsubsection{Polarization Resistance}

The electrochemical measurement of polarization resistance is used to determine absolute corrosion rates, expressed in milli-inches per year (mpy). Polarization resistance measurements can be executed very rapidly. Excellent correlation may be made between corrosion rates obtained by polarization resistance and conventional weight-loss determinations. This technique is also referred to as "linear polarization."

As mentioned in Section 2.2.1, the polarization resistance measurement is performed by scanning through a potential range, which is very close to the corrosion potential ( $\left.\mathrm{E}_{\mathrm{CORR}}\right)$, generally $\pm 25 \mathrm{mV}$ versus $\mathrm{E}_{\mathrm{CORR}}$. The corrosion current $\mathrm{i}_{\mathrm{COR} \text {, }}$ is related to the response of the scanning potential versus current through the equation:

$$
\Delta \mathrm{E} / \Delta \mathrm{i}=\left(\beta_{\mathrm{A}} \beta_{\mathrm{C}}\right) /\left[2.3\left(\mathrm{i}_{\mathrm{CORR}}\right)\left(\beta_{\mathrm{A}}+\beta_{\mathrm{C}}\right)\right]
$$

Where:

$\Delta \mathrm{E} / \Delta \mathrm{I}=$ The slope of the polarization resistance plot. $\Delta \mathrm{E}$ has units of volts and $\Delta \mathrm{i}$ has units of microamps $(\mu \mathrm{A})$. The slope has units of resistance, hence, polarization resistance.

$\beta_{\mathrm{A}}, \beta_{\mathrm{C}}=$ Anodic and cathodic Tafel constants. These must be determined from a Tufel Plot (see Section 2.2.3). The constants have units of volts/decade of current (may be expressed as $\mathrm{mV} /$ decade also).

$\mathrm{i}_{\mathrm{CORR}}=$ Corrosion current, $\mu \mathrm{A}$.

A thcorctical background for polarization resistance measurements emanated from the work of Stern and Geary (1957). Basically, in a corroding system, two co-existing electrochemical reactions are present.

$$
\mathrm{M}^{+}+\mathrm{e}^{*} \leftrightarrow \mathrm{M} \quad \text { (Corroding metal) }
$$




$$
\mathrm{Z}^{+}+\mathrm{e}^{-} \leftrightarrow \mathrm{Z} \quad \text { (Chcmical species in solution) }
$$

The equilibrium potentials of the couples in Equation 2 and Equation 3 are labeled $\mathrm{E}_{\mathrm{EQ}, \mathrm{M}}$ and $E_{\mathrm{EQZ}}$, respectively. When the corrosion potential is sufficiently removed from $\mathrm{E}_{\mathrm{EQ} . \mathrm{M}}$ and $\mathrm{E}_{\mathrm{EQZ}}$, the rate of reduction of $\mathrm{M}^{+}$becomes insignificant compared to the rate of oxidation of $\mathrm{M}$ and likewise, the rate of oxidation of $\mathrm{Z}$ becomes insignificant with respect to the rate of reduction of $Z^{+}$. The corrosion potential, therefore, is the potential at which the rate of oxidation of $M$ (defined by current $i_{O, M}$ ) is equal to the rate of reduction of $Z$ (defined by the current $i_{R, Z}$ ). Since the net current is the difference between the oxidation and reduction currents, the current measured (i $i_{\text {MEAS }}$ ) with an external device will be zero.

$$
\mathrm{i}_{\mathrm{MEAS}}=\mathrm{i}_{\mathrm{OM}}-\mathrm{i}_{\mathrm{R}, \mathrm{Z}}=0 \text { at } \mathrm{E}_{\mathrm{CORR}}
$$

In order to calculate the corrosion rate, $\mathrm{i}_{\text {CORR }}$ must be determined.

When a potential is imposed on the metal specimen from an external voltage source, such as a potentiostal, a current will pass according to the following equation:

$$
\mathrm{i}_{\text {MEAS }}=\mathrm{i}_{\mathrm{O} . \mathrm{M}}-\mathrm{i}_{\mathrm{R}, 7}
$$

The anodic and cathodic currents obey the Tafel equation (see Section 2.2.3):

$$
\begin{aligned}
& \eta=\beta_{\Lambda} \log \left(i_{O, M} / i_{C O R R}\right) \\
& \eta=-\beta_{C} \log \left(i_{R, Z} / i_{C O R R}\right)
\end{aligned}
$$

Where:

$$
\begin{aligned}
\eta= & \text { The overvoltage, the difference between the potential imposed on the } \\
& \text { specimen and the corrosion potential, or } E_{\mathrm{APP}}-E_{\mathrm{CORR}} \text {. }
\end{aligned}
$$

Equations 6 and 7 are rearranged to yield:

$$
\begin{aligned}
& \log \left(i_{O, M} / i_{C O R R}\right)=\eta / \beta_{A} \\
& \log \left(i_{R, Z} / i_{C O R R}\right)=-\eta / \beta_{C}
\end{aligned}
$$

Taking the transform of Equations 8 and 9 yields:

$$
\begin{aligned}
& 10^{\eta / \beta_{A}}=i_{O, M} / i_{C O R R} \\
& 10^{-\eta / \beta_{C}}=i_{R, Z} / i_{C O R R}
\end{aligned}
$$


Now, substituting Equations 10 and 11 into Equation 4, yields:

$$
i_{\text {MEAS }}=i_{\text {CORR }}\left(10^{\eta / \beta_{A}}-10^{-\eta} i_{C}\right)
$$

Since using a power series may approximate $10^{x}$, and if $x$ is a small value, then the third and later terms may be neglected without significant error. Therefore, substituting the term $\eta / \beta_{A}$ for $x$, the power series collapses into:

$$
\begin{aligned}
& 10^{\eta / \beta_{A}}=1+2.3 \eta / \beta_{A} \\
& 10^{-n / \beta_{C}}=1-2.3 \eta / \beta_{C}
\end{aligned}
$$

Substituting Equations 13 and 14 into Equation 12 and simplifying yields:

$$
\mathrm{i}_{\mathrm{MEAS}}=2.3 \mathrm{i}_{\mathrm{CORR}} \eta\left(\beta_{\mathrm{A}}+\beta_{\mathrm{C}} / \beta_{\mathrm{A}} \beta_{\mathrm{C}}\right)
$$

Rearranging to solve for polarization resistance yields Equation 16, which is identical to Equation 1:

$$
\eta / \mathrm{i}_{\text {MEAS }}=\beta_{\mathrm{A}} \beta_{\mathrm{C}} /\left(2.3 \mathrm{i}_{\mathrm{CORR}}\left(\beta_{\mathrm{A}}+\beta_{\mathrm{C}}\right)\right)
$$

For the most accurate results, the Tafel constants, $\beta_{\mathrm{A}}$ and $\beta_{\mathrm{C}}$, must be independently determined from a Tafel Plot.

\subsubsection{Tafel Plot}

A Tafel Plot is performed on a metal specimen by polarizing the specimen $250 \mathrm{mV}$ cathodically and $250 \mathrm{mV}$ anodically from the corrosion potential ( $\left.\mathrm{E}_{\mathrm{CORR}}\right)$ and measuring the associated current. Figure 2-2 depicts a Tafel Plot. The convergence of the cathodic (lower) and anodic (upper) polarization curves (i.e., the spike on the Figure 2-2 curve) represents $E_{\text {CORR. The intersection of the lines tangent to the cathodic and anodic Tafel }}$ slopes are at $i_{C O R R}$ as shown in the figure. 
RPP 12077 Rev. 0

Figure 2-2. Example of Tafel Plot

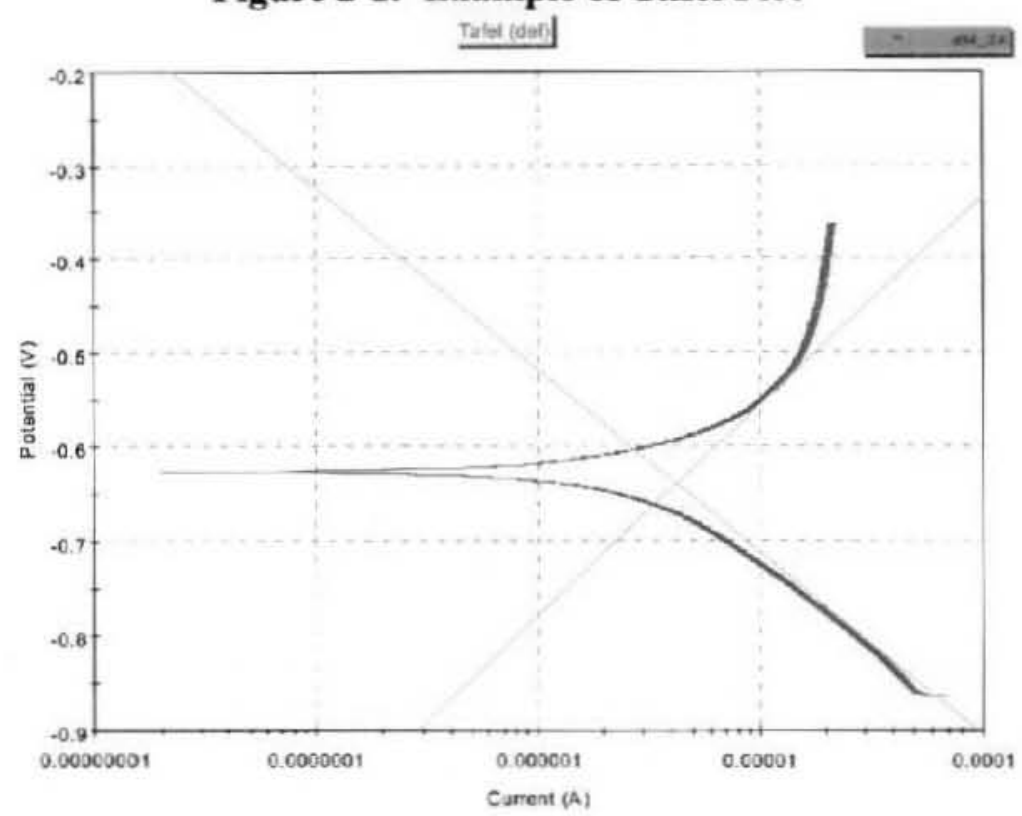

The anodic or cathodic Tafel Plots are described by the Tafel equation.

$$
\eta=\beta \log \left(i / i_{\text {CORR }}\right)
$$

Where

$\eta=$ The overvoltage, the difference between the potential of the specimen and the corrosion potential.

$\beta=$ Tafel constant.

$\mathrm{i}_{\mathrm{CORR}}=$ Corrosion current, $\mu \mathrm{A}$.

$\mathrm{i}=$ Current at overvoltage $\eta, \mu \mathrm{A}$.

Rearrangement of Equation 17 yields:

$$
\eta=\beta\left(\log i-\log i_{\text {CORR }}\right)
$$

Equation 18 is in the form of a straight line, $y=m x+b$. A plot of $\eta$ versus $\log i$ is a straight line with slope $\beta$. Tafel constants must be calculated from the cathodic and anodic portions of the Tafel Plot. The units of the Tafel constant are either in $\mathrm{mV} / \mathrm{decade}$ of current or V/decade of current. A decade of current is one order of magnitude. 


\subsubsection{Corrosion Rate Calculation}

According to Faraday's Law:

$$
\mathrm{Q}=(\mathrm{nFW}) / \mathrm{M}
$$

Where

$\mathrm{Q}=$ Coulombs

$\mathrm{n}=$ The number of electrons involved in the electrochemical reaction.

$\mathrm{F}=$ The Faraday constant with a value of 96,487 coulombs.

$\mathrm{W}=$ The weight of the electroactive species.

$\mathrm{M}=$ The molecular weight of the electroactive species.

Rearranging Equation 19,

$$
\mathrm{W}=\mathrm{QM} / \mathrm{nF},
$$

and since equivalent weight $\mathrm{E}_{\mathrm{w}}=\mathrm{M} / \mathrm{n}$, then

$$
\mathrm{W}=\left(\mathrm{QE}_{\mathrm{wt}}\right) / \mathrm{F}
$$

Since $Q=i$ * t from Faraday's Law,

$$
W=\left(i * t * E_{w t}\right) / F
$$

Where

$$
\begin{aligned}
& i=\text { current } \\
& t=\text { time }
\end{aligned}
$$

The term W/t is the corrosion rate (C.R.) in grams / second. It is convenient and traditional to express corrosion rate as milli-inches per year (mpy). These units provide an indication of penetration.

Dividing Equation 20 by the electrode area (A) and the material's density (d) gives

$$
\text { C.R. }(\mathrm{cm} / \mathrm{sec})=\left(\mathrm{i} * \mathrm{E}_{\mathrm{wt}} / \mathrm{dFA}\right)
$$

Converting the seconds to years and centimeters to milli-inches, the Faraday (amp $-\mathrm{sec} /$ eq) to microamps yields.

$$
\text { C.R. }(m p y)=\left(i * E_{w 1} * 31.6 * 10^{6} * 10^{3}\right) /\left(d F A * 2.5 * 10^{6}\right)
$$

Expressing the terms $\mathrm{i} / \mathrm{A}$ as current density and combining all the constants yields

$$
\text { C.R. }(m p y)=\left(0.13 * i_{\text {CORR }} * E_{\mathrm{wil}}\right) / d
$$


RPP 12077 Rev. 0

Where $\mathrm{i}_{\mathrm{CORR}}=$ Corrosion current density, $\mu \mathrm{A} / \mathrm{cm}^{2}$.

$\mathrm{E}_{\mathrm{m}}=$ Equivalent weight of the corroding species, in grams.

$\mathrm{d}=$ Density of the corroding species, $\mathrm{g} / \mathrm{cm}^{3}$.

Equation 23 is used to calculate the corrosion rate directly from $i_{\text {CoRR, which is }}$ determined from the Tafel Plot after a potentiodynamic scan.

\subsection{EQUIPMENT DESCRIPTION}

\subsection{EXTRUSION PLATFORM DESCRIPTION}

Extrusions of core segment samples are done in the Fluor Hanford, Inc., Analytical Services' 11 A hot cell at 222-S Laboratory. Normally a core segment is extruded from the sampler in a horizontal configuration. The waste sample falls onto an open-top tray, which is exposed to ventilation air circulating in the hot cell, as it is pushed out the end of the sampler. Any liquid drains through an opening in the bottom of the tray at one end and is collected in a sample jar. Solids that remain on the tray are spooned into a different sample jar using a spatula-like tool.

The requirement for anaerobic extrusion necessitated an approach that was outside the routine for the laboratory. A specially designed extrusion platform for performing the anaerobic extrusion is described below.

\subsubsection{Vertical Configuration of Sampler}

In order to anaerobically extrude a sludge segment, the decision was made to place the sampler in a vertical configuration, normal to the plane of the opening of the sample jar (which also served as the electrochemical cell). In this manner, the sludge sample could be extruded directly into the test cell, thereby eliminating the need to transfer the sludge at a later time and risk exposure to oxygen in the ventilation air. To accomplish this, an extrusion platform was designed and testing conducted to demonstrate its performance in extruding material under anaerobic conditions (discussed below). Once a sampler was positioned onto the extrusion platform, it would be held in place with one of the hot cell remote-operated manipulators. A second manipulator was used to extrude the sample following Laboratory Operation Procedure 160-104 (LO-160-104).

The entire extrusion operation would be carried out under a flow of argon gas (discussed below) to eliminate exposure of the test material to oxygen to the extent practicable. 


\subsubsection{Extrusion Platform}

In order to accommodate the sampler in a vertical configuration and to ensure oxygen was depleted in the electrochemical cell before and during sample extrusion, an extrusion platform was designed and fabricated by $222 \mathrm{~S}$ Laboratory crafts.

Figure 3-1 through Figure 3-6 show the extrusion platform assembly from the bottom plate through the top sampler holding plate. Figure 3-1 shows the bottom plate of the extrusion platform. A cutout was made in the bottom plate to accommodate the electrochemical cell (see Figure 3-2). Note the leveling ability of the bottom plate using the allthread bolts at each corner. Figure 3-3 shows the middle plate placed atop the allthread corners. The center opening is positioned directly above the opening of the sample jar/electrochemical cell and is oversized slightly to allow the test cell to be capped off in-place after completing an extrusion of sample material. A top plate is then positioned with a small diameter opening at the center that aligns with the sample jar/electrochemical cell directly below (see Figure 3-4). The center opening of the top plate is machined to mate with the sampler when held in a vertical position. In addition, a tab at the far edge of the top plate was added to allow handling with a hot cell manipulator. The final extrusion platform assembly is shown in Figure 3-5 with its Plexiglas $(\mathbb{B})^{2}$ enclosure in place. A barbed nipple projects through the Plexiglas $₫$ wall for connecting with an argon gas supply. Figure 3-6 depicts how the sampler will mate up with the extrusion platform when extruding sample material in the hot cell.

Figure 3-1. Bottom Plate of Extrusion Platform

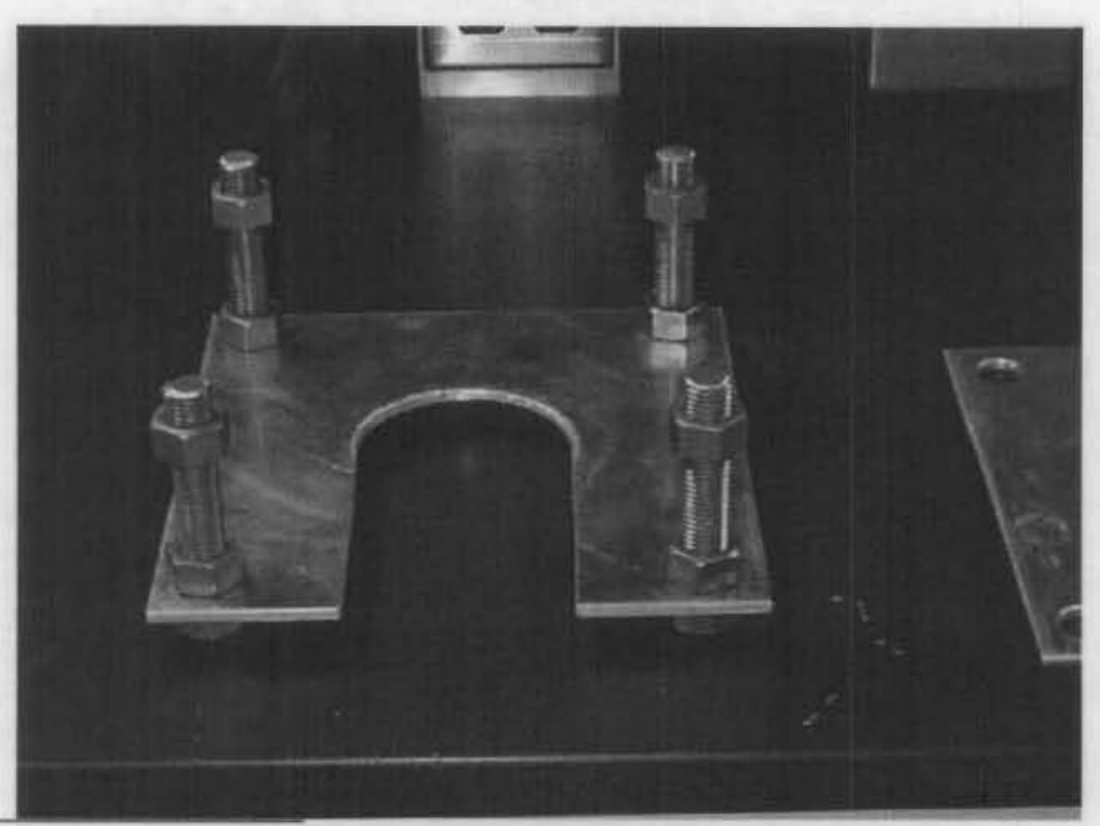

\footnotetext{
${ }^{2}$ Plexiglas is a registered trademark of the Rohm and Haas Company, 100 Independence Mall West, Philadelphia, Pennsylvania.
} 
RPP 12077 Rev. 0

Figure 3-2. Electrochemical Cell in Position

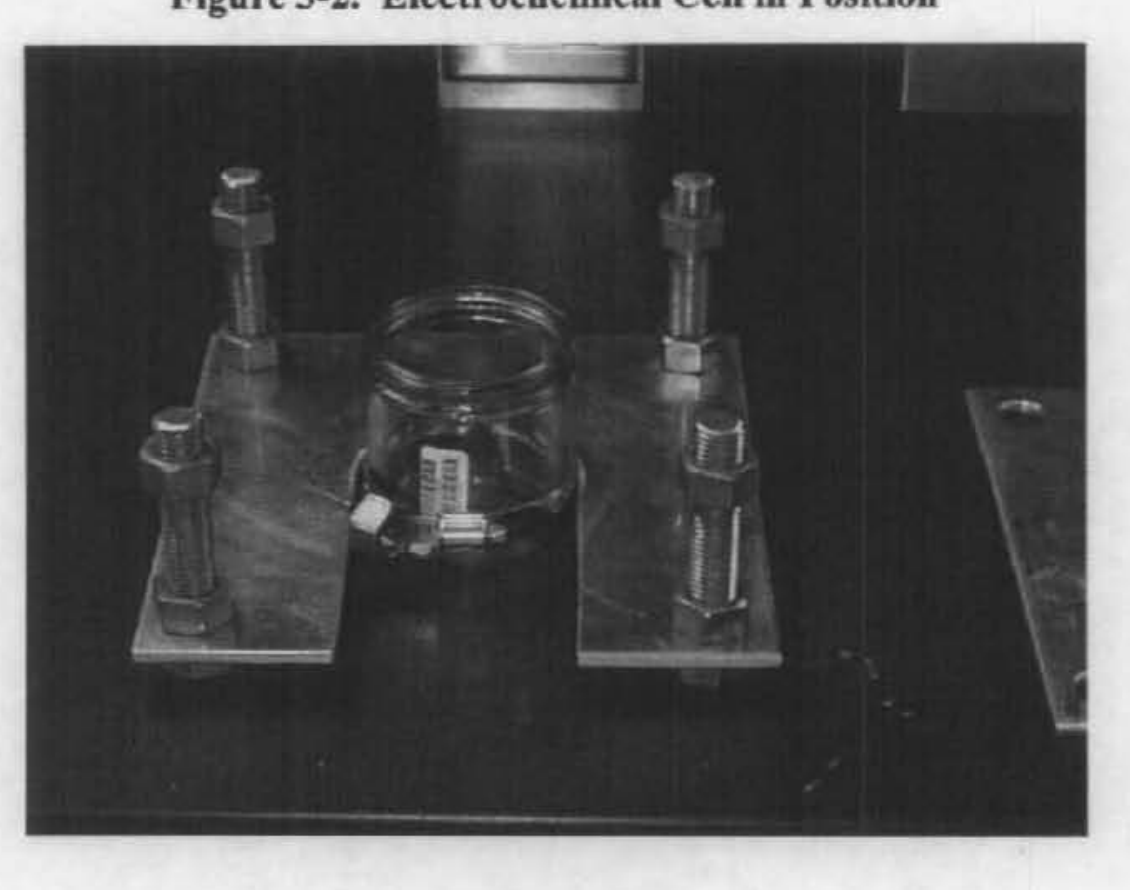

Figure 3-3. Middle Plate in Position
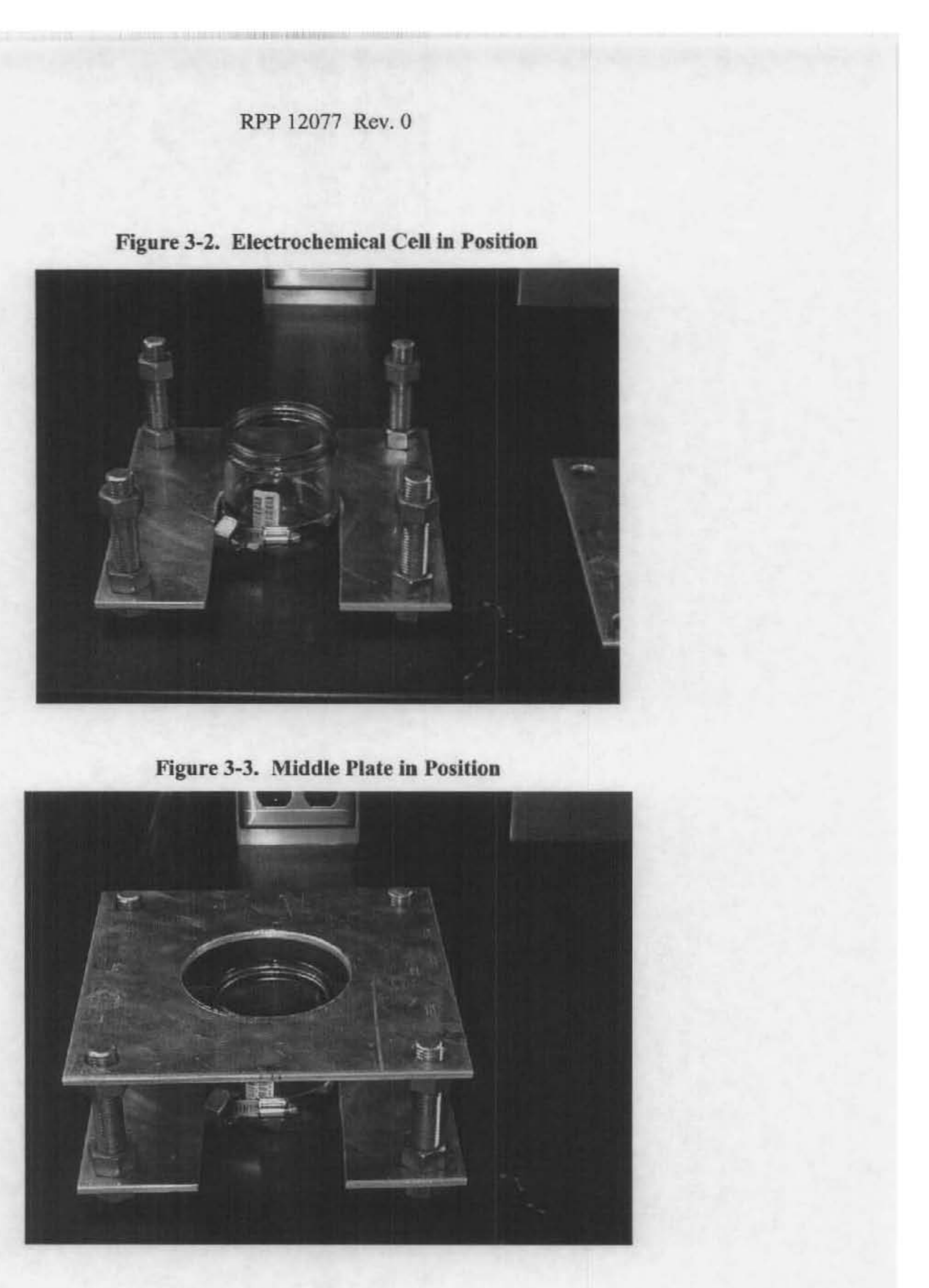
Figure 3-4. Top Plate in Position

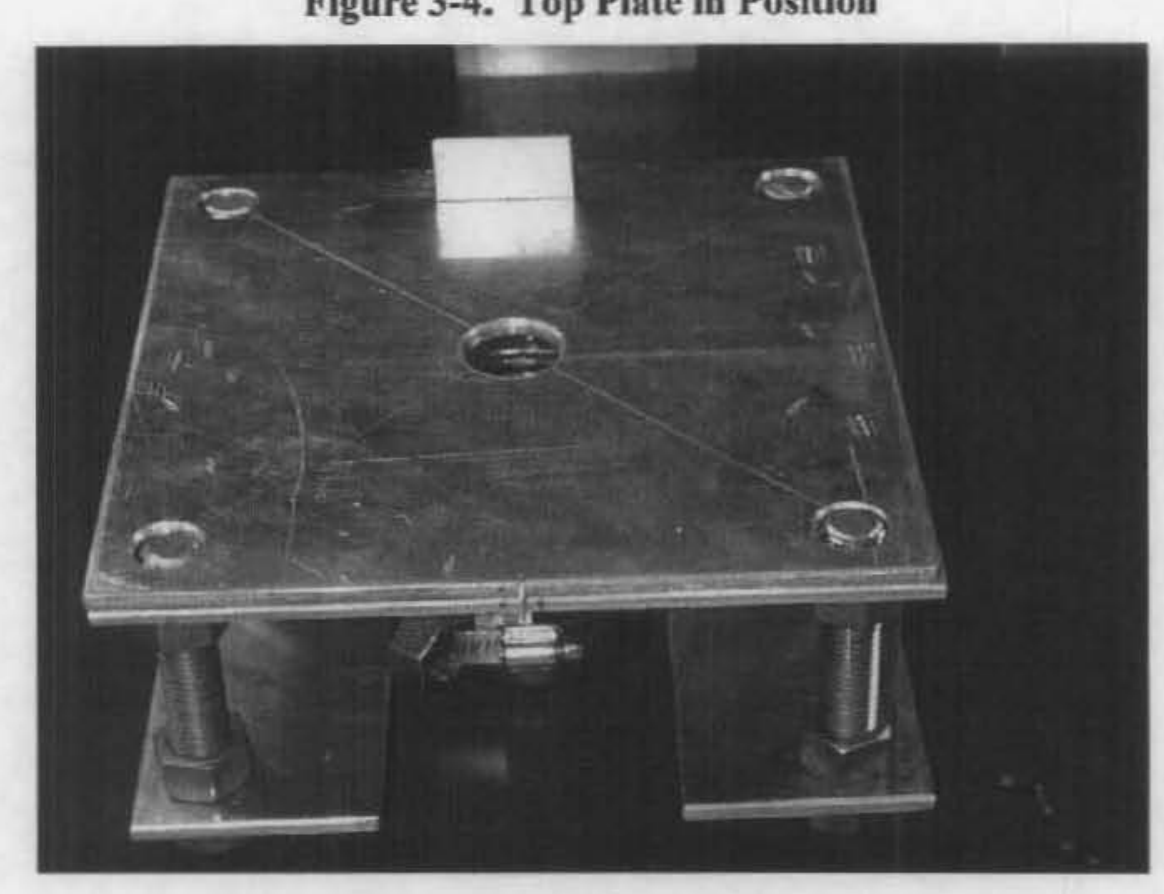

Figure 3-5. Extrusion Platform with Plexiglas $(\mathbb{B})$ Enclosure

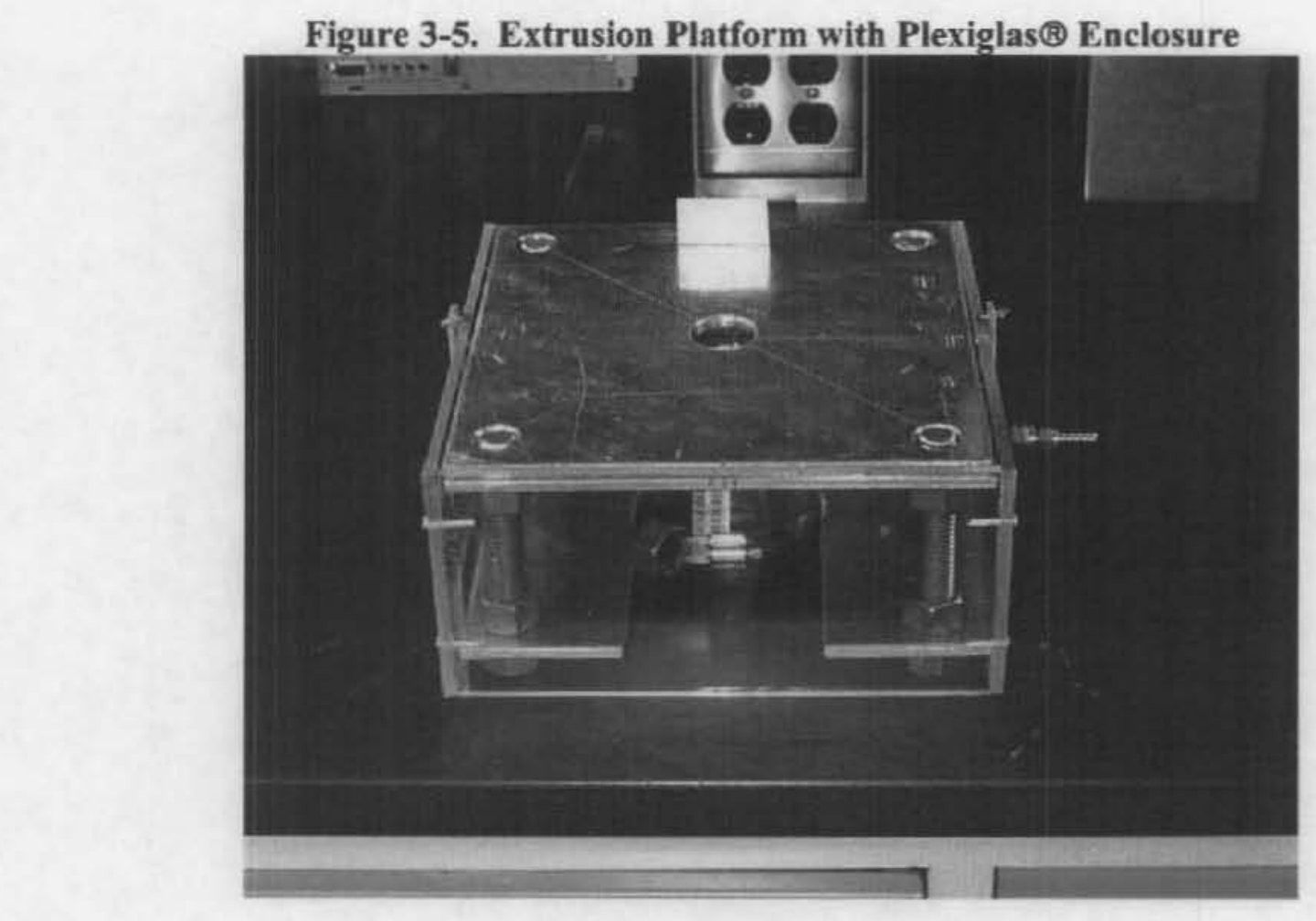

Page 28 of 99 of 10130772
RPP 12077 Rev. 0

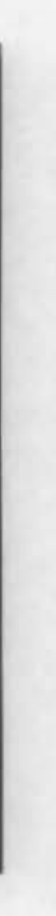

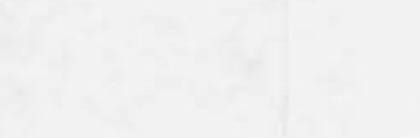

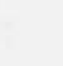
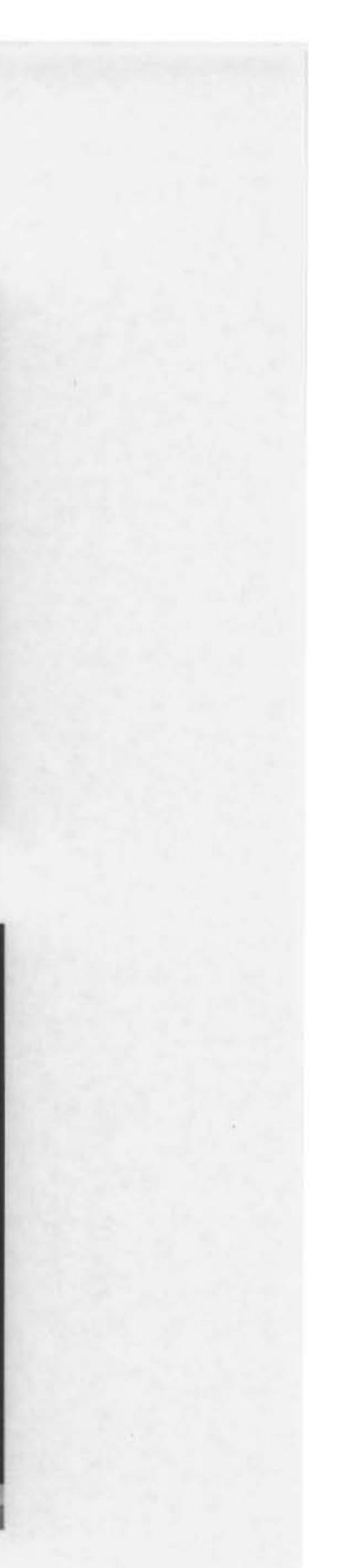
Figure 3-6. Complete Extrusion Platform with Sampler in Position

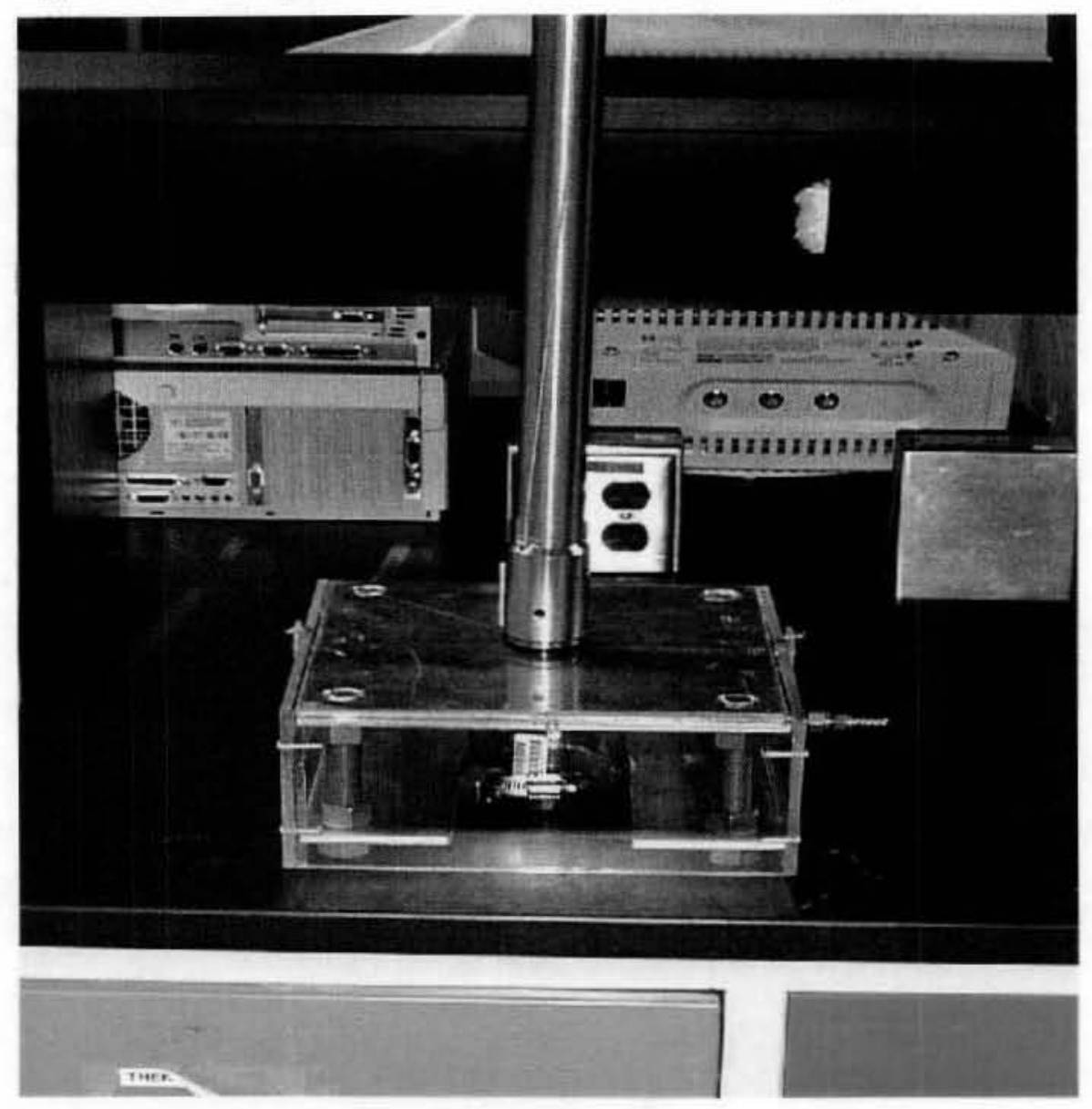

The extrusion platform in the configuration shown in Figure 3-5 was tested for efficacy in retaining anaerobic conditions (see Section 3.1.3). An argon gas supply was introduced through the barbed nipple on the side of the Plexiglas $($ enclosure.

Purging the extrusion platform enclosure in this configuration did not lend itself to attaining oxygen depletion to less than 0.2 percent. Therefore, the Plexiglas $\circledast$ enclosure was sealed at its bottom edge to further isolate the chambers from the atmosphere. In addition, two modifications were initiated as shown in Figure 3-7 and Figure 3-8. Figure 3-7 is a photograph of the top plate with directionally drilled openings into the enclosure directly above the test cell. Figure 3-8 shows a collar of polypropylene that is configured to fit snugly around the sampler and is fitted with a nipple for introducing argon gas. The inner diameter of the collar encircles the directional openings in the top plate. In this manner, the volume of the sample jar/electrochemical cell is purged directly with the argon gas flowing through the directional openings in the top plate. Testing of the final extrusion platform configuration is discussed in Section 3.1.3. 
Figure 3-7. Directional Openings in Top Plate of Extrusion Platform

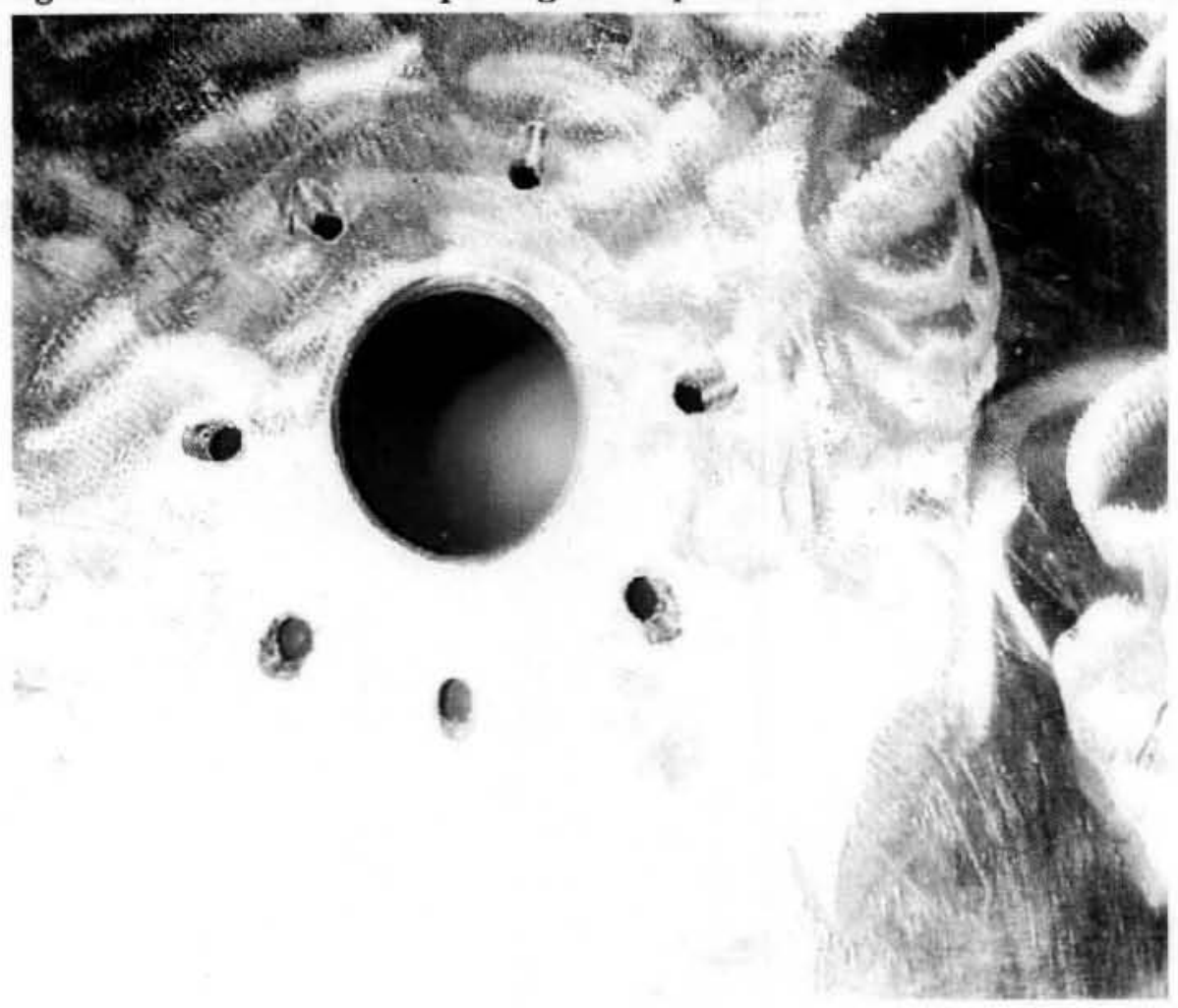

Figure 3-8. Sampler Collar with Argon Gas Inlet

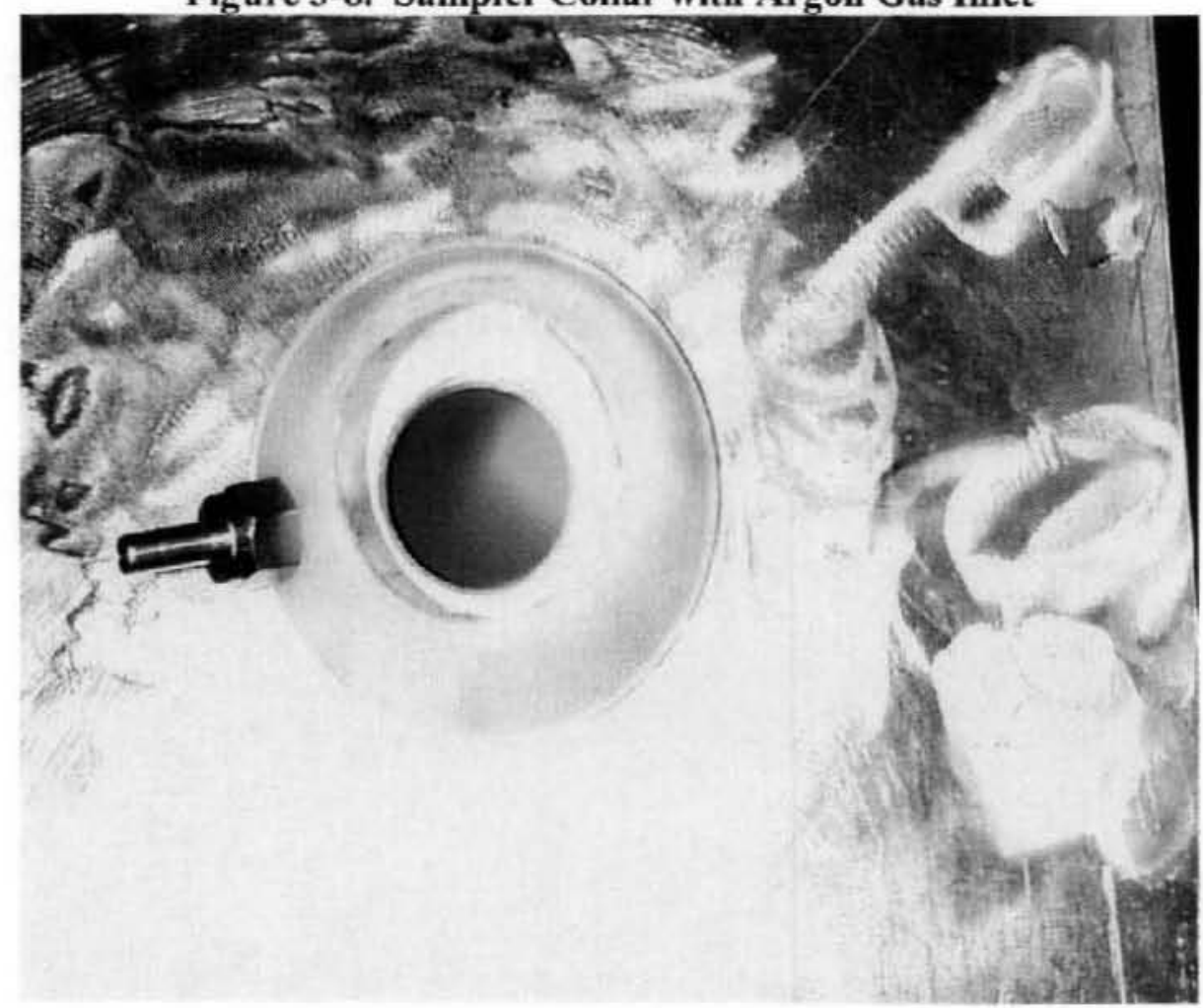




\subsubsection{Oxygen Depletion Inside Extrusion Platform}

To confirm that the design of the extrusion platform was compatible with anaerobic extrusion, several trials were carried out in 222-SA Laboratory (non-radiation laboratory). A Matheson Tri-Gas Oxygen Deficiency Monitor, Model 8061, was used to monitor oxygen concentration within the enclosed volume of the platform for various test arrangements (see Section 3.3).

A sampler with the argon purge collar fitted to its end was positioned vertically on the extrusion platform with the Plexiglas ${ }^{\circledR}$ enclosure in place. Argon was introduced into the apparatus through either the collar or the side port with the oxygen meter reading taken either inside or outside the sample jar/electrochemical cell. Table 3-1 gives the test location of the oxygen sensor relative to the introduction point of the argon gas. The response of oxygen to the various flow configurations is shown in Figure 3-9.

Table 3-1. Extrusion Platform Argon Purge Test Arrangements

\begin{tabular}{|c|c|}
\hline Oxygen Sensor Placement & Argon Gas Introduction \\
\hline Outside sample jar/electrochemical cell & Plexiglas Side Port \\
\hline Outside sample jar/electrochemical cell & Sampler Collar \\
\hline Inside sample jar/electrochemical cell & Plexiglas Side Port \\
\hline Inside sample jar/electrochemical cell & Sampler Collar \\
\hline
\end{tabular}


Figure 3-9. Extrusion Platform Enclosure Oxygen Depletion as a Function of Time

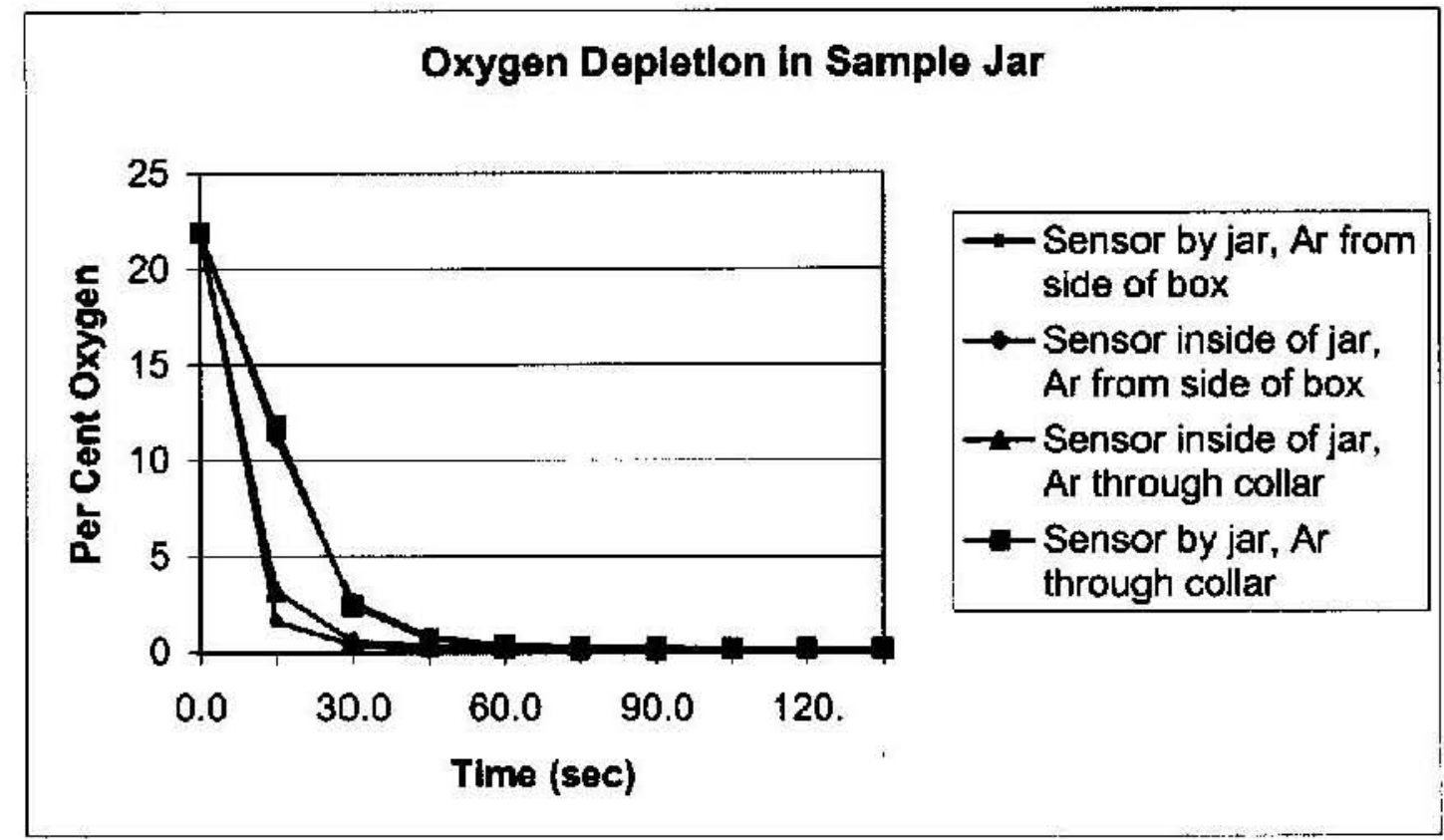

At 60 seconds, the oxygen meter registered 0.1 percent to 0.0 percent, irrespective of oxygen sensor placement or argon introduction in the extrusion platform enclosure. Therefore, a purge of the extrusion platform enclosure with argon gas for 120 seconds prior to beginning an extrusion of tank 241-AY-102 sludge was selected to ensure anaerobic conditions during the extrusion.

\subsection{REMOTE ELECTROCHEMICAL CELL DESCRIPTION}

The requirement to extrude and keep the tank 241-AY-102 sludge sample under anaerobic conditions, as well as the sludge essentially being a "solid" rather than a liquid, presented a unique set of problems for conducting the corrosion potential testing. In order to minimize sample handling, the sample jar used to perform the extrusion would perform double duty, in that it would also serve as the electrochemical cell. The efficacy of this approach was confirmed using the ASTM G5-94 method (see Section 4.1).

The sample jar/electrochemical cell used to contain the extruded tank 241-AY-102 sample was a standard laboratory jar in the Fluor Hanford, Inc., 222-\$ Laboratory inventory. The jar is an I-Chem product measuring $8 \mathrm{~cm}$ in diameter and $9 \mathrm{~cm}$ in height. A size 4-rubber stopper was machined to fit snugly into the jar opening. The stopper was also configured to accept the reference electrode, working electrode, counter electrodes (platinum), thermocouple lead, and argon gas ports (inlet and outlet). In the case of the ASTM G5-94 method, the top was configured to accept the reference electrode, working electrode, counter electrodes (platinum), argon sparge port, and vent hole. 


\subsubsection{Configuration of Electrochemical Cell Cover}

Figure 3-10 shows the plan view of the electrochemical corrosion cell cover (a size 4rubber stopper).

Figure 3-10. Plan View of Electrochemical Cell Cover

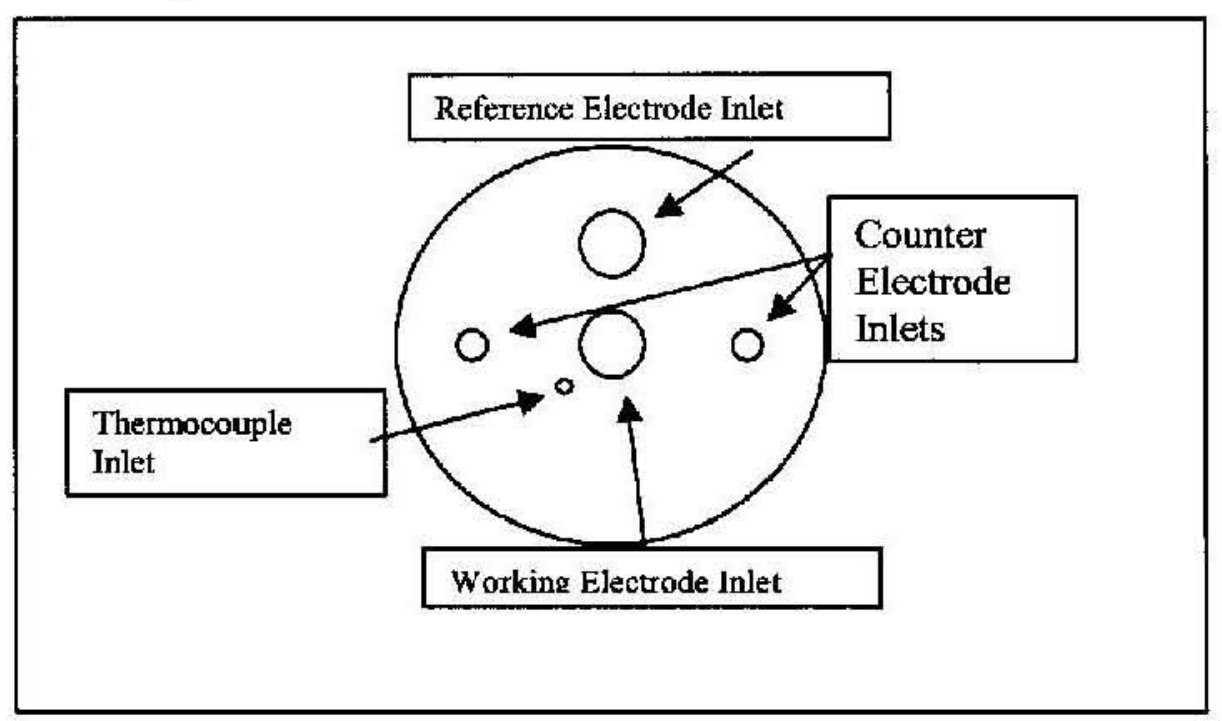

The openings for the working electrode and the reference electrode accommodated a size 2-rubber stopper. This allowed ease of remote replacement of the working electrode using hot cell manipulators. The reference electrode was protected with a salt bridge using a Luggin with a ceramic tip. (A Luggin is a salt bridge that protects the reference electrode.) The ability to easily remove the reference electrode/Luggin during the time the working electrode was achieving open-circuit potential ( $\mathrm{E}_{\mathrm{CORR}}$ ) aided in ensuring that the ceramic Luggin tip would not suffer from the harsh sludge environment. When either the reference/Luggin or the working electrode was removed, a blank size 2-rubber stopper was placed in the cover to block the opening, thereby maintaining the argon gas purge.

\subsubsection{Electrode Configuration}

The electrode configuration mimicked that of the standard ASTM G5-94 test cell. The working electrode was concentrically located, the reference electrode was in close proximity to the working electrode, the counter electrodes were insulated using a sealed glass tube the depth of the rubber stopper and diametrically opposed (Figure 3-11). The letters in Figure 3-11 identify the following components.

A $=$ Working electrode

$B=$ Luggin/Reference electrode

$\mathrm{C}=$ Glass frit for argon gas sparge (for ASTM G5-94 method testing only)

$\mathrm{D}=$ Glass insulated platinum electrodes (i.e., counter electrodes). 


\subsubsection{Working and Counter Electrodes}

The working electrodes (test specimen) were purchased from Metal Samples, Mumford, Alabama. For the ASTM G5-94 test method, a cylindrical coupon of A430 stainless steel (SS) was used. For tank 241-AY-102 simulant waste tests and tests of actual tank sludge, A515 grade 60 carbon steel was used. The A515 grade 60 carbon steel is of the type similar to that used in the tank's construction. The counter electrodes were platinum coil, purchased from Alfa Aesar, Wand Hill, Massachusetts. The wetted surface area for the working electrode is $5.64 \mathrm{~cm}^{2}$. Surface area for each of the counter electrodes (that part submerged in the sludge) is $14 \mathrm{~cm}^{2}$.

Figure 3-11. 500-mL Electrochemical Cell Cover

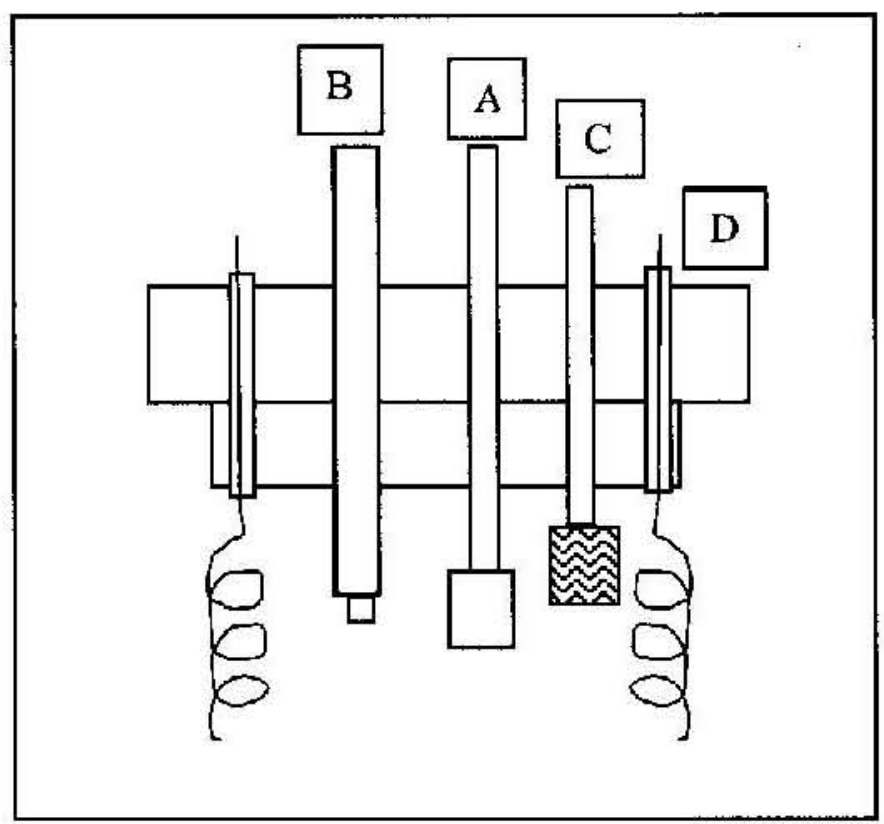

\subsection{INSTRUMENTATION DESCRIPTION}

\subsubsection{Potentiostat}

During the course of the project, two instruments were used to carry out electrochemical studies on tank 241-AY-102 sludge, i.e., PAR 273 and PARSTAT 2263. These instruments are the potentiostats needed to drive the corrosion potential tests and collect the polarization scan data. Princeton Applied Research, Oak Ridge, Tennessee, manufactured both instruments. The first, a loaner instrument, a PAR 273 potentiostat/galvanostat, was employed in the testing because of the long lead-time for delivery of a PARSTAT 2263, the purchased instrument. The PAR 273 was originally to 
be used for the entire tank 241-AY-102 electrochemical corrosion studies. However, the PAR 273 experienced electronic problems during the course of the testing and was replaced with the PARSTAT 2263 after verifying its operability by performing the ASTM G5-94 test method.

The PAR 273 is controlled by proprietary software through a general purpose interface bus (GPIB), Institute of Electrical and Electronics Engineers (IEEE-488). The controlling software is the SoftCore III Corrosion Measurement Software using the PARCalc analysis routine for corrosion yielding Tafel slopes, $E_{C O R R}$ and $i_{C O R R}$ values, and chi square goodness of fit data.

The instrument purchased specifically for the project, a PARSTAT 2263 (Princeton Applied Research, Oak Ridge, Tennessee), is a new generation of Princeton Applied Research potentiostat/galvanostat instruments. The PARSTAT 2263 is also controlled by proprietary software through a universal serial bus (USB). The controlling software is the PARSAT Power Suite, which allows for corrosion calculations via the PARCalc analysis routine for corrosion yielding $T$ afel slopes, $\mathrm{E}_{\text {CORR }}$ and $\mathrm{i}_{\text {CORR }}$ values, and chi square goodness of fit data.

\subsubsection{Oxygen Monitor}

A Matheson Tri-Gas Oxygen Deficiency Monitor, Model 8061, was used to monitor oxygen concentration within the enclosed volume of the extrusion platform during testing (see Section 3.1.3) and during actual extrusions of tank 241-AY-102 core segment sludge samples in the 222-S Laboratory 11A hot cell (see Section 5.1).

The Model 8061 uses a galvanic cell consisting of a noble metal electrode and a base metal electrode in an aqueous electrolyte solution. The output of the cell is proportional to the oxygen concentration. A thermistor is used to compensate for temperature changes. The Model 8061 has an accuracy of \pm 3 percent with a 2 to 4 second response time, a range of 0 to 40 percent oxygen concentration, and a temperature operating range of 0 to $45^{\circ} \mathrm{C}$.

The oxygen meter was employed under ambient atmospheric conditions with only the extrusion platform, where it was not subjected to high bumidity or water vapor. Once a core segment was extruded, the assumption was made that the anaerobic condition of the sample material would be maintained by ensuring the headspace of the sample jar $t$ electrochemical cell was continuously purged by argon gas at all times. 
RPP 12077 Rev. 0

\subsection{METHOD VERIFICATION TESTING}

\subsection{ASTM G5-94 METHOD TESTING}

The ASTM G5-94 method was used to confirm that the electrochemical cell arrangement and measurement instrumentation were performing properly during the testing program.

Because of the long delivery time for the vendor to fulfill the purchase request with the PARSTAT 2263 instrument, a loaner instrument (PAR 273) was made available to 222-S Laboratory. The PAR 273 was initially set up in 222-SA Laboratory to conduct testing of the ASTM G5-94. Testing of tank 241-AY-102 sludge in a hot cell environment was initiated only after preliminary tests successfully demonstrated that the procedures and equipment gave quality potentiodynamic scans.

The PAR 273 instrument was performance tested by performing the ASTM G5-94 method, which measures the current density as a function of applied potential for a cylindrical coupon of A430 SS immersed in $1.0 \mathrm{~N}$ sulfuric acid $\left(\mathrm{H}_{2} \mathrm{SO}_{4}\right)$. As shown in the current density versus applied potential graph in Figure 4-1, the PAR 273 instrument performed within specifications. All data fell within the high and low limits specified by the ASTM method, which has been developed from a round robin of potentiodynamic measurements performed by various laboratories.

Figure 4-1. The ASTM G5-94 Method Run by the PAR 273 Using Standard 1-Liter Test Cell.

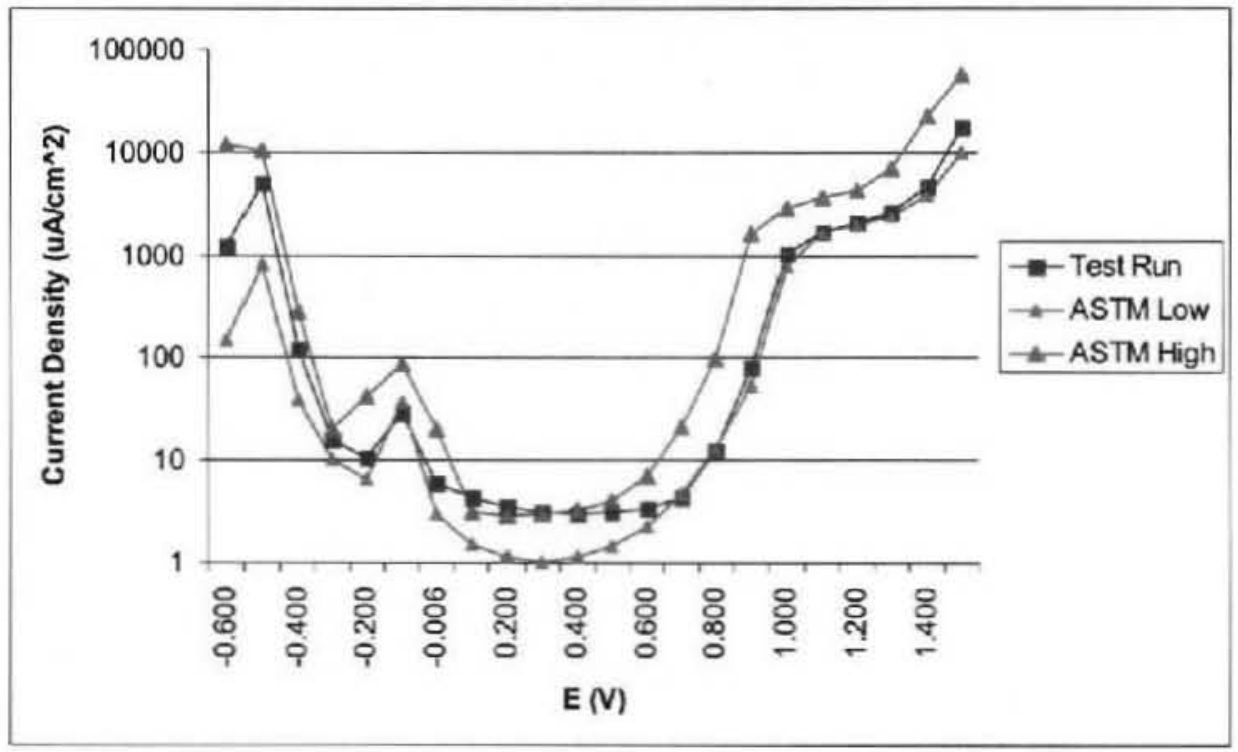




\subsubsection{Instrument Operation and Remote Electrochemical Cell Performance}

To confirm the efficacy of the sample jar/electrochemical cell design to be used in the hot cell corrosion potential testing, the ASTM G5-94 method was run in the 500-mL sample jar using an identical cell geometry (electrode placement) as would be used in the tank 241-AY-102 testing. Figure 4-2 shows that the $500 \mathrm{~mL}$-electrochemical test cell gave results consistent with the ASTM guidelines.

Figure 4-2. Response of 500-mL Electrochemical Cell to the ASTM G5-94 Method

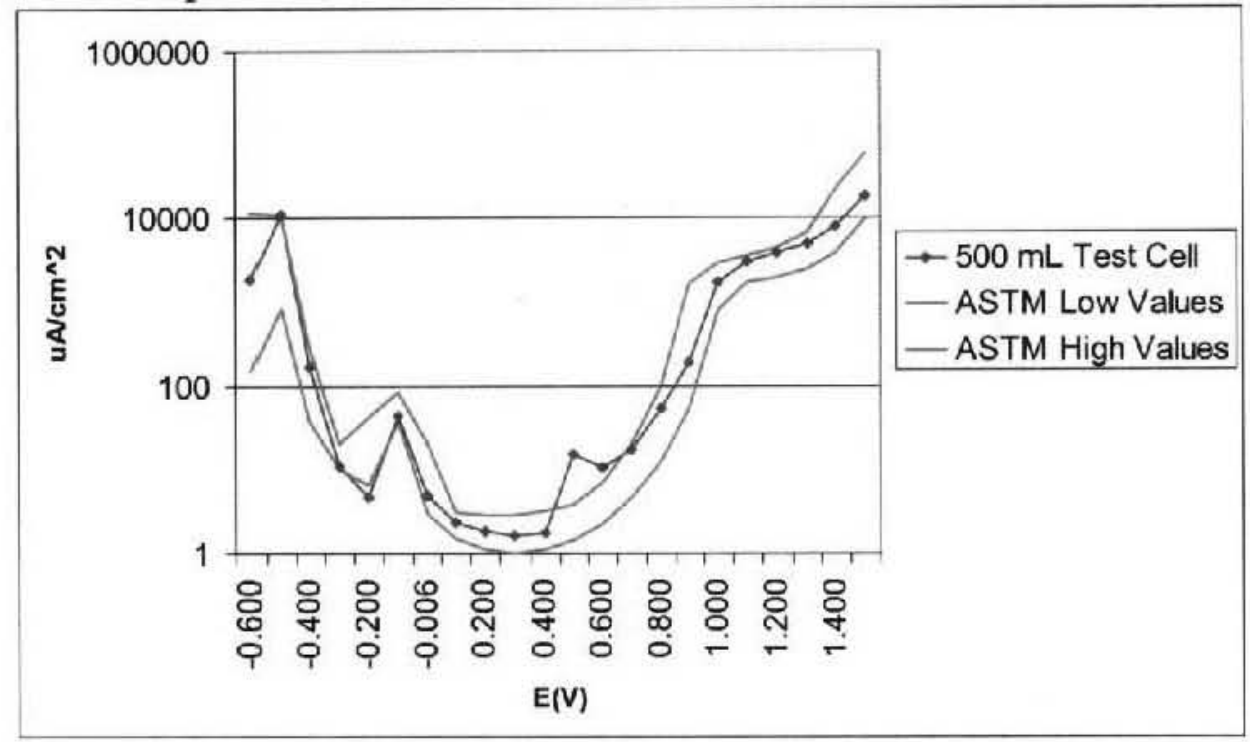

\subsubsection{Instrument Operation with Long Cable Leads}

The instrument cable leads to the 500-mL electrochemical cell for the tank 241-AY-102 sludge testing are longer than the typical leads because they must penetrate through the 11 A3 hot cell wall. Therefore, ASTM G5-94 method test runs were carried out with the longer instrument cable leads both in the 222-SA Laboratory environment as well as in the 222-S Laboratory $11 \mathrm{~A} 3$ hot cell to determine if the cable length adversely affected the data collected during potentiodynamic scans.

Figures 4-3 and 4-4 show the ASTM G5-94 method test response using long cable leads with the electrochemical cell located in the 222-SA Laboratory and 11 A3 hot cell, respectively. There is only a small effect of instrument cable length, mainly at high currents and applied potential. The variability of the ASTM type tests shown in the figures is acceptable because the general shape of the potentiodynamic curves track that of the standard test range very closely. The high and low curves of the ASTM standard method were derived from round robin laboratory data. Implicit in the range is acknowledgement that variation exists amongst the laboratories that performed the standard method tests used as a basis for establishing the range. The Figure 4-3 and 4-4 curves exemplify this variability as the tests were conducted using the same basic test configuration (only the location was different). Note that the Figure 4-4 curve for the actual arrangement in the 11 A3 hot cell is reasonably consistent with the ASTM G5-94 
standard range over the majority of the applied potentials tested. The apparent downward shift of current density at high potentials may arise from the extra impedance of the longer leads. However, the shift is not significant enough to warrant concern in this test program because most of the focus is in the passive region of the scans closer to the open-circuit potential and not at high potentials and current densities representative of the transpassive regions.

The ASTM G5-94 method was used as an instrument check during the course of the testing program with essentially the same results as presented in Figure 4-4.

Figure 4-3. Response of 500-mL Test Cell with Long Cable Leads in 222-SA Laboratory

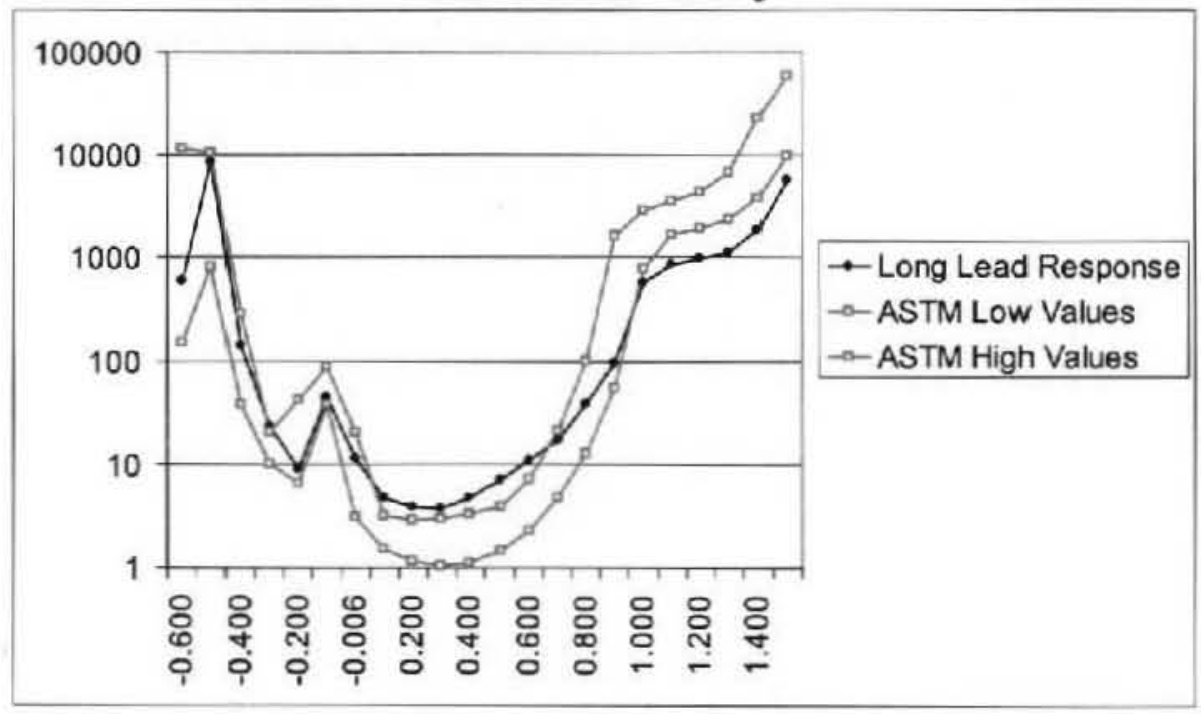

Figure 4-4. Response of 500-mL Test Cell with Long Cable Leads in 11 A3 Hot Cell

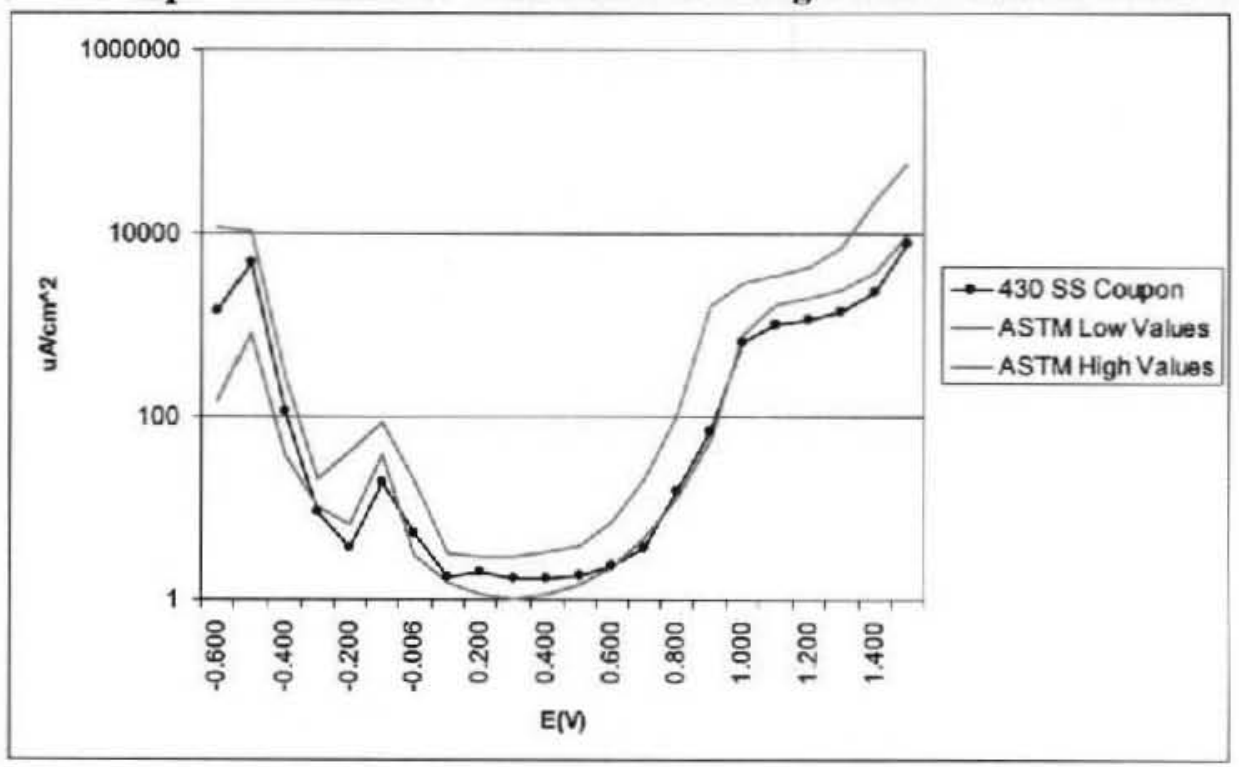




\subsection{TANK 241-AY-102 WASTE SIMULANT TESTING}

After demonstrating the efficacy of the electrochemical cell design and test instrumentation for making potentiodynamic measurements, electrochemical scans were carried out on tank 241-AY-102 supernatant and sludge simulants. The purpose of this testing was to confirm that the measurement procedures and equipment could be applied to more demanding test conditions, especially on sludge type materials. The supernatant and sludge simulant formulations are presented in Appendix D. The potentiodynamic scans were carried out at $0.166 \mathrm{mV} / \mathrm{sec}$ over the range of $-300 \mathrm{mV}$ versus open-circuit potential to $1,600 \mathrm{mV}$.

\subsubsection{Platinum to Platinum Scan Tests}

Potentiodynamic scans of the supernatant and sludge simulants were carried out configuring one platinum electrode as the working electrode and the other as the counter electrode. The reason for this test arrangement in the tank 241-AY-102 analyses was to distinguish between reactions occurring at the working electrode from chemical degradation of species within the tank 241-AY-102 simulants and corrosion reactions on the surface of the electrode. This same testing protocol was followed in testing the actual tank 241-AY-102 sludge material.

\subsubsection{Tank 241-AY-102 Supernatant Simulant Testing}

Figure 4-5 shows the potentiodynamic scan for the carbon steel working electrode immersed in the tank 241-AY-102 supernatant simulant as compared to the platinum electrode scan. The scan indicates that the carbon steel coupon remains in a passive region until approximately $800 \mathrm{mV}$. Above $800 \mathrm{mV}$, the current density rises sharply with increases in potential, which is representative of the transpassive zone. The gradual increase of the platinum scan in this region of the curve indicates that the response of the A515 coupon is caused by corrosion reactions at the coupon surface and not chemical reactions occurring in the waste. 
Figure 4-5. Current Densities for Tank 241-AY-102 Supernatant Simulant

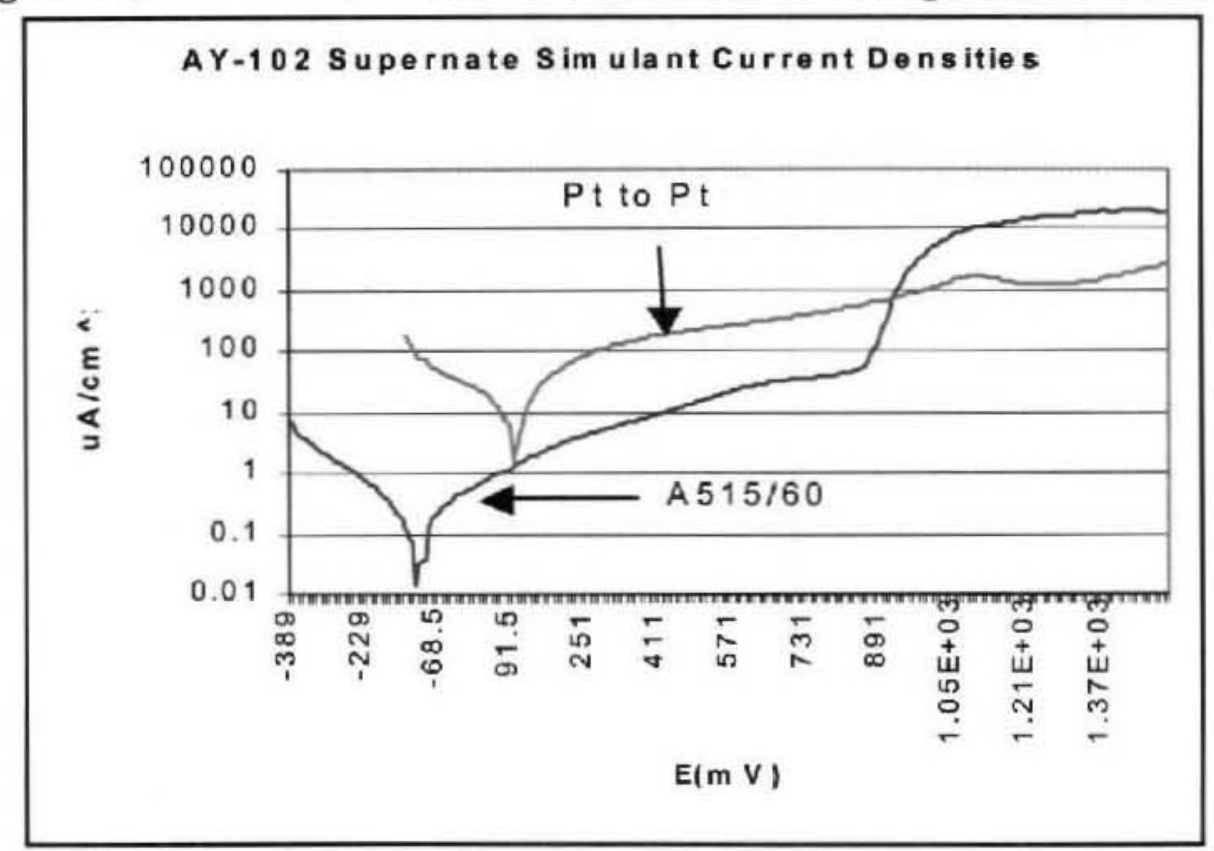

\subsubsection{Tank 241-AY-102 Sludge Simulant Testing}

Figure 4-6 shows the current densities from a potentiodynamic scan of the tank 241-AY-102 sludge simulant. From the graph, the passive region extends from the open-circuit potential to approximately $600 \mathrm{mV}$. Given that the shapes of the scans are typical of potentiodynamic measurements and that electrical continuity was maintained over the range of induced potentials, the testing demonstrated that corrosion potential testing of the tank 241-AY-102 sludge could be successfully accomplished.

Figure 4-6. Current Densities for Tank 241- AY-102 Sludge Simulant

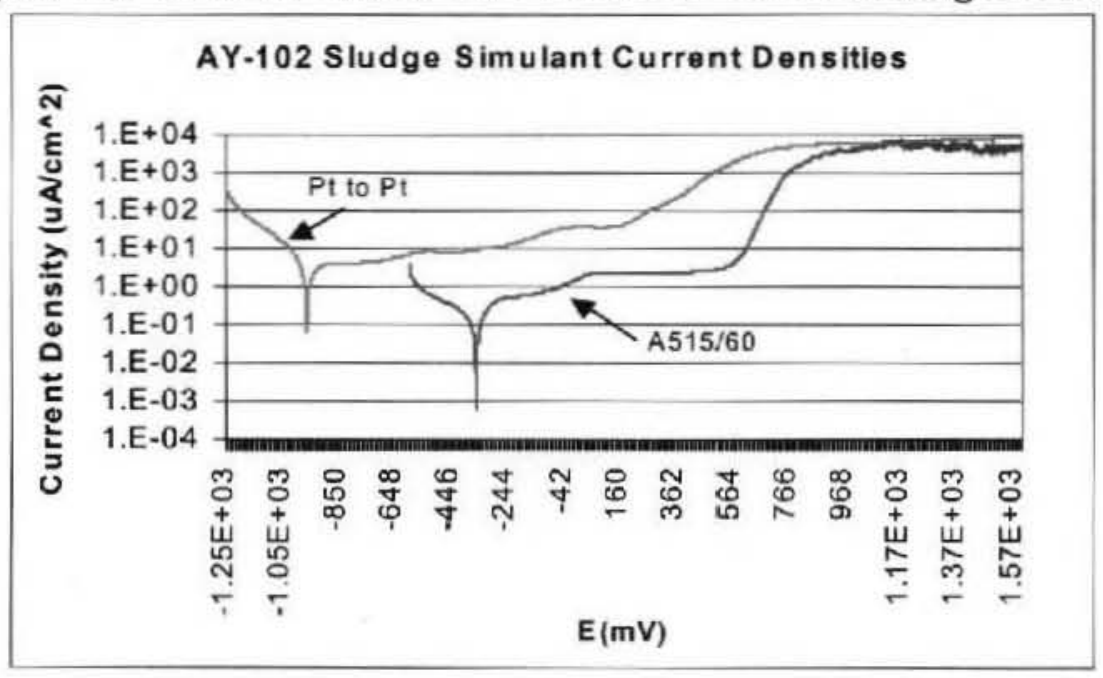




\subsection{ESTABLISHING OPEN CIRCUIT POTENTIAL}

Before any scan is carried out, the open circuit potential is measured. (The open circuit potential $\left(\mathrm{E}_{\mathrm{CORR}}\right)$ is the region where the oxidation and reduction current vectors sum to zero.) Each carbon steel specimen (coupon) was allowed to equilibrate with the waste (both the simulants and the actual tank 241-AY-102 sludge). If equilibrium ( $E_{C O R R}$ ) between the specimen and the surrounding sludge is not established, then a potential biasing of the Tafel plot may occur. This would then lead to inaccurate measurements of the corrosion current ( $\mathrm{i}_{\mathrm{CORR}}$ ) and calculated corrosion rate. Figures 4-7 and 4-8 are the result of an open circuit measurement equilibrated for 19 hours for the tank 241-AY-102 sludge simulant and the actual sludge material, respectively. The open-circuit potentials are the potentials represented by the asymptotes to the potential-time curves; approximately $-330 \mathrm{mV}$ for the sludge simulant and approximately $-347 \mathrm{mV}$ for the actual sludge.

\section{Figure 4-7. Open Circuit Potential in Tank 241-AY-102 Sludge Simulant}

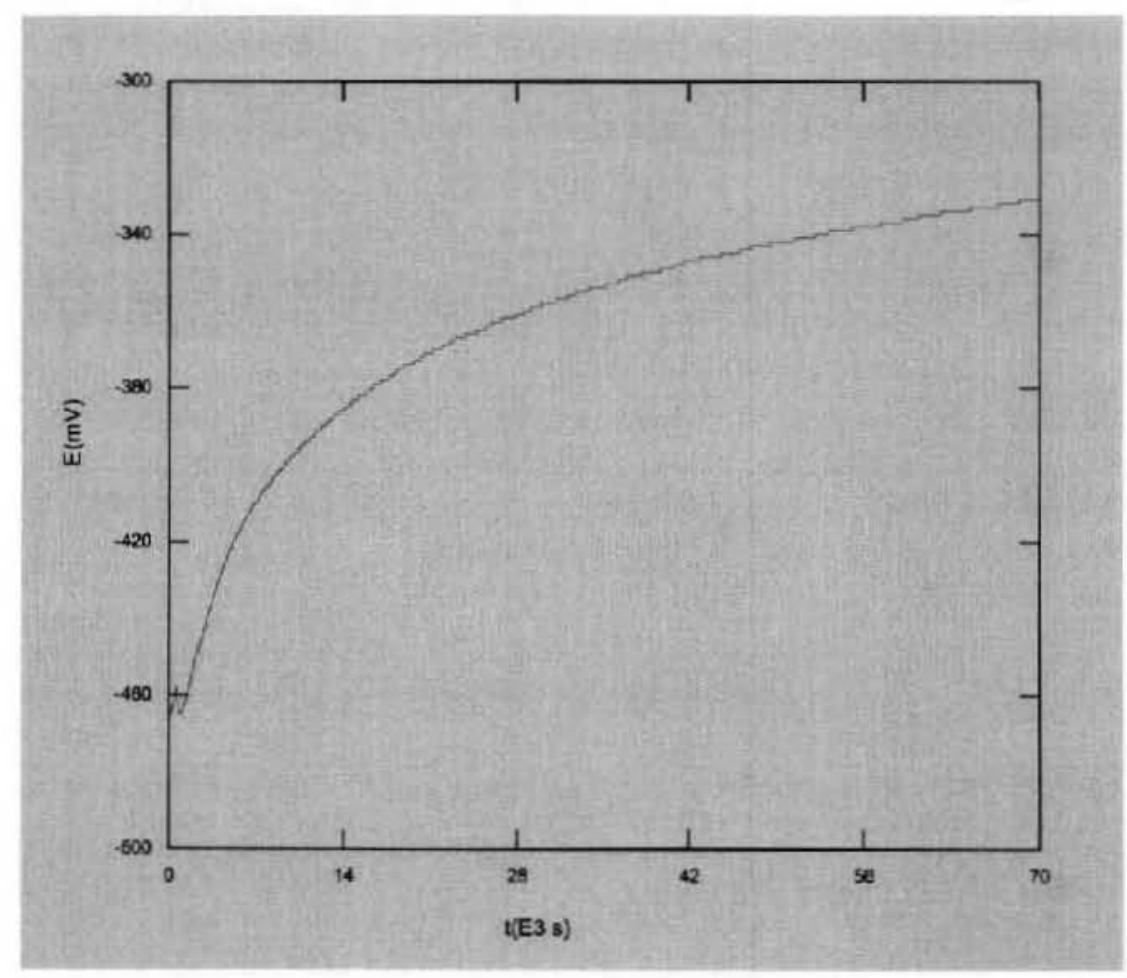


Figure 4-8. Open Circuit Potential in Tank 241-AY-102 Core Segment 13R1 Sludge

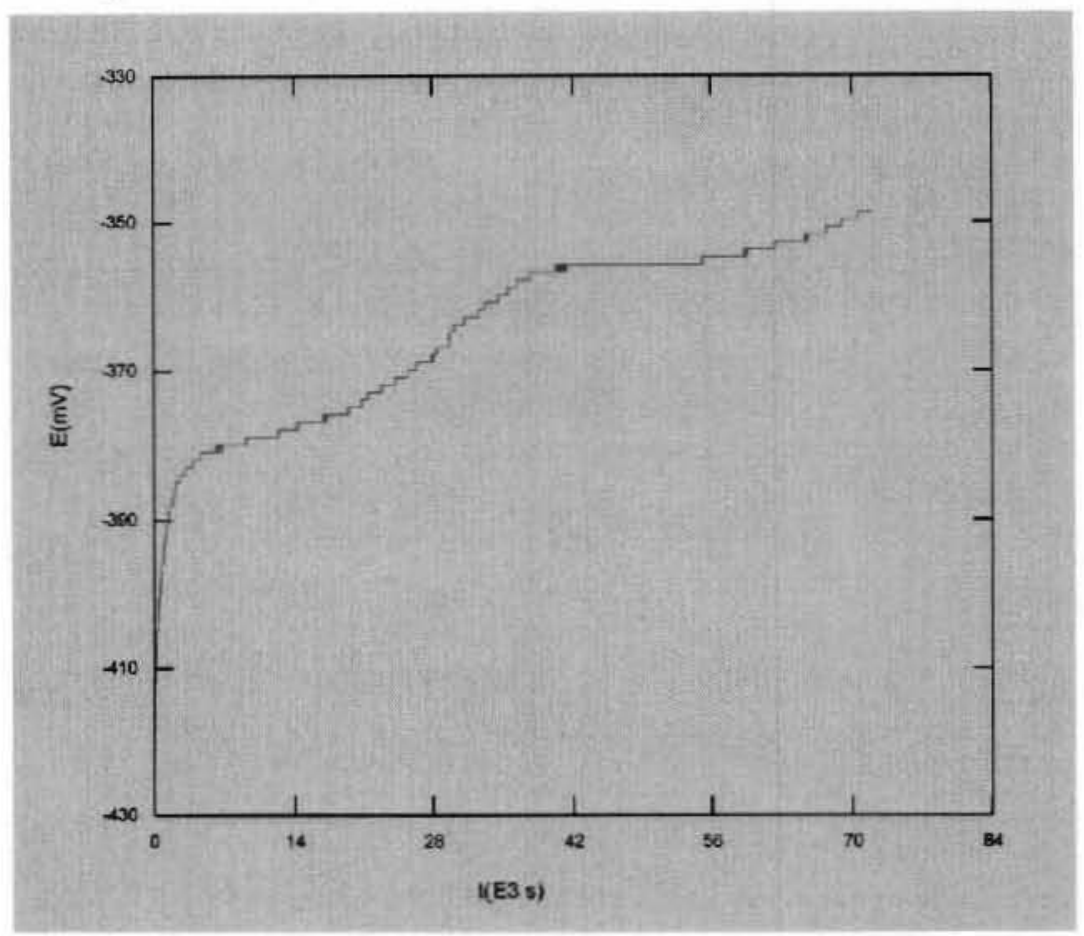

\subsection{TEMPERATURE CONTROL TESTING}

Corrosion potential tests of the tank 241-AY-102 sludge are to be carried out at ambient temperature $\left(\sim 24^{\circ} \mathrm{C}\right), 40^{\circ} \mathrm{C}$, and $60^{\circ} \mathrm{C}$ (the expected maximum seasonal tank temperature). To control the test temperature, the sample jar/electrochemical cell was equipped with a thermocouple placed in close proximity to the working electrode. A heating belt was placed around the electrochemical cell. To attain the required test temperature, an Iomega controller via a thermocouple feedback controlled the heating belt.

An experiment was carried out in the 222-SA Laboratory using the tank 241-AY-102 sludge simulant to determine the expected temperature profile of the sludge when the test coupon reaches the desired test temperature. This testing was done to demonstrate temperature control could be accomplished without experiencing large temperature gradients that could lead to drying of the sample. Thermocouples were introduced into the sludge simulant in a radial configuration through openings in the electrochemical cell cover.

Figure 4-9 shows the temperature profile from the sludge simulant heating test. Thermocouples were radially placed into the sludge simulant, equidistant from each other, with Thermocouple \#1 being in the center (where the working electrode would be located) and Thermocouple \#4 being at or near the outer edge of the sludge. From the 
graph, there is an approximate $8^{\circ} \mathrm{C}$ gradient from the outer sludge region of the cell to the centerline. Significant drying of the sludge simulant was not observed. Therefore, increasing temperature to the desired levels at the working electrode gave negligible impact to the rest of the sludge.

Figure 4-9. Electrochemical Cell Temperature Gradient for Heated Tank 241-AY-102 Sludge Simulant

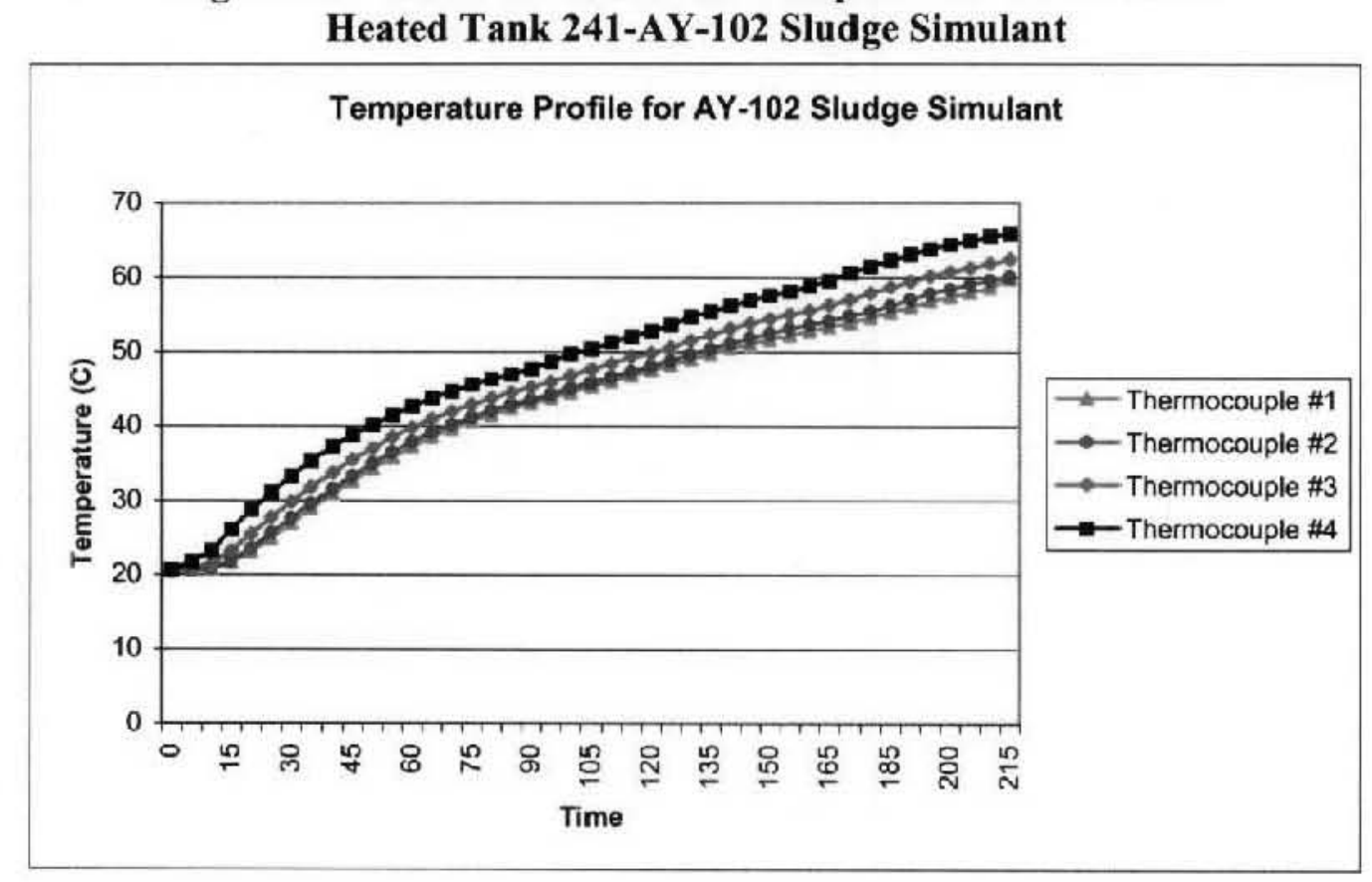


RPP 12077 Rev. 0

\subsection{TANK 241-AY-102 SLUDGE CORROSION POTENTIAL TEST RESULTS}

\subsection{SAMPLE EXTRUSION DESCRIPTION}

Segments 13R1, 13R, and 13BR were all extruded using the extrusion platform described in Section 3.1.2. After the preparation of each sampler (removal of quadralatch, cable cutting, etc.), it was then positioned vertically in the opening on the extrusion platform top plate with the collar pushed down on the top plate and over the electrochemical cell (Figure 5-1). The oxygen meter was positioned in close proximity to the sample jar inside the extrusion platform chamber. Argon gas was introduced into the enclosure through the sample collar and directionally drilled holes in the platform's top plate. After approximately 120 seconds of flow, the oxygen meter registered 0 percent, and the sampler was prepared for beginning the extrusion.

Once oxygen concentration inside the extrusion platform enclosure was depleted, the valve to the sampler was opened to begin the extrusion. The sampler valve was only partially opened to prevent the sampler's piston head from falling into the test cell after all of the sludge had been extruded from the sampler. Weights were added down the top of the sampler tube on to the top of the sampler piston to force the waste out of the lower end of the sampler and into the test cell. If the waste did not flow out of the sampler from just the force exerted by the weights, additional force was applied by hammering the weights to drive them further into the top end of the sampler.

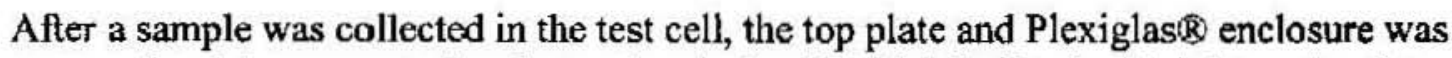
removed and the cover to the electrochemical cell, which is fitted with inlet and outlet argon gas ports, was fitted tightly onto the test cell. Argon gas was directed into the test cell opening during this transition. After the top of the test cell was in place, the argon supply tubing was connected to the inlet gas port and the sample purged with argon to remove any air from the cell that may have been entrained during the capping process. The cell was then removed from the extrusion platform, the argon gas control valves on the test cell cover closed, and the test cell moved to the $11 \mathrm{~A} 3$ hot cell where it was immediately reconnected to argon purge gas. The samples are maintained under argon during storage and analysis. 


\section{Figure 5-1. Extrusion of Tank 241-AY-102 Sludge Into Electrochemical Cell}

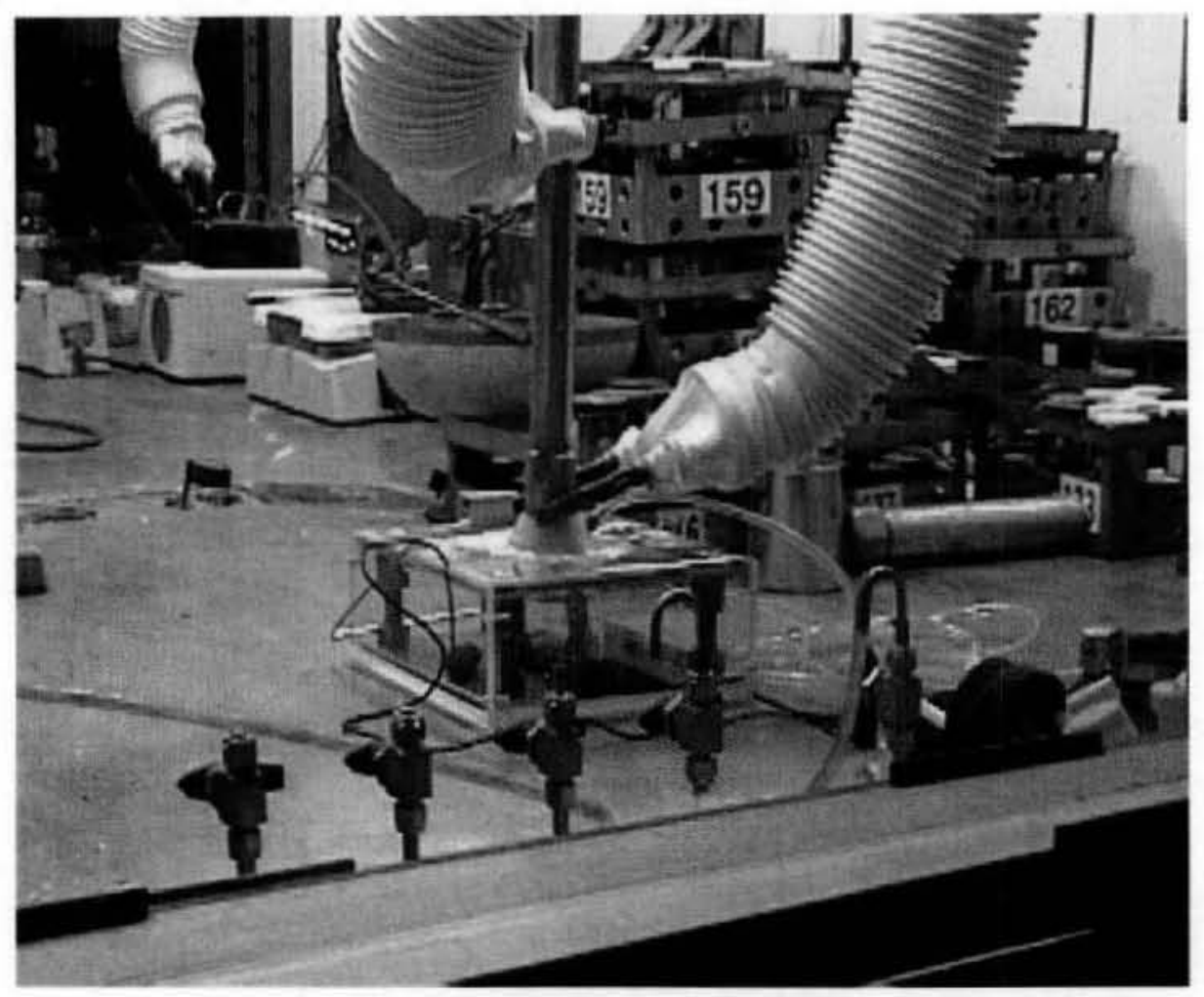

Segment 13R was extruded on May 1, 2002, and Segments 13R1 and 13BR were extruded on May 28, 2002. When a core sample is extruded in the laboratory, each core segment is classified according to the segment attributes given in Table 5-1. Segment 13R1 was classified as D3. Segment 13R (extruded first into the test cell) was also classified as D3 and 13BR (extruded into the same test cell to form a composite) was classified as D2. The description of the extrusions for tank 241-AY-102 core 300, segments 13R, 13R1, and 13BR are given in Appendix B.

Table 5-1. Segment Classification, Visual Observation

\begin{tabular}{|c|l|}
\hline Classification Code & \multicolumn{1}{c|}{ Appearance } \\
\hline D2 & $\begin{array}{l}\text { Sludge Slurry -- liquid comes off of segment, appears like } \\
\text { saturated to very wet mud }\end{array}$ \\
\hline D3 & $\begin{array}{l}\text { Wet Sludge - segment maintains cylindrical shape of sampler } \\
\text { when being extruded, appears wet, no liquid separation }\end{array}$ \\
\hline D4 & No Category \\
\hline D5 & $\begin{array}{l}\text { Dry Sludge - extrudes in discreet pieces, maintains cylindrical } \\
\text { shape from sampler }\end{array}$ \\
\hline
\end{tabular}




\subsection{CHEMICAL ANALYSIS OF CORE SEGMENTS}

Analytical analyses for segment 13 , which was obtained from the same location in tank 241-AY-102 as the segments used in the corrosion potential tests, are presented in Appendix C. Chemical analysis of the sludge interstitial liquid gave a pH of 12.1 or $0.018 \underline{\mathrm{M}}$ hydroxide, $0.05 \underline{\mathrm{M}}$ nitrite, and less than $0.003 \mathrm{M}$ nitrate. For this concentration of nitrate ion, the lower AC 5.15 concentration limits for the hydroxide and nitrite ions are greater than or equal to $0.01 \underline{\mathrm{M}}$ and $0.011 \underline{\mathrm{M}}$, respectively. Therefore, the sludge meets the corrosion control chemistry limits. Consequently, the corrosion potential measurements performed by this test program serve to confirm the in-specification condition of the sludge in contrast to the original objective to test the corrosion behavior of A515 carbon steel in out-of-specification sludge material.

Lithium bromide ( $\mathrm{LiBr}$ ) was used as the hydrostatic head fluid during the tank core sampling operations. The concentration of $\mathrm{LiBr}$ used in the sampling was $0.3 \pm 0.01 \mathrm{M}$ $(26.04 \mathrm{~g} / \mathrm{L})$. The analysis for segment $13 \mathrm{R} 1$ yielded an average concentration of bromide at $509 \mathrm{\mu g} / \mathrm{g}$. Lithium was reported as under the method detection limit.

For the composite segments $13 \mathrm{BR}$ and $13 \mathrm{R}$, the analysis yielded bromide as below the method detection limit and lithium as $4.93 \mu \mathrm{g} / \mathrm{g}$. For the segments $13 \mathrm{BR}$ and 13R composite, the weight percent water by thermogravimetric analysis (TGA) was determined to be 48.7 percent (average).

The concentration of $\mathrm{LiBr}$ (using reported values and amount extruded for each segment) is approximately 1 millimole $(\mathrm{mM})$ for $13 \mathrm{R} 1$ and less than $1 \mathrm{mM}$ for the composite 13BR and 13R. Given these very low concentrations, it is unlikely that $\mathrm{LiBr}$ solution used in the core sampling had a significant effect on the corrosion potential measurement results.

\subsection{TANK 241-AY-102 SEGMENT 13R1 CORROSION POTENTIAL TESTING}

\subsubsection{Segment 13R1 Extrusion}

Approximately $200 \mathrm{~mL}$ of sludge was collected in the electrochemical cell, and was judged to be category D3 type waste (see Table 5-1 for category descriptions). The cover was placed on the test cell while maintaining argon gas flow into the cell opening. After the cover was secured, argon flow was re-established through the inlet argon port and the cell headspace purged with argon for several minutes. The stopcocks of the inlet and outlet argon ports were then turned to the off position and the sample transported to the 11 A 3 hot cell. Once there, argon gas flow was re-established to the headspace of the test cell. The 13Rl sludge collected would next be subjected to the electrochemical scans. 


\subsubsection{Open Circuit Potential}

Figure 4-8 gives the open circuit potential ( $\mathrm{E}_{\mathrm{CORR}}$ ) during the equilibration time for segment 13R1 sludge. The open circuit potential is estimated at $-347 \mathrm{mV}$. The values recorded for open circuit potential may vary from test coupon to test coupon. The reason for this variance among the coupons may be ascribed to such factors as differences in coupon surface characteristics, compositional differences between different lots of the steel used in fabricating the coupons, temperature variations, and non-homogeneity of the waste undergoing testing.

\subsubsection{Electrochemical Scans}

Core segment $13 \mathrm{R} 1$ sludge was to be examined at hot cell ambient temperature $\left(\sim 24^{\circ} \mathrm{C}\right)$. At ambient temperature, the linear polarization, Tafel, and potentiodynamic scans were performed successfully. The scans are presented in Appendix E. Figure 5-2 shows the potentiodynamic scan relating current density to the applied potential. Note that the passive region exists from the open circuit potential to approximately $600 \mathrm{mV}$. The scan above $600 \mathrm{mV}$ may reflect the beginning of the transpassive zone. The platinum current density scan is presented as a comparison. The response of both the A515 Grade 60 coupon and the platinum electrode are essentially the same above $600 \mathrm{mV}$. This likely indicates that the A515 Grade 60 response in the high potential range is being caused by electrochemical redox effects within the sludge.

Figure 5-2. Tank 241-AY-102 Core Segment 13R1 Sludge

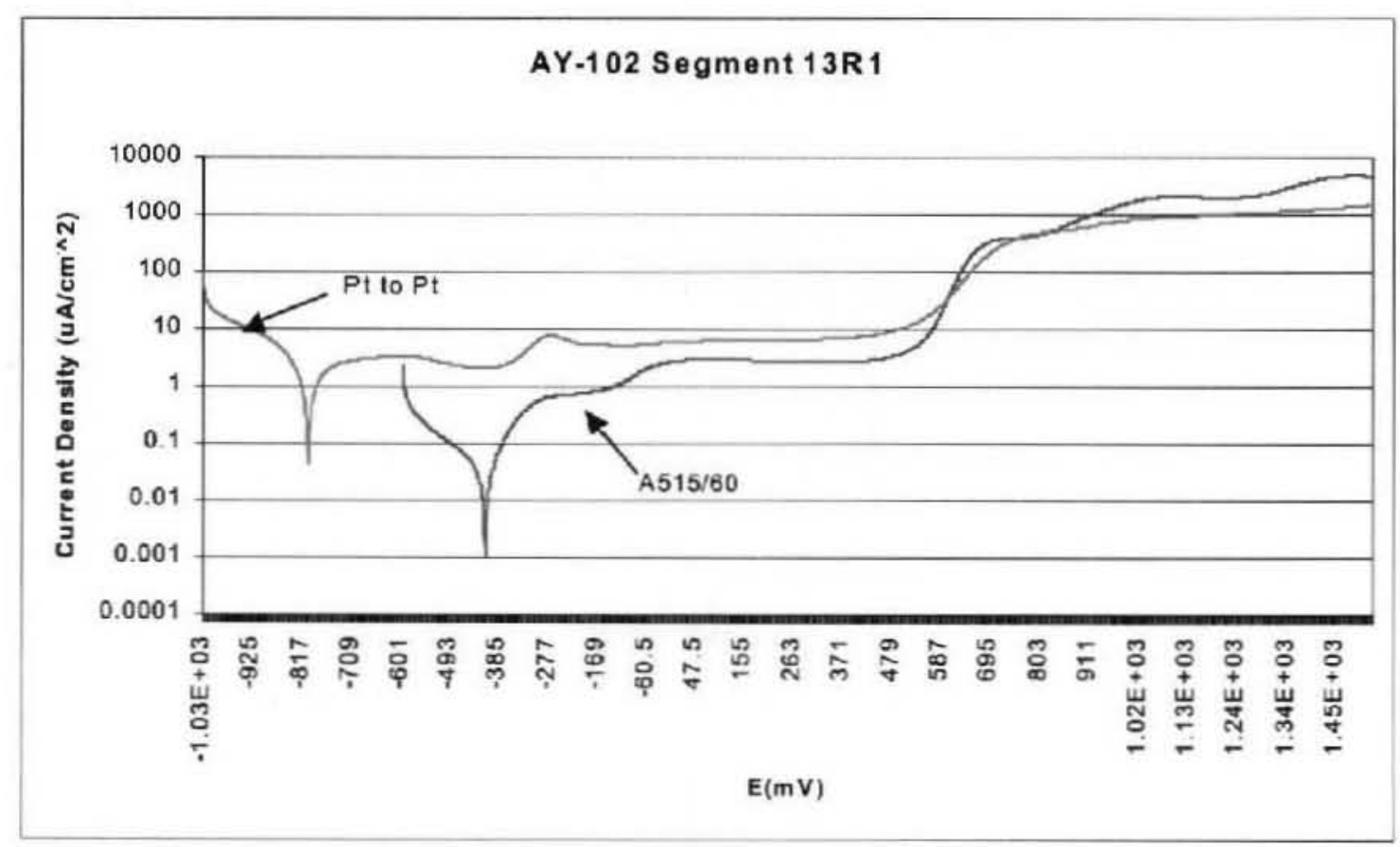

Potentiodynamic Scan at $24^{\circ} \mathrm{C}$ 


\subsubsection{Lessons Learned}

The plan also included making electrochemical scans at $40^{\circ} \mathrm{C}$ and $60^{\circ} \mathrm{C}$. After scanning at $24^{\circ} \mathrm{C}$, segment $13 \mathrm{R} 1$ was heated to $40^{\circ} \mathrm{C}$ to prepare for the next set of scans. However, the sludge sample dried out and shrank away from the centrally located working electrode upon heating to $40^{\circ} \mathrm{C}$. This broke the electrical connection and rendered the sample useless for further electrochemical scans. Figure 5-3 shows the sludge after heating to $40^{\circ} \mathrm{C}$ with the exposed working electrode at the center of the test cell.

The constant exposure to dry argon flowing over the sludge sample also contributed to drying the sample.

A minimum of $250 \mathrm{~mL}$ is needed to perform electrochemical scans at elevated temperatures. With $200 \mathrm{~mL}$ test material for segment $13 \mathrm{R} 1$ electrochemical scans, the working electrode is barely submerged in the sludge. Only a minor amount of drying will cause the sludge to shrink from around the test coupon, resulting in breaking electrical continuity. Using a higher volume of sludge in the test cell will help to mitigate this problem.

Figure 5-3. Tank 241-AY-102 Core Segment 13R1 Sludge after Heating to $40^{\circ} \mathrm{C}$
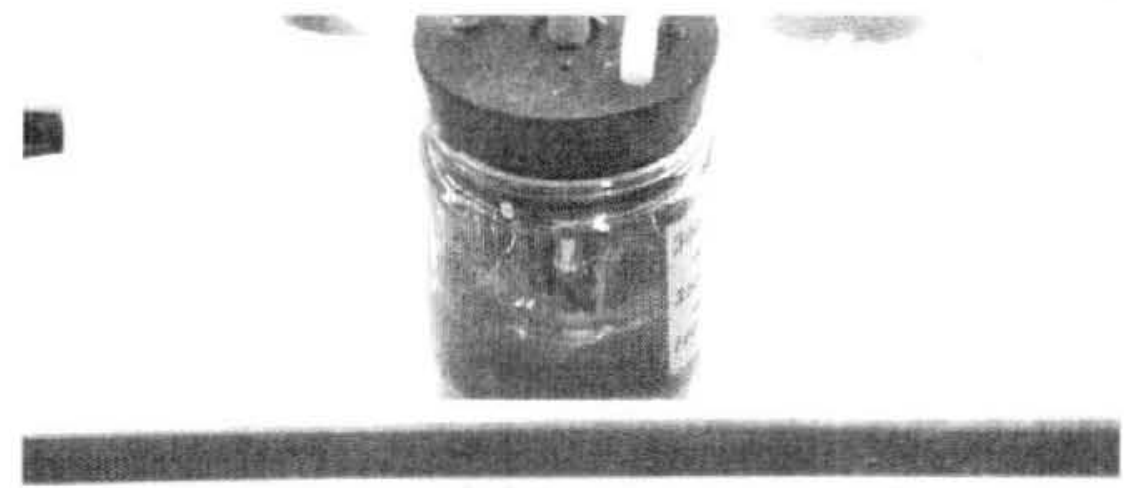

Note shrunken area around coupon. 
RPP 12077 Rev. 0

\subsection{TANK 241-AY-102 SEGMENTS 13R AND 13BR COMPOSITE CORROSION CONTROL TESTING}

\subsubsection{Application of Lessons Learned}

Sample 13R 1 was under a dry argon gas purge, albeit for a short period of time. Because of the rapid drying observed under the conditions of dry argon gas purge and elevated temperature $\left(40^{\circ} \mathrm{C}\right)$, a decision was made to sparge the argon gas through deionized water for subsequent corrosion potential test runs in order to minimize drying of the sludge sample. Therefore, the configuration for the tank 241-AY-102 core segment $13 R$ and 13BR sludge composite test runs was as follows. The argon gas was introduced into a flask containing deionized water through a fine sintered ceramic tip submerged in the water. This formed micron-sized bubbles that were humidified as the bubbles rise through the column of water and break from the surface into the headspace of the flask. The humidified gas then exited the flask and was introduced into the electrochemical cell headspace through a polypropylene tube fitted with a polypropylene stopcock for controlling the gas flow. The argon gas exited the test cell diametrically opposite from the gas inlet through a similar tube and stopcock into a second flask with water. The tip of the polypropylene exit tube was immersed in the water. This allowed for observating the bubbling action and, therefore, gave an indication that argon gas was flowing over the sludge sample in the test cell.

The water vapor added to the dry argon gas sparged through the deionized water was not expected to have an effect on the characteristics of the sludge sample. This would be confirmed if no accumulation of water was observed on the surface of the sample throughout the testing. Condensation would occur in the test cell only if the humidified argon reached its dew point, which would require a drop in temperature for the system from ambient conditions. The deionized water and the test apparatus, including its water flask, tubing and valves would be kept at ambient conditions throughout the testing from the fairly constant hot cell ventilation air temperature. Initially, the test condition with the sample material also at ambient temperature would not be expected to cause water to condense in the test cell because of the constant temperature of the system. At the higher test temperatures of $40^{\circ} \mathrm{C}$ and $60^{\circ} \mathrm{C}$, water definitely would not condense in the cell because the higher temperatures would tend to lower the saturation level of the water vapor in the headspace gas flow.

\subsubsection{Segments 13R and 13BR Extrusions}

For segment $13 R$, approximately $250 \mathrm{~mL}$ of wet sludge categorized as D2 (see Table 5-1) was collected under inert conditions. Segment $13 B R$ yielded approximately $200 \mathrm{~mL}$ of D3 type sludge, also extruded under an argon purge. Both segments were collected in the same sample jar/electrochemical cell. The cover was placed on the test cell during argon gas flow to its opening. After the cover was secured, argon flow was re-established through the inlet argon port and the cell headspace purged with argon for several minutes. The stopcocks of the inlet and outlet argon ports were then turned to the off position and 
the sample transported to the $11 \mathrm{~A} 3$ hot cell. Once there, argon gas flow (sparged through deionized water) was re-established to the headspace of the test cell.

\subsubsection{Open Circuit Potential}

Corrosion potential measurements on A515 Grade 60 carbon steel test coupons immersed in the 13R and $138 \mathrm{R}$ composite were performed at ambient hot cell temperature $\left(\sim 24^{\circ} \mathrm{C}\right), 40^{\circ} \mathrm{C}$, and $60^{\circ} \mathrm{C}$. Each coupon of carbon steel was allowed 12 hours to equilibrate to open circuit potential at its test temperature before a scan was performed. This time period was based on the test scan observations carried out using both the tank 24l-AY-102 sludge simulant and the segment 13R1 sludge.

\subsubsection{Electrochemical Scans}

After the first coupon of A515 Grade 60 carbon steel was introduced to the segment 13R and 13BR composite and allowed to equilibrate for 12 hours at ambient temperature, a potentiodynamic scan was attempted. The first set of electrochemical scans was attempted with the PAR 273 potentiostat/galvanostat. The PAR 273 exhibited electronic problems and failed to generate normal potentiodynamic scan curves. Therefore, the PARSTAT 2263 potentiostat/galvanostat was installed in place of the PAR 273 after first verifying its operation by performing the ASTM G5-94 method. Upon connecting to the electrochemical cell containing segment $13 R$ and 13BR composite and beginning the electrochemical scan process, the signal to noise ratio for the PAR 2263 was inadequate resulting in generation of unusable data. A search for the cause of the problem resulted in taking the following actions:

- The reference electrode Luggin was initially suspected. Observation of the Luggin tip through the hot cell window appeared to indicate that it could be plugged. The Luggin was replaced, but this did not correct the problem.

- The next component of concern was the reference electrode itself. It was replaced with another standard calomel electrode (Radiometer Model Number B20B110). Again, this did not correct the problem.

- An ASTM G5-94 method scan was then run which resulted in noise. This convinced the vendor that the problem was with the instrument.

The instrument was returned to the vendor. The cause of the problem was an internal ground wire that made sporadic contact with the ground terminal. Once repaired, the instrument operated properly.

Because of the observed plugged condition of the Luggin tip, the decision was made to keep the Luggin bridge out of the sludge and soaking in $1 \mathrm{~N}$ sulfuric acid (washed liberally with distilled water before reuse) except when performing a scan. This minimized potential plugging of the ceramic tip during the different stages of the test, i.e., open circuit equilibration, sample heating, and electrochemistry testing. 
Because of the time required to run all three scans (linear polarization, Tafel, and potentiodynamic) and out of concern for potential drying of the sample at elevated temperatures, only a potentiodynamic scan of the Segment $13 \mathrm{R}$ and $13 \mathrm{BR}$ composite was carried out at all three temperatures. Coupon (A515 Grade 60 carbon steel) replacement occurred at each test temperature and it was allowed to equilibrate for 12 hours before beginning its scan.

Appendix F presents the suite of potentiodynamic scans obtained from the segment $13 \mathrm{R}$ and 13BR composite. Figure 5-4 compares the current densities of the three-temperature scans and platinum scans carried out at $24^{\circ} \mathrm{C}$ and $60^{\circ} \mathrm{C}$. The potentiodynamic scans for the carbon steel coupons indicate that the open circuit potential is within the passive region. This is supported by the relatively narrow response of the current density versus the applied potential from open-circuit potential up to approximately $650 \mathrm{mV}$. The slope of the scans rise exponentially over a few hundred $\mathrm{mV}$, beginning at approximately $650 \mathrm{mV}$ to approximately $900 \mathrm{mV}$, reflective of a potential transpassive zone. However, similar to the scan for segment 13R1 (see Section 5.3.3), the similarity between the platinum scans and steel coupon scans within this voltage range may be indicative of reactions induced within the waste as opposed to corrosion reactions at the steel coupon surfaces.

The response of the scans as a function of temperature does indicate a slight effect. However, the responses at the $40^{\circ} \mathrm{C}$ and $60^{\circ} \mathrm{C}$ scans are somewhat identical.

Figure 5-4. Tank 241-AY-102 Core Segment 13R1 and 13BR Composite Potentiodynamic Scans at $24^{\circ} \mathrm{C}, 40^{\circ} \mathrm{C}$, and $60^{\circ} \mathrm{C}$

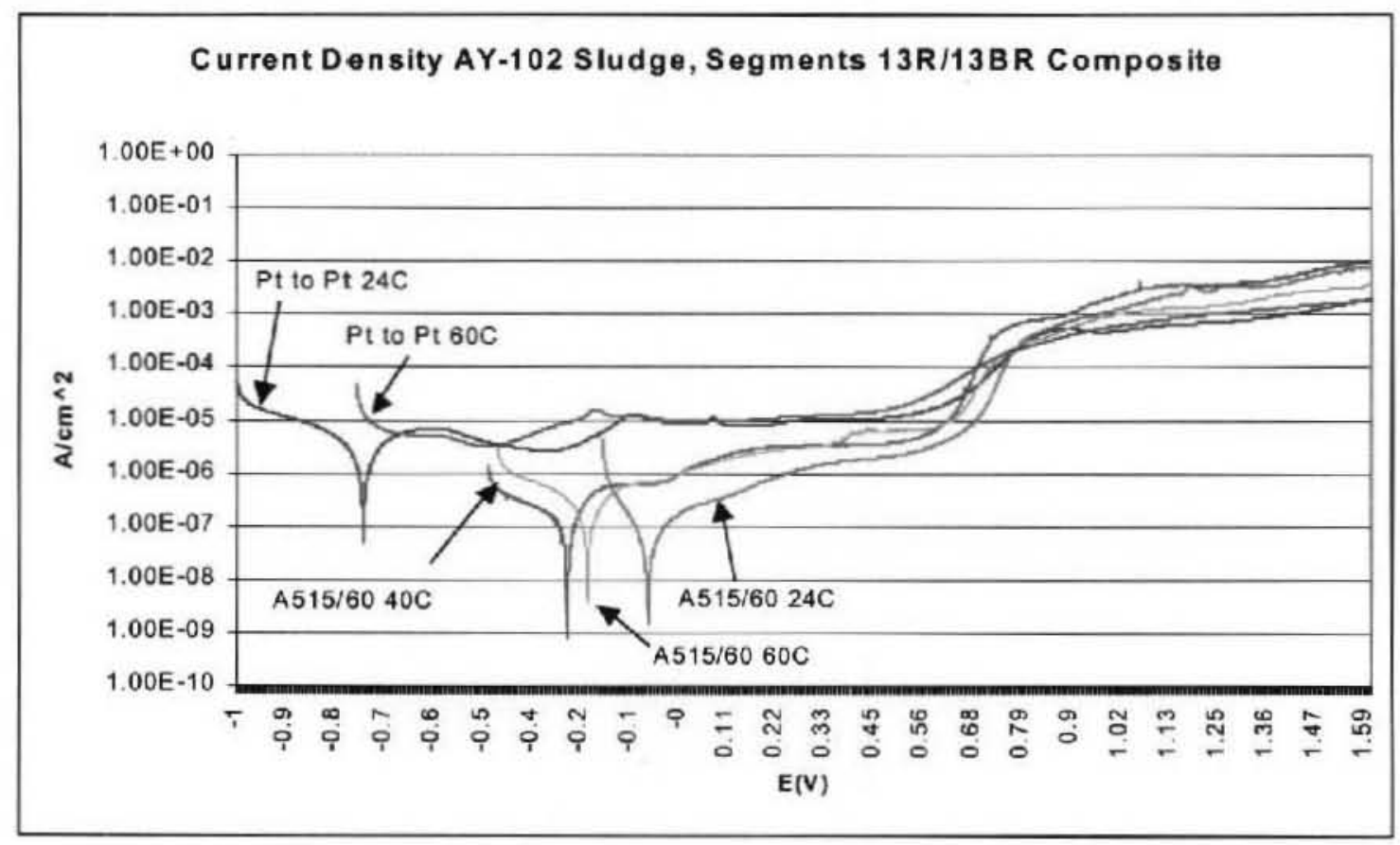


RPP 12077 Rev. 0

\subsection{DISCUSSION OF TANK 241-AY-102 SLUDGE CORROSION POTENTIAL TEST RESULTS}

Table 6-1 is a synopsis of the electrochemical corrosion scans.

Table 6-1. Corrosion Rates Calculated from the Scans of Tank 241-AY-102 Sludge

\begin{tabular}{|c|c|c|c|c|c|c|c|}
\hline Segment & $\begin{array}{c}\text { Temperature } \\
\left({ }^{\circ} \mathrm{C}\right)\end{array}$ & $\begin{array}{l}\mathbf{E}_{\text {corr }} \\
(\mathrm{mV})\end{array}$ & $\begin{array}{l}i_{\text {corr }} \\
(\mu \mathrm{A})\end{array}$ & $\begin{array}{c}\beta_{c} \\
\text { (mV/decade) }\end{array}$ & $\underset{\text { (mV/decade) }}{\beta_{\hat{A}}}$ & $\begin{array}{c}\text { Corr. Rate } \\
\text { (mpy) }\end{array}$ & $\begin{array}{l}\chi^{2(2)} \\
\text { (Tafel } \\
\text { Slopes) }\end{array}$ \\
\hline 13R1 & 24 & -347 & 0.21 & 174 & 55 & $1.71 \mathrm{E}-2$ & 0.89 \\
\hline $13 \mathrm{BR} / 13 \mathrm{R}$ & 24 & -79 & 0.43 & 105 & 248 & $3.5 \mathrm{E}-2$ & 5.51 \\
\hline 13BR/13R & 40 & -262 & 1.33 & 855 & 133 & $1.07 \mathrm{E}-1$ & 1.68 \\
\hline 13BR/13R & 60 & -218 & 2.94 & 739 & 184 & $2.39 \mathrm{E}-1$ & 1.16 \\
\hline
\end{tabular}

Note: ${ }^{a} \chi^{2}=\Sigma\left(i_{\text {observed }}-i_{\text {expected }}\right)^{2} / i_{\text {expocited }}$

The above corrosion rates were confirmed by hand calculations using equations presented in Section 2.2. Table 6-2 shows the results of those calculations along with the PAR 273 potentiostat software derived corrosion rates for segment 13R and PARSTAT 2263 software derived corrosion rates for the $13 \mathrm{BR} / 13 \mathrm{R}$ composite. The corrosion rate values compare favorably between the methods. The differences can be attributed to how the Tafel slopes are determined. The software automatically picks the tangent lines to the cathodic and anodic curves of the Tafel Plot, whereas the hand calculations use slopes manually estimated from the graph (See Figure 2-2).

Table 6-2. Comparison of Corrosion Rates Derived by Hand Calculations to Corrosion Rates Derived by Software

\begin{tabular}{|l|c|c|c|c|}
\hline $\begin{array}{c}\text { Segment } \\
\text { (Temperature) }\end{array}$ & $13 \mathrm{R} 1\left(24^{\circ} \mathrm{C}\right)$ & $13 \mathrm{BR} / 13 \mathrm{R}\left(24^{\circ} \mathrm{C}\right)$ & $13 \mathrm{BR} / 13 \mathrm{R}\left(\mathbf{4 0} 0^{\circ} \mathrm{C}\right)$ & $13 \mathrm{BR} / 13 \mathrm{R}\left(60^{\circ} \mathrm{C}\right)$ \\
\hline $\begin{array}{l}\text { Corrosion Rate } \\
\text { Software Derived }\end{array}$ & $1.71 \mathrm{E}-2$ & $3.5 \mathrm{E}-2$ & $1.07 \mathrm{E}-1$ & $2.39 \mathrm{E}-1$ \\
\hline $\begin{array}{l}\text { Corrosion Rate } \\
\text { Hand Calculation } \\
\text { Derived }\end{array}$ & $2.60 \mathrm{E}-2$ & $2.60 \mathrm{E}-2$ & $1.20 \mathrm{E}-1$ & $4.60 \mathrm{E}-1$ \\
\hline $\begin{array}{l}\text { Ratio hand } \\
\text { calculations: } \\
\text { software } \\
\text { calculations }\end{array}$ & 1.52 & 0.74 & 1.12 & 1.92 \\
\hline
\end{tabular}

The complete potentiodynamic scans obtained in this work are contained in Appendices $\mathrm{E}$ and F. A comparison of results for the core segment 13BR and $13 \mathrm{R}$ composite is presented in Figure 5-4. The curves indicate a passive region between approximately $0 \mathrm{~V}$ and $0.6 \mathrm{~V}$ (standard calomel electrode (SCE)) with current densities on the order of $10^{-6} \mathrm{microamps} / \mathrm{cm}^{2}$. At about $0.6 \mathrm{~V}$ (SCE), there appears to be a 
film-breakdown phenomenon for all temperatures where the current rises by two or more orders of magnitude. Eventually, the current reaches a higher current density plateau; possibly due to mass transfer limitation.

As shown in Table 6-1, the effects of increasing temperature on the polarization behavior of the carbon steel in the segment 13R and 13BR composite includes an increase in corrosion current ( $\mathrm{i}_{\mathrm{COkK}}$ ) and corrosion rate. Interestingly, the rate for corrosion in the 13R and 13BR composite approximately doubles for each 10-degree temperature increment, a result surprisingly consistent with most chemical reactions. In all cases, however, the corrosion rates were very low, on the order of $10^{-2}$ to $10^{-1}$ mpy (mils per year). Although no corrosion allowance is specified in the tank 241-AY Tank Farm primary tank design specifications, a 0.05 -inch corrosion allowance over the design life of a DST is normally assumed (B-120-D1, 1976). For most tank farm DSTs, which have a design life of 50 years, this corrosion allowance translates into a design basis corrosion rate of 1 mpy. These measured corrosion rate results indicate that minimal corrosion occurs for the carbon steel in the sludge medium over the entire temperature range of interest.

Consistent with the small increase in corrosion rate with temperature, there is also a slight loss of passivity with increasing temperature, particularly between $24^{\circ} \mathrm{C}$ and $40^{\circ} \mathrm{C}$. As shown in Figure 5-4, the passive current plateau between approximately $0 \mathrm{~V}$ and $0.6 \mathrm{~V}$ (versus SCE) occurs at lower current density for $24^{\circ} \mathrm{C}$ than for $40^{\circ} \mathrm{C}$ and $60^{\circ} \mathrm{C}$. The increase in corrosion rate may be related to this decrease in passivity, possibly in turn, arising from an expected increase in solubility of the passive oxide with increasing temperature.

As shown in Table 6-1 and Figure 5-4 there is also a slight shift of the open-circuit potential to more negative values upon increasing temperature from $24{ }^{\circ} \mathrm{C}$ to $40{ }^{\circ} \mathrm{C}$. The open-circuit potential for the $60^{\circ} \mathrm{C}$ test appears close to that of the $40^{\circ} \mathrm{C}$ test, but it may also increase slightly. The negative shif between $24^{\circ} \mathrm{C}$ and $40^{\circ} \mathrm{C}$ may be due to several factors; one may be the decreased solubility of oxygen upon increasing temperature. Some dissolved oxygen may still be present in the waste sample and, therefore, be reduced upon heating.

There are no apparent reactions involving solution-species-only that interfere with interpretation over much of the potential range examined. The curves for platinum do not show any significant peaks in the potential regions overlapped by the steel curves, i.e., above about $-0.1 \mathrm{~V}$. Similarly, there are no significant peaks for the steel curves in this region either. Between about $-0.1 \mathrm{~V}$ and $0.65 \mathrm{~V}$, passive corrosion currents for the steel are being exhibited.

The "breakdown" potential for the segment 13R1 sample and the 13BR/BR composite sample are very close for all steel curves (and the platinum also); approximately $0.6 \mathrm{~V}$. A "breakdown" potential is the location on the potentiodynarnic scan where chemical reactions within the sample material (as opposed to corrosion reactions at the coupon surface) cause a simultaneous sharp increase in current density for both the working 
electrode and platinum electrode. At about $0.6 \mathrm{~V}$, the electrolyte in the samples is decomposing. To ascertain if this is the case, performing cyclic polarization curves may yield more information about the surface behavior of the carbon steel test coupon. The capability to perform cyclic polarization test was not available when this test program was begun.

\subsection{CONCLUSIONS}

1. The experimental corrosion potential protocol was successful.

2. The test cell design was suitable for carrying out electrochemical studies, as evidenced by comparison of ASTM G5-94 "like" tests.

3. The anaerobic extrusion of tank $241-\mathrm{AY}-102$ sludge was performed successfully in a hot cell environment.

4. Linear polarization scans yielded good polarization curves from tank 241-AY-102 sludge samples using the procedures employed in the test.

5. The scans exhibited reasonable features, including evidence for passivation.

6. The sludge samples must be kept under a humidified argon purge to control sample dry out during testing. If the sludge sample contains a high proportion of solids, heating without first humidifying the argon purge gas will result in loss of electrical conductivity that interferes with establishing electroconductivity.

7. Corrosion rates of A515 Grade 60 carbon steel contacting tank 241-AY-102 sludge are low over the temperature range $24^{\circ} \mathrm{C}$ to $60^{\circ} \mathrm{C}$, that is, approximately $10^{-2}$ to $10^{-1}$ mpy. This corrosion rate is over an order of magnitude less than the design basis corrosion rate of 1 mpy for most DSTs.

8. The corrosion potential tests of the A515 Grade 60 carbon steel coupon would indicate that the tank 241-AY-102 steel in contact with sludge is in the passive region of the potentiodynamic curve.

9. The electrochemical measurements validate the low end of the AC 5.15 chemistry control limits because the sludge composition in the bottom of the tank at the location of the core samples used in the corrosion potential tests was discovered to be just inside the specification boundary. 


\subsection{RECOMMENDATIONS}

1. Comparison of corrosion behavior as a function of sludge composition should be performed. In particular, it is desirable to know the corrosion rate as a function of sludge wetness (dilution with supernatant). Both corrosion reactions and the efficacy of the measurement methods themselves are highly dependent on electrolyte conductivity, which, in turn, is strongly influenced by how much water the sludge contains. Solution agitation during electrochemical measurements may also help to identify conditions where mass transport of solution species is rate limiting.

2. Because the carbon steel specimens passivate in the sludge medium, cyclic polarization curves should be obtained to determine whether pitting phenomena (often found in passive systems) also occur. One way to do this is to scan significantly anodic of the open-circuit potential, noting the potential where film breakdown occurs, and then scanning backward to determine if the current remains elevated above the original passive current density (cyclic polarization). If the reverse curve intersects the forward curve with significant hysteresis, the hysteresis loop can be quantified and related to how susceptible the material is to pitting and how readily repassivation occurs.

3. Further characterization of tank sludge may be important, particularly if more segment 13R1 type sludges are expected. These sludges showed inordinately high amounts of solids and are difficult to perform electrochemical measurements on. Consequently, it is recommended that prior to further polarization studies on these types of sludges, the electrical properties of these sludges first be characterized. This may be possible using experimental setups similar to that already being employed but with the capacity for alternating current (AC) measurements. High-frequency AC impedance may be useful in characterizing the conductivity of the sludge medium and how it depends on composition and temperature. Knowing this behavior, may allow electrochemical testing even of these very resistive sludge solutions.

4. Electrochemical cell development needs to continue to support electrochemical scans in a hot cell environment. The test cell components and the top design needs improvement. For example, the platinum electrodes need to be spike-like in configuration with a helical groove(s) to increase surface area and remain robust enough to penetrate and be withdrawn from sludge with a minimum of geometry distuption. A machined sample jar/electrochemical cell cover from material such as Rexolite ${ }^{T M^{3}}$ would increase efficiency in mitigation of argon gas leaks, placement and manipulation of working electrodes and the reference/Luggin.

\footnotetext{
${ }^{3}$ Rexolite is a registered trademark of the C-Lec Plastics, Inc; 1717 Bridgeboro Road, Beverly, New Jersey 08010
} 
RPP 12077 Rev, 0

\subsection{REFERENCES}

ASTM, 1999, Standard Reference Test Method for Making Potentiostatic and

Potentiodynamic Anodic Polarization Measurements. Designation G5 - 94

(Reapproved 1999), American Society for Testing and Materials,

West Conshohocken, Pennsylvania.

B-120-D1, 1976, Design Specification for Primary and Secondary Steel Tanks, Project $B-120,241-A W$ Tank Farm, Vitro Engineering Corporation, Richland,

Washington.

Baker, H. L., 2002, "Tank 241-AY-102 Core Samples Analytical Results for the Final Report," (letter FH-0202868 Rev. 0 to G. A. Stanton, CHG, June 25), Fluor Hanford, Richland, Washington.

CHG, 2001a, Tank Waste Information Network System (TWINS), Queried 1/15/02, [Data/Best Basis Inventory/Best Basis Inventory Without Details (rebaselined/in progress)], Internet at http://twins.pnl.gov:8001/twins3/twins.htm

CHG, 2001b, Tank Waste Information Network System (TWINS), Queried 1/15/02, [Measurements/SACS Surface Level], http://twins.pnl.gov:8001/lwins3/twins.htm

CHG, 2001c, Tank Waste Information Network System (TWINS), Queried 1/15/02, [Measurements/SACS Temperatures], http://twins.pnl.gov:8001/twins3/twins.htm

CHG, 2002, "Chemistry Control Program," Tank Farms Technical Safety Requirements, Section 5.15, HNF-SD-WM-TSR-006, Rev. 2l, CH2M HILL Hanford Group, Inc,, Richland, Washington.

FH, 2002, "DSTIP Tank 241-AY-102 Sludge Electrochem Test," Contract 12292, Rclease 64, Fluor Hanford, Inc., Richland, Washington.

Jo, J., R. P. Anantatmula, C. P. Shaw, H. Berman, D. M. Ogden, and M. J. Thurgood, 2002, Technical Basis for Caustic Additions to Tanks 241-AY-101, 241-AY-102, 241-AN-102, and 241-AN-107, RPP-8173, Rev. 1, CH2M HILL Hanford Group, Inc., Richland, Washington.

LO-160-104, 2001, "Core Segment Extrusion Process Using the Hydraulic Extruder," Rev/Mod: D-0, Effective Date: 12/14/01.

O'Connor, J. S., 2002, “Contract No. DE-AC27-99RL14047 - Recovery PIan for Addition of Nitrite to Tank 241-AY-102," (letter 02-TOD-006/0200077 to E. S. Aromi, CHG, January 29), U.S. Department of Energy, Office of River Protection, Richland, Washington. 
Princeton Applied Research, "Basic of Corrosion Measurements," Princeton Applied Research Applied Instruments Group, Oak Ridge, Tennessee http://www.princetonappliedresearch.com/applications/application notes/087.pdf

Rasmussen, J. H. E., 2002, Tank 241-AY-102 Core Sampling and Analysis Plan, RPP-9948, Rev. 0, CH2M HILL Hanford Group, Inc., Richland, Washington.

Stern, M., and A. L. Geary, 1957, "The Shape of Electrochemical Polarization Curves," JElectrochem Society, 104, 56.

Winters, W. I., 2002, "Test Plan/Procedure for Electrochemical Corrosion Testing of A515 Carbon Steel in 241-AY-102 Sludge,"(letter FH-0201937 to K. G. Carothers, CHG, May 3), Fluor Hanford, Richland, Washington. 
RPP 12077 Rev. 0

APPENDIX A

TEST PLAN/PROCEDURE FOR ELECTROCHEMICAL CORROSION TESTING OF A515 CARBON STEEL IN 241-AY-102 SLUDGE 


\section{A1.0 INTRODUCTION}

This test procedure describes the sample extrusion and electrochemical corrosion testing on 241-AY-102 sludge samples. These tests are being performed to evaluate the corrosion characteristics of the carbon steel wall in the knee-region of the double- shell tank where the sludge is in contact. Carbon steel specimens of A515 Grade 60 carbon steel similar to that used in the tank's construction will be used in the measurements. The extrusion and testing are designed to maintain the waste under anaerobic conditions like that found in the bottom of the tank. Extruding the sample and running the tests under a blanket of argon will maintain the anaerobic condition. The tests will utilize potentiodynamic polarization scans to establish such factors as open circuit corrosion potential, Tafel constants, polarization resistance, passivation regions and corrosion rates. The corrosion tests will be carried out at the expected maximum seasonal tank temperature of $60^{\circ} \mathrm{C}$. These tests are patterned after ASTM procedure G5-94, "Standard Reference Test Method for Making Potentiostatic and Potentiodynamic Anodic Polarization Measurements."

Two lower segments from tank 241-AY-102 are being taken to perform these tests. A special extrusion box has been designed to collect and maintain the sample in an argon (Ar) atmosphere during extrusion and storage. The normal pneumatic extrusion system will not be utilized.

Because this is the first time this type of extrusion and electrochemical measurement has been performed on tank sludge material, the steps of this procedure may be modified depending on the conditions of the sample and its electrochemical response. When possible these changes will be communicated to the customer prior to initiating. However, in all cases deviations from the test plan will be documented in laboratory notebooks (HNF-N-2741) and in the final report.

\section{A2.0 QUALITY CONTROL}

The ASTM G-5 procedure with AISI Type 430 stainless steel will be used prior to sample testing to confirm the performance of the electrochemical system and ensure the electrodes and potentiostat instrument are functioning properly. Multiple A515 Grade 60 test specimens will be analyzed to evaluate reproducibility. An oxygen meter will be utilized to ensure the oxygen concentration is minimized during extrusion. Optimization testing for oxygen depletion in the jars used to collect the sludge samples during the extrusions as a function of the flow rate, sparge time, and hood ventilation effects will be evaluated in the 222-SA Laboratory prior to extrusion as demonstrated in trial runs and the results recorded in the controlled laboratory notebook. Evidence that an Ar purge is maintained on the sample jars to achieve near anaerobic conditions during all phases of the electrochemical corrosion testing will be collected. 


\section{A3.0 SAFETY}

Any contact with the working electrode and auxiliary electrode wires can result in electrical shock and/or burns. In the hot cell, this does not represent a personal hazard but could damage equipment. The instrument should always be in the OFF or STANDBY mode during electrode connecting operations.

Sulfuric acid, $1 \mathrm{~N}$, should be handled carefully to avoid getting on the skin or clothing. Any contact with the skin or clothing should be washed immediately with large amounts of water. Any skin irritation from contact should be reported to supervision.

The heating tape should not be allowed to lap over itself and should be kept away from items that may be melted or affected by the heat. Occasional checking of the heating tape during long periods of unattended operation will be performed.

\section{A4.0 WASTE GENERATION}

\section{A4.1 Liquid Waste}

Acid Waste - $1 \mathrm{~N} \mathrm{H}_{2} \mathrm{SO}_{4}$ used in the ASTM standard runs. The acid waste will be kept in a labeled container and tracked using a waste inventory sheet. This waste will be managed in accordance to $11 \mathrm{~A}$ hot cell procedures.

Alkaline Waste - Inhibitor Solution - $0.01 \mathrm{M} \mathrm{NaOH}$ and $0.01 \underline{\mathrm{M}} \mathrm{NaNO}_{2}$, Luggin fill solution $-1 \mathrm{M} \mathrm{NaNO}_{3}$ - This waste will be kept in a separate labeled container and tracked using a waste inventory sheet. This waste will be managed in accordance to 11 A hot cell procedures.

Organle Waste - Ethanol - Ethanol used to clean the specimens outside the hot cell will be stored in a separate labeled container and tracked using a waste inventory sheet. This waste will be managed in accordance to laboratory procedures.

\section{A4.2 Solid Waste}

Stainless steel and carbon steel specimens and holders will be disposed of in the hot cell if they are not removed for microscopic examination. Glass sample jars may be disposed of after a reasonable holding period.

\section{A5.0 REAGENTS}

Sulfuric Acid - $1 \mathrm{~N}$ - Dilute $27.8 \mathrm{~mL}$ of $98 \% \mathrm{H}_{2} \mathrm{SO}_{4}$ in $1 \mathrm{~L}$ of deionized water. Store in glass. Label container with content, date and expiration date (1 year).

Argon Gas - High purity with no oxygen. 
Inhibitor Solution - $0.01 \underline{\mathrm{M} \mathrm{NaOH}}$ and $0.01 \underline{\mathrm{M} \mathrm{NaNO}} 2$ - Prepare just before use and store in plastic. Replace after 2 months.

Ethanol - Reagent grade - Steel specimen cleaning reagent.

$1 \underline{\mathrm{M} \mathrm{NaNO}} \mathrm{N}_{3}$ - Luggin tube filling solution

\section{A6.0 EQUIPMENT}

Extrusion Box - Box consist of plastic skirt and two sample jar-holding plates for positioning the sample jar. A third plate will position the core sampler over the sample jar. A core sampler collar covers the inlets to the box and is equipped with a fitting to connect to the Ar supply. This arrangement is used to direct Ar down into the sample jar prior to and during the extrusion.

Oxygen Meter - Matheson-Trigas Oxygen Deficiency Meter, Model number 8061 Meter monitors oxygen in the extrusion box during the extrusion process.

Reference Electrode -Radiometer Model Number B20B110 Standard Calomel Electrode

Luggin Tubes - Interface for reference electrode and measurement solution. Bridged with $1 \underline{\mathrm{M}} \mathrm{NaNO}_{3}$ solution.

Auxiliary Electrode - AESAR Model number 20319, 124 mm- Platinum coil electrode with glass insulator.

Working Electrode Holder - 316 Stainless steel rod with glass insulator and Teflon gaskets and seals.

Working Electrode for ASTM G5 Method- Type 430 Stainless steel cylinder with surface area of $5.64 \mathrm{~cm}^{2}$ polished to ASTM requirements. Metal Samples, Mumford Alabama, Number $430 E L 410$.

Working Electrode for 241-AY-102 Samples-Type 515A Grade 60 Carbon Steel cylinder with surface area of $5.64 \mathrm{~cm}^{2}$ polished to ASTM requirements. Metal Samples, Mumford, Alabama, Number 515A 60EL410.

Cell Jar with Rubber Lids - 500-mL wide mouth glass jar fitted with either (1) rubber stopper with argon gas inlet and outlets with shut off or (2) rubber stopper with 2 counter electrode holes, 1 reference electrode hole, 1 working electrode hole, Ar gas inlet and outlets and a temperature probe hole.

Potentiostat - PAR model 273 with data collection and reduction software. 
Temperature probe - Monitor temperature of sludge sample in cell jar, using T-type thermocouple, 12-ft length, (Eustis $\mathrm{Co}$, Inc. \& Pyrocom), coated with fluorinated ethylene propylene (FEP) shrink wrap.

Heating tape - Thermolyne, 2" x 48" heat belt, Model Number BS0201-040, with OMEGA Temperature controller pre-set to $60^{\circ} \mathrm{C}$.

\section{A7.0 PROCEDURE STEPS}

\section{Part A - Extrusion}

1.0 Prepare core sampler for extrusion, per instruction in Section 6.1.6 of LO-160-104.

2.0 Position extruder box in position to receive sampler.

3.0 Place clean $500 \mathrm{~mL}$ jar in the extrusion box to receive sample.

4.0 Place the oxygen sensor head in the bottom of the box and turn oxygen meter on.

5.0 Place core sampler on top of extrusion box with collar tight against the box. Fix sampler in place with manipulator.

6.0 Turn on Ar gas with a high flow. Note time of start; am/pm and gas flow as a function of valve position and gage psi, Appendix A.

7.0 Refer to standard graph for oxygen to attain $<1$ percent, allow gas to flow for another 2 minutes before starting extrusion in Step 9.

8.0 Monitor the oxygen meter for possible air intrusion and record readings during process.

Note: If the core sampler valve is opened all the way the sampler piston end may fall into the sample jar. This will interfere with the electrochemical measurements and retrieving the end piece could introduce oxygen into the siudge sample.

9.0 Partially open core sampler valve to initiatc extrusion of sample. (DO NOT turn valve completely OPEN).

10.0 Begin to slowly push core sampler rod down to extrude sludge sample. Check to be sure sludge sample is cleanly entering the jar.

11.0 Continue to monitor oxygen levels and compensate if oxygen levels rise.

12.0 Remove core sampler when all of the sludge sample has been extruded. Leavc collar in place to continue to purge with argon.

Note: Prepare rubber lid with argon connections and shut off valves. Direct Ar stream into jar while placing stopper on jar. 
13.0 Remove top plate from extruder box while continuing to flood the jar surface with Ar and immediately stopper the jar.

14.0 Purge the sample jar with a low flow of Ar gas and shut off valves.

15.0 Remove sealed jar from extrusion box and photograph sludge if good photo is possible.

16.0 Transport the sealed jar to Cell 3 for electrochemical measurement.

17.0 Clean up extruder and equipment per LO-160-104, Section 6.4

Note: A decision on how to maintain Ar gas flow during extended sfabilization and analysis times will be made based on the dryness of the sludge. If the sludge is dry then the Ar gas will be turned off and applied intermittently (based on tests of air intrusion into the sealed cell) to avoid drying the sample out from continued purging. If the sample is wet, a very slow flow of Ar (several bubbles per minute) will be maintained over the sample during the entire test assuming there is no indication of excessive drying.

18.0 Reconnect the jar in Cell 3 to Ar and continue to purge intermittently or continually with a low flow of Ar.

Note: Decide if the second segment will be extruded at this time or after the analysis of the first segment. Decision will depend on (1) the confidence that second sampler is full, (2) the success of the first extrusion and need for improvements (3) which storage method will be the most anaerobic, and (4) the potential of sample drying.

\section{Part B - Electrochemical Testing}

Note: All specimens are stored in corrosion inhibitor paper prior to use. The specimens are washed in ethanol and dried to remove oil residues. The specimens are assembled on holders outside the hot cell and rewrapped in inhibitor paper just prior to introducing into the hot cell for analysis.

1.0 Perform an ASTM test using 430 stainless steel (SS) working electrode and $1 \mathrm{~N} \mathrm{H}_{2} \mathrm{SO}_{4}$ on the electrochemical cell to check operational condition.

(a) Fill the clean $500 \mathrm{~mL}$ cell with $1 \mathrm{~N} \mathrm{H}_{2} \mathrm{SO}_{4}$.

(b) Place calomel reference electrode in the cell system.

(c) Place a $430 \mathrm{SS}$ specimen into the cell system.

(d) Begin Ar purge of the cell.

(e) Allow the specimen to equilibrate 1 hour.

(f) Run a potentiodynamic scan of the specimen under ASTM conditions.

Note: Check the electrode cell response against standard ASTM potentiodynamic scan. Proceed with step 2 only when a satisfactory ASTM scan is obtained indicating proper electrochemical cell response (see Figure A-1) 
2.0 Rinse electrode system off with deionized water before proceeding to analyze 241-AY-102 sludge and reconfigure electrode system for alkaline waste testing.

Note: Prepare rubber sample lid with Calomel reference electrode with 1 M $\mathrm{NaNO}_{3}$ in Luggin tube and an A515 Grade 60 working electrode (see Figure A-2). Place heating tape around jar (see Figure A-3).

3.0 Remove rubber storage lid from the sample jar and immediately replace with rubber electrode lid.

4.0 Do not insert the reference electrode until necessary.

5.0 Adjust Ar gas flow to slowly blanket the waste with Ar.

Note: The first specimen will be analyzed at ambient temperature. This will reduce the potential for losing data from temperature effects (bubble formation, electrode frit fallure, etc.) on the electrode system or losing sample integrity because of drying out. The second and third specimens will be run at $60^{\circ} \mathrm{C}$ assuming excessive drying does not occur.

Note: Omit Step 6 for the first specimen. Use Step 6 for second and third specimens.

6.0 Turn on the heating tape and allow the sample to come to $60^{\circ} \mathrm{C}$.

Note: Any excessive drying may require heating to be discontinued and the test run at a lower temperature. In addition, If testing indicates that heating affects the electrochemical response (induced nolse or current) then heating will be turned off before making the measurement.

Note: Ensure potentiostat is in the standby mode.

7.0 Connect all the electrode leads to the cell and turn the potentiostat $\mathrm{ON}$.

8.0 Allow the specimen to come to equilibrium for 18-24 hours or until the corrosion potential has stabilized. Record $\mathrm{E}_{\mathrm{eor}}$ vs, time and collect data (PAR software program).

Note: Stabilization time may be varied depending on electrode response or because of operational limitations such as times required to complete scanning.

9.0 Record stabilization time temperature hrs and corrosion potential $\mathrm{mV}$ and

10.0 Set patentiostat parameters for a lincar polarization plot $\left(\mathrm{E}_{\mathrm{cor}}+/-20 \mathrm{mV}\right)$ to determine polarization resistance and record the plot.

11.0 Set patcntiostat parameters for a Tafel region plot $\left(\mathrm{E}_{\mathrm{nnT}}+/-250 \mathrm{mV}\right)$ to determine Tafel constants and record plot. 
Note: Allow the specimen to equilibrate until $E_{\text {carr }}$ has stabilized before initiating the next step. This time should not exceed an hour.

12.0 Set potentiostat parameters for full potentiodynamic scan $E_{\text {carr }}-300 \mathrm{mV}$ to $+1600 \mathrm{mV}$ and record data and plot.

13.0 Collect scan conditions and data. Plot the potentiodynamic scan for evaluation.

14.0 Place potentiostat in standby mode.

15.0 Remove the working electrode, rinse off with deionized water, and place in inhibitor solution. Save for microscopic evaluation.

16.0 Place a new working electrode into the sample.

17.0 Repeat steps 6 through 16 for the second specimen then repeat the same steps 6 through 15 for a third specimen.

Note: After the analysis of the third specimen, a new specimen may be placed in the waste and allowed to stand in the waste for an extended equilibrium time and evaluated later.

18.0 Plug the working electrode hole with a blank stopper or with a third platinum electrode.

19.0 Disconnect the jumper wire from the platinum counter electrodes; connect one of the platinum electrodes to the working electrode lead, the other to the counter electrode lead.

20.0 Perform a potentiodynamic scan (Step 12) using the Pt electrode as the working electrode after running the 3 test specimens.

Note: A decision on testing the second segment will be made based on (1) if it was used because of insufficient sample in the first segment, (2) observations made during the testing of the first segment (sensitivlty to drying) and (3) stability of sample in sampler for extended time. The test plan may be modified based on the first segment experience.

21.0 Repeat Parts A and B for the second segment.

Part C - Reporting, Deliverables and Follow Up Evaluation

1.0 Transfer the specimens outside the hot cell and remove from holder.

2.0 Store the specimens in inhibitor solution.

3.0 Decontaminate as needed and perform microscopic evaluation of at least one specimen. 


\section{RPP 12077 Rev. 0}

4.0 Prepare Technical Report (SD) with the following outline by June 28, 2002:

- Executive Summary

- Description of Tank 241-AY-102 Waste

- Description of Sample Extrusion

- Photo of sludge

- Photo of extrusion system

- Discussion of oxygen control

- Discussion of any problems

- Description of Electrochemical Testing

- Description of electrochemical cell

- Description of ASTM test results

- Description of synthetic test results

- Description of 241-AY-102 test results

- Scan conditions

- Potentiodynamic scans

- Tafel Constants

- Polarization Resistance Estimates

- $E_{\mathrm{cor}}$

- Passitivity Regions

- Corrosion rate calculations

- Reproducibility evaluations

- Problems

- Microscopic examination results

- Data Evaluation

- Conclusions

- Recommendations

\section{Part C Sample Disposition}

1.0 Samples will be saved until directed for disposal by the customer. 
RPP 12077 Rev. 0

Figure A-1. Potentiodynamic Scan of Stainless Steel 430 in $1 \mathrm{~N} \mathrm{H}_{2} \mathrm{SO}_{4}$

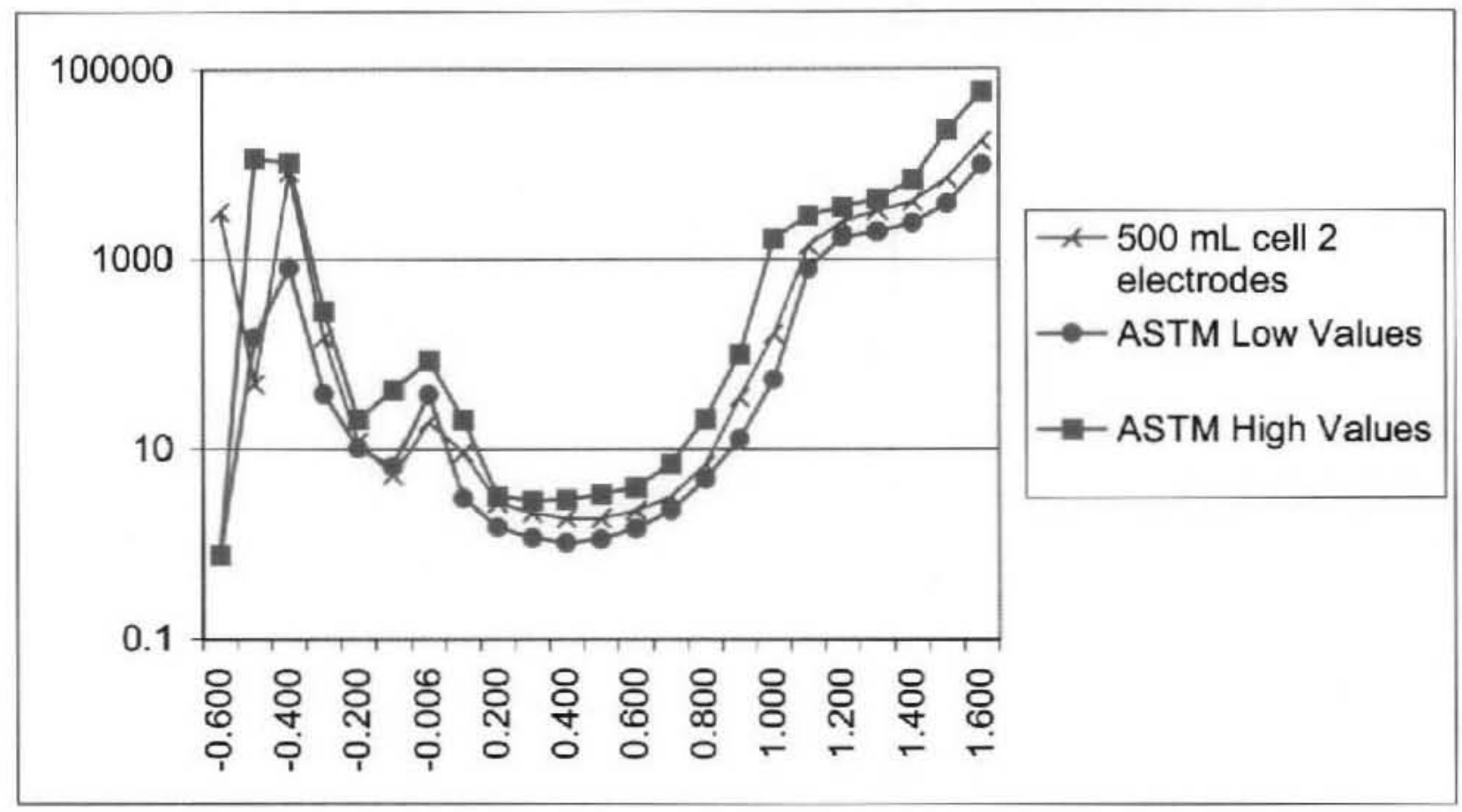

\begin{tabular}{|c|c|c|c|c|c|c|c|c|c|c|c|}
\hline $\begin{array}{l}8 \\
8 \\
0\end{array}$ & $\begin{array}{l}8 \\
\text { ச } \\
\text { : }\end{array}$ & $\begin{array}{l}\text { O্ } \\
\text { ஸ̣ }\end{array}$ & $\begin{array}{l}\text { ஜ } \\
\end{array}$ & $\begin{array}{l}\text { 오 } \\
\text { O }\end{array}$ & ᄋ̊ & $\begin{array}{l}8 \\
0 \\
0 \\
0\end{array}$ & $\begin{array}{l}8 \\
0 \\
\infty \\
0\end{array}$ & 용 & ঃ্ণ & $\begin{array}{l}\text { O } \\
\text { f́ } \\
\end{array}$ & 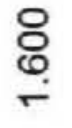 \\
\hline
\end{tabular}


RPP 12077 Rev. 0

Figure A-2A. Cell Diagram Top

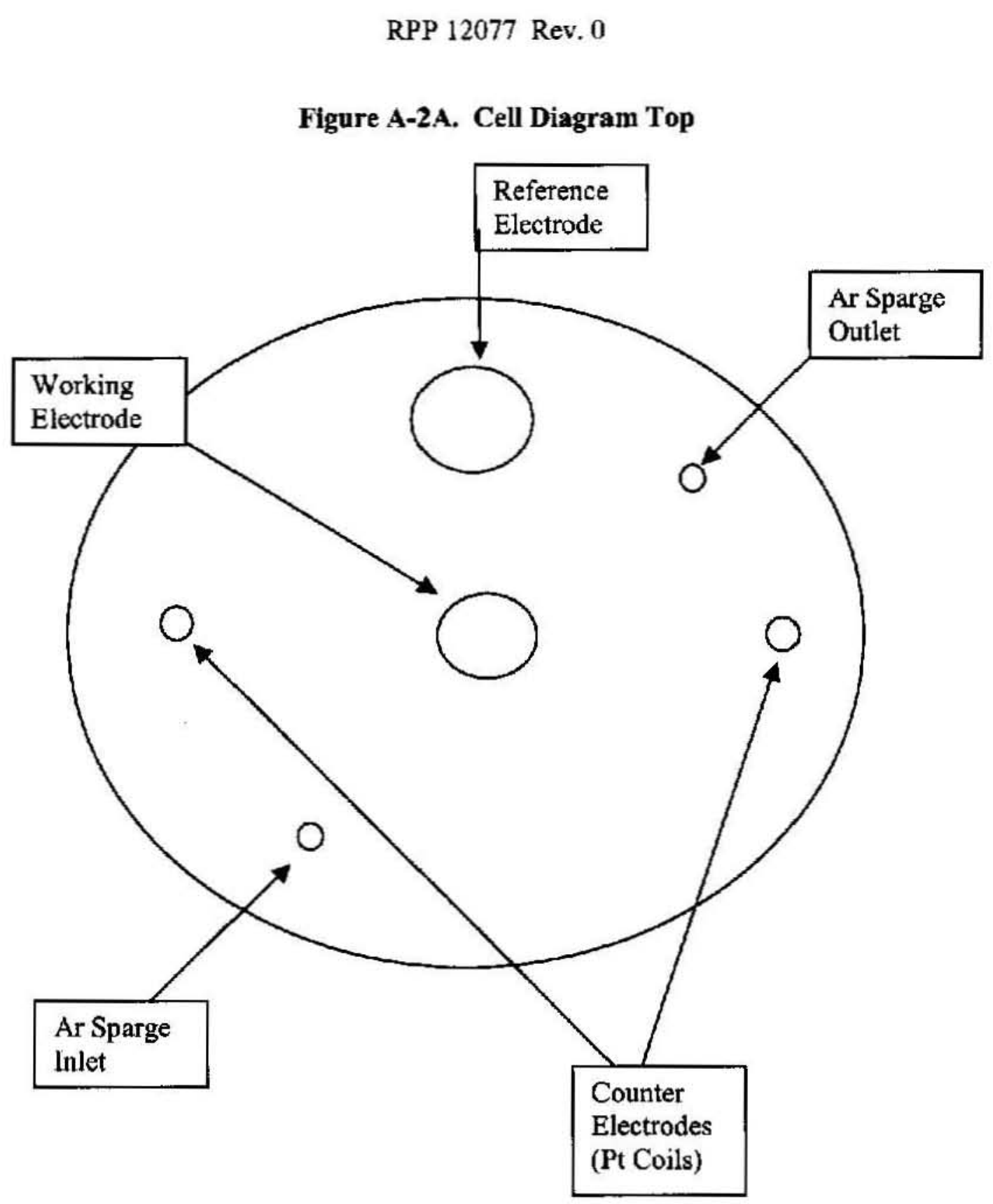


RPP 12077 Rev. 0

Figure A-2B. Cell Diagram - Side View

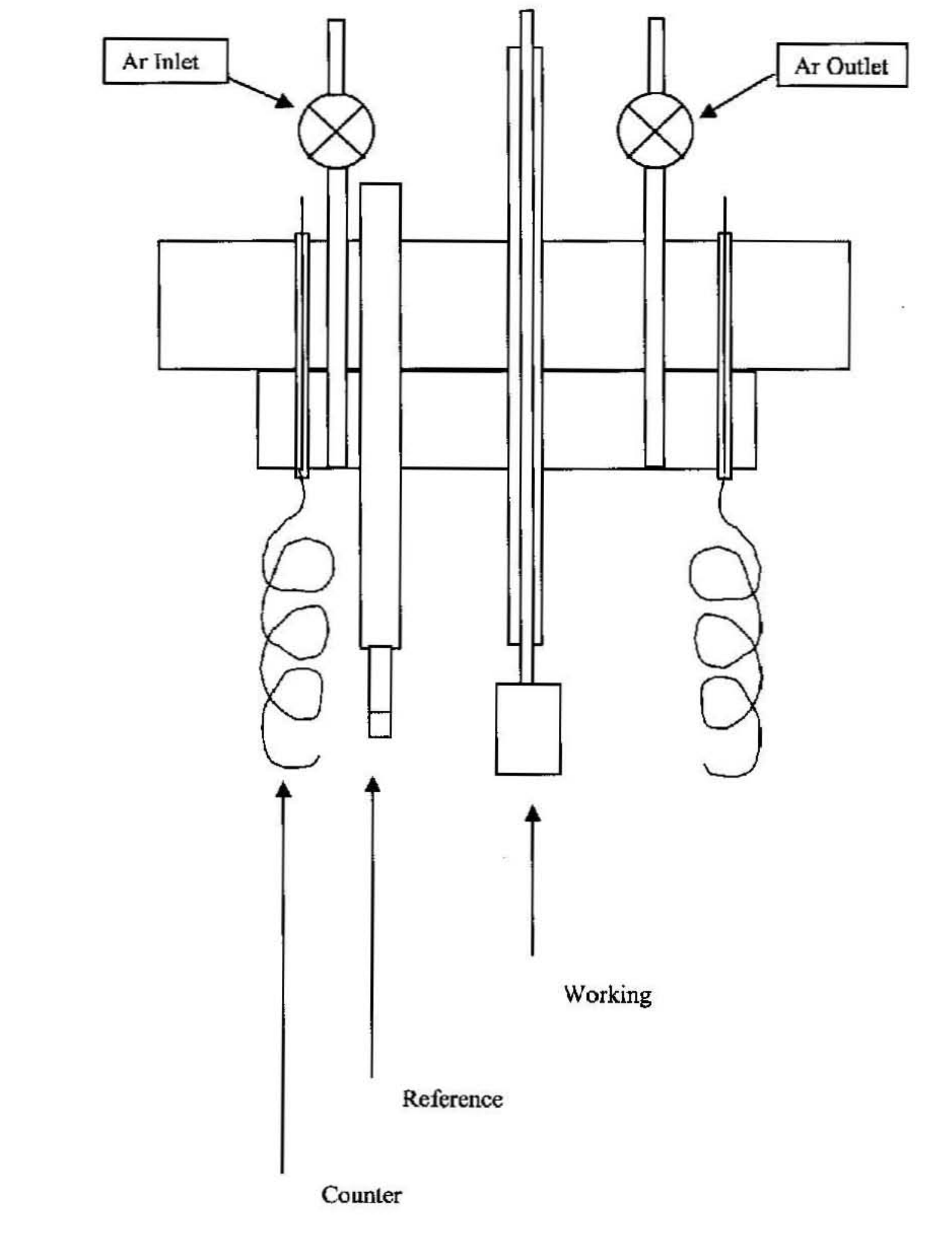

Counter

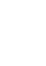


RPP 12077 Rev. 0

Figure A-3. Heating Tape Configuration on Cell

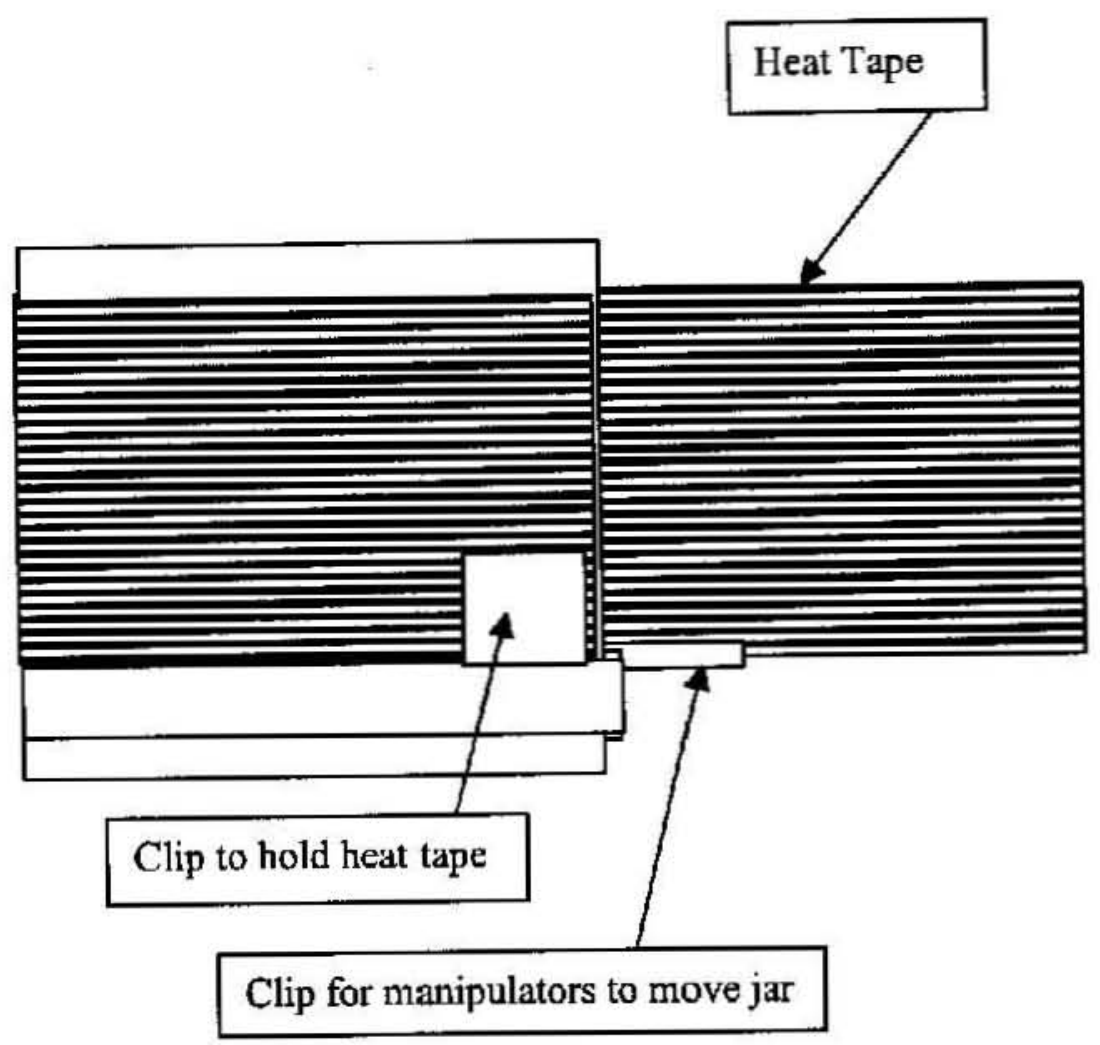


RPP 12077 Rev. 0

\section{Appendix A}

Work Sheet

Argon Gas Flow During Extrusion

\begin{tabular}{|c|c|c|c|}
\hline Time (seconds) & Valve Position & Psi Gage & \% Oxygen \\
\hline 0 & & & 21.9 \\
\hline & & & \\
\hline & & & \\
\hline & & & \\
\hline & & & \\
\hline & & & \\
\hline
\end{tabular}


RPP 12077 Rev. 0

\section{Appendix B}

Work Sheet

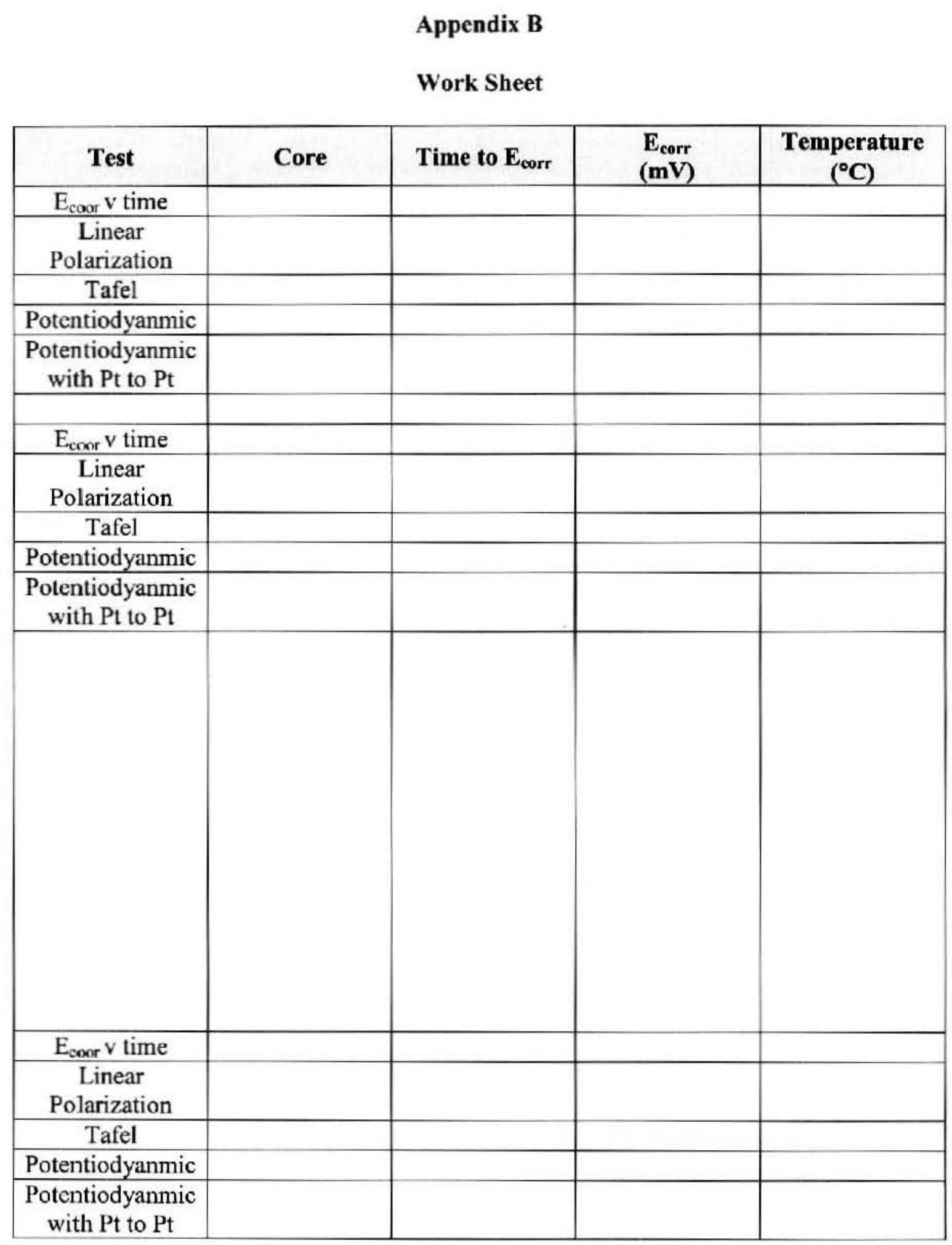

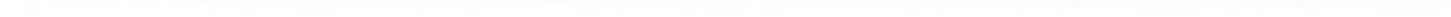

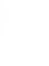

A-15

.

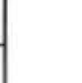


Page 73 of 99 of D0130772

RPP 12077 Rev. 0

APPENDIX B

CORE SEGMENT DESCRIPTIONS 
RPP 12077 Rev. 0

\section{AY-102 CORE 300 SEGMENT 13R1 RISER 57}

Date Extruded: $\quad 05 / 01 / 02$

Sample Number: $\quad 300-13 \mathrm{R} 1$

Cask SN: $\quad 14 \mathrm{G}$

Logbook : $\quad$ WHC-N-1346(2)

LABCORE ID: $\quad$ S02T000866

\section{EXTRUSION INFORMATION}

Liner Liquid: $\quad 70 \mathrm{~mL}$ total -retained $50 \mathrm{~mL}$ (Jar $\$ 18938$ )

Drainable Liquid: None

Solid Sample: Collected approximately $50 \mathrm{~mL}$ out of $70 \mathrm{~mL}$ of liner liquid. There was a chunk of solids on the end of the sampler that was not retained. Extruded approximately 16 inches of wet sludge (D3) that was dark brown. Solids were collected in an inert argon filled jar. Because of the configuration of the vertical extrusion, collecting a net weight of the sample could not be taken.

Approximately $200-\mathrm{mL}$ volume was collected.

\section{SUBSAMPLE INFORMATION}

Liner Liquid: $\quad 50 \mathrm{~mL}$

Drainable Liquid: $\quad$ n/a

Segment Solids: Approximately $200-\mathrm{mL}$ volume

Total Sample Mass: Approximately $200-\mathrm{mL}$ volume 


\title{
AY-102 CORE 300 SEGMENT 13BR RISER 57
}

\author{
Date Extruded: $\quad 05 / 28 / 02$ \\ Sample Number: $\quad 300-13 B R$ \\ Cask SN: $\quad 7 \mathrm{G}$ \\ Logbook : $\quad$ WHC-N-1346(2) \\ LABCORE ID: $\quad$ S02T000868

\section{EXTRUSION INFORMATION}

Liner Liquid: $\quad 40-\mathrm{mL}$ total. Did not retain

Drainable Liquid: None

Solid Sample: Extruded approximately $200 \mathrm{~mL}$ of brown solids. The solids were wet sludge (D3) in texture and were collected for corrosion study.

\section{SUBSAMPLE INFORMATION}

Liner Liquid: $\quad$ n/a

Drainable Liquid: $\quad \mathrm{n} / \mathrm{a}$

Segment Solids: Jar: 19463

Total Sample Mass: Approximately $200-\mathrm{mL}$ volume. Could not weigh. 


\section{AY-102 CORE 300 SEGMENT 13R RISER 57}

$\begin{array}{ll}\text { Date Extruded: } & 05 / 28 / 02 \\ \text { Sample Number: } & 300-13 \mathrm{R} \\ \text { Cask SN: } & 19-\mathrm{G} \\ \text { Logbook: } & \text { WHC-N-1346 }(2) \\ \text { LABCORE ID: } & \text { S02T000865 } \\ \text { EXTRUSION INFORMATION }\end{array}$

Liner Liquid: $\quad 15 \mathrm{~mL}$. Did not retain

Drainable Liquid: None

Solid Sample: Collected approximately $250 \mathrm{~mL}$ of brown, sludge slurry (D2) added to AY-102 C300 Segment \# 13BR in jar \# 19463 for a total of $450 \mathrm{~mL}$. Approximately $40 \mathrm{~mL}$ were discarded to drain.

\section{SUBSAMPLE INFORMATION}

Limer Liquid: $\quad 15 \mathrm{~mL}$. Did not retain

Drainable Liquid: $\quad$ n/a

Segment Solids: Approximately 250-mL volume. Jar: 19463

Total Sample Mass: Approximately $250-\mathrm{mL}$ volume. Could not weigh. 
Page 77 of 99 of $\mathrm{D} 0130772$

RPP 12077 Rev. 0

\section{APPENDIX C}

DATA SUMMARY AND OPPORTUNISTIC ANALYTE RESULTS

C-1 
Data Summary and Opportunistic Analyte Results (Baker 2002)

\begin{tabular}{|c|c|c|c|c|c|c|c|c|c|c|c|}
\hline \multicolumn{12}{|l|}{ Appendix } \\
\hline $\mathrm{AY} 102 \mathrm{CC} 1$ & & & & & & & & & & & \\
\hline \multicolumn{12}{|c|}{ Data Sumnary and Opporturistic Analyc Resulls } \\
\hline & & & & & & & & & & & \\
\hline CORE NUMBER & 300 & & & & & & & & & & \\
\hline SEGMENT \# & 13 & & & & & & & & & & \\
\hline SEGMENT PORTION & Drainx & ble Liquid (Total) & & & & & & & & & \\
\hline Samplet R & A* & Annlyte & Unit & Stundard \% & Blank & Result & Duplicate & Average & RPD \% : & Spk Rec $\%$ & Det Lirnit \\
\hline S02T000861 & & Drainable Liquid Recovrd - Vol & $\operatorname{tmI}$. & $n / \mathbf{a}$ & $n / a$ & 0 & $\mathrm{n} / \mathrm{a}$ & n/a & $\mathrm{n} / \mathrm{a}$ & n/a & $n / a$ \\
\hline S02T000861 & & Organic Vol Present / hotcell & $\mathrm{mL}$ & $n / a$ & $\pi / a$ & 0 & $n / a$ & $\pi^{\prime} / \mathrm{H}$ & $\mathrm{n}^{\prime} \mathbf{u}$ & n/a & $n / a$ \\
\hline SEGMENT PORTION & Segme & ant Solids (Centrifuged Solids Portion) & & & & & & & & & \\
\hline Sample\# $\mathbf{R}$ & A* & Anulyte & Unit & Standard \% & Blank & Result & Duplicate & Average & RPD \% : & Spk Rec $\%$ & Det Limit \\
\hline S02T000911 & & Bulk Density or Sample & $g / m L$ & $n / a$ & n/a & 1.61 & $n / a$ & $n / a$ & $n / 1 / 1$ & $\pi / a$ & 0.5 \\
\hline S02T000911 & & Solids Recovered - Volume & $\mathrm{mL}$ & n/a & $\mathrm{n} / \mathrm{a}$ & 74 & n/a & $n / a$ & $n / a$ & $n / \mathbf{a}$ & 0.1 \\
\hline S02T000911 & & Solids Recovered - Weight & 8 & n/a & $n / a$ & 119 & $n / a$ & $n / a$ & $n / a$ & $n / \mathbf{a}$ & 0.01 \\
\hline SO2T000920 & & $\%$ Water by TGA using $T A$ & $\%$ & 98.1 & $n / a$ & 48 & 46.4 & 47.2 & 3.28 & $n / a$ & $n / a$ \\
\hline 5027000920 & & TIC by Acid/Coulometry & $\mu g / g$ & 92.3 & 2.6 & $8.71 E+03$ & $9.32 \mathrm{E}+103$ & $9.02 \mathrm{E}+03$ & 6.77 & 101 & $s$ \\
\hline $502 \mathrm{~T} 000920$ & & TOC by Persulfate/Coulometry & $\mu g / g$ & 96 & 0.6 & 1.23E+04 & $1.26 \mathrm{E}+04$ & $1.24 E+104$ & $2.4 \mathrm{l}$ & 93.8 & 40 \\
\hline $502 T 000923$ & $\Lambda$ & Silver -ICP-Acid Digest & $\mu g / g$ & 100 & $<0.0100$ & 551 & 508 & 530 & 8 & 97.4 & 5 \\
\hline 5027000923 & A & Aluminium - ICP-Acid Digest & $\mu \mathrm{g} / 8$ & 104 & 40.0500 & 4.70E+04 & $4.335+04$ & $4.51 \mathrm{E}+04$ & 8.24 & 424 & $1.30 \mathrm{t}+02$ \\
\hline S02T000923 & A & Arsenic-ICP-Acid Digest & $\mu \mathrm{g} / \mathrm{g}$ & 117 & $<0.100$ & $<\$ 0.2$ & $<46.4$ & $\pi / a$ & $n / a$ & III & so \\
\hline
\end{tabular}




\begin{tabular}{|c|c|c|c|c|c|c|c|c|c|c|c|}
\hline SEGMENT PORTION & Seg & nt Solids (Conmrifuged Solids Portion) & & & & & & & & & \\
\hline Sanple\# $\mathbf{R}$ & A* & Analyte & Unit & Standard \% & Bank & Kesult & Deplloate & Average & RPD $\%$ & Spk Rec \% & Det Limit \\
\hline S02T000923 & A & Bonon-ICl'-Acid Digest & $\mu \mathrm{g} / \mathrm{g}$ & 97.7 & $<0.0500$ & 25.6 & $<23.2$ & na & $n / a$ & 99.7 & 25 \\
\hline $502 \mathrm{r} 000923$ & A & Barium -ICP-Acid Digest & $\mu \mathrm{g} / \mathrm{g}$ & 99.8 & $<0.0500$ & $1.53 \mathrm{E}+03$ & $1.46 \mathrm{E}+03$ & $1.49 \mathrm{E}+03$ & 4.8 & 102 & 25 \\
\hline $502 T 000923$ & A & Beryllium-ICP-Acid Digest & $\mu \mathrm{g} g$ & 102 & $<5.00 x-03$ & $<2.51$ & $<2.32$ & $\pi / y$ & $\mathrm{r} / \mathrm{a}$ & 100 & 2.5 \\
\hline S02T000923 & $A$ & Bismuth -ICP-Acid Digcst & $\mu \mathrm{g} / \mathrm{g}$ & 98.9 & $<0.100$ & 138 & 143 & 141 & 3.43 & 101 & 50 \\
\hline $\mathrm{S} 02 \mathrm{~T} 0000923$ & A & Calsium-ICP-Acid Digest & $\mu \mathrm{g} / \mathrm{g}$ & 107 & $<0.100$ & $1.00 \mathrm{E}+04$ & $1.03 E+04$ & $1.06 E+04$ & 5.88 & 112 & 50 \\
\hline $502 \mathrm{~T} 000923$ & $A$ & Cadmium-ICP-Acid Digest & $\mu \mathrm{g} / \mathrm{g}$ & 98.4 & $<5,00=-03$ & 384 & 405 & 395 & 5.2 & 101 & 2.5 \\
\hline S02T000923 & $A$ & Cerium -ICP-Acid Digest & $\mu g / g$ & 100 & $<0.100$ & $1.87 \mathrm{E}+03$ & $1.77 \mathrm{E}+03$ & $1.82 \mathrm{E}+03$ & 5.36 & 102 & 50 \\
\hline S02T000923 & A & Coball -ICP-Acid Digest & $\mu g / g$ & 99.7 & $<0.0200$ & 36.4 & 33.4 & 34.9 & 8.44 & 101 & 10 \\
\hline S02T000923 & A & Chromium-КP-Acid Diges! & $\mu \mathrm{g} / \mathrm{g}$ & 101 & $<0.0100$ & $3.28 \mathrm{E}+03$ & $3.08 E+03$ & $3.18 \mathrm{E}+03$ & 6.07 & 101 & 5 \\
\hline $502 \mathrm{~T} 000923$ & A & Copper-ICP-Acid DigesI & ugig & $10 !$ & $<0.0100$ & 353 & 336. & 344 & 4.9 & 102 & 5 \\
\hline 5021000923 & A & Europium ICP-Acid Digest & $\mu \mathrm{g} / \mathrm{g}$ & 98.6 & $<0.100$ & $<50.2$ & $<46.4$ & $n / a$ & $n / \mathbf{a}$ & 99.3 & 50 \\
\hline 5021000923 & A. & Iron -ICP-Acid Digest & $\mu g / g$ & 98.8 & $<0.0500$ & $1.23 \mathrm{E}+05$ & $9.03 \mathrm{E}+104$ & $1.07 \mathrm{E}+05$ & 30.7 & -541 & 25 \\
\hline S02 T000923 & A & Potassium -ICP-Acid Digest & $\mu \mathrm{g} g$ & 98.5 & $<0.500$ & 754 & 017 & 688 & 20 & 97.2 & $2.50 \mathrm{E}+02$ \\
\hline $502 T 000923$ & A & Lanthanum -ICP-Acid Digest & $\mu \mathrm{g} / \mathrm{k}$ & 101 & $<0.0500$ & $3.10 \mathrm{E}+0.3$ & $2.94 \mathrm{E}+03$ & $3.02 \mathrm{E}+103$ & 5.15 & 101 & 25 \\
\hline $502 \mathrm{TOM09} 23$ & $A$ & Lithium -ICP-Acid Digest & $\mu g / \mathrm{g}$ & 1011 & $<0.0100$ & 59.1 & 55.5 & 57.3 & 6.31 & 102 & 5 \\
\hline 5027000923 & $\Lambda$ & Magnesium - KCP-Acid Digest & $\mu g / \mathrm{g}$ & 97.1 & $<0.100$ & $4.44 E+03$ & $4.21 E+03$ & $4.33 E+03$ & 5.42 & 105 & 50 \\
\hline SO2T000923 & A & Manganese - ICP-Acid Digest & $\mu \mathrm{g} g$ & 97.3 & $<0.0100$ & $1.38 \mathrm{E}+04$ & $1.31 \mathrm{E}+04$ & $1.35 E+04$ & 5,14 & 119 & 5 \\
\hline S02T000923 & A & Molybdenum -KCP-Acid Digest & $\mu g / g$ & 101 & $<0.0500$ & $<25.1$ & $<23.2$ & $\mathbf{n} / \mathbf{a}$ & $n^{\prime} \mathbf{a}$ & 102 & 25 \\
\hline $502 \mathrm{~T} 000923$ & A & Sodium -ICP-Acid Digest & $\mu g / g$ & 100 & $<0.100$ & $5.56 \mathrm{E}+04$ & $5.12 \mathrm{E}+0 \mathrm{~A}$ & $3.34 E+04$ & 8.26 & 60.3 & $2.50 \mathrm{E}+02$ \\
\hline$\$ 02 \mathrm{~T} 000923$ & A & Neodymium-ICP-Acid Digest & $\mu \mathrm{g} / \mathrm{g}$ & 101 & $<0.100$ & $2.87 \mathrm{E}+0.3$ & $2.73 \mathrm{E}+03$ & $2.80 \mathrm{E}+03$ & 4.95 & 101 & 50 \\
\hline $502 T 000923$ & A & Nickel -KCP-Acid Diges! & $\mu \mathrm{g} / \mathrm{g}$ & 99.5 & $<0.0200$ & $3,36 \mathrm{E}+03$ & $3.17 \mathrm{E}+03$ & $3.26 \mathrm{E}+03$ & 5.71 & 90.2 & 10 \\
\hline $502 \mathrm{~T} 000923$ & A & Phosphorus -ICP-Acid Digest & $\mu g / \underline{\underline{R}}$ & 97.9 & $<0.200$ & $5.11 \mathrm{E}+03$ & $4.83 \mathrm{E}+03$ & $4.97 \mathrm{E}+03$ & 5.77 & 344 & $1.00 \mathrm{E}+02$ \\
\hline 5027000923 & A & Lead-K.P-Acid Digest & $\mu g / \underline{g}$ & 97.7 & $<0.100$ & $4.92 \mathrm{E}+03$ & $4.61 \mathrm{E}+03$ & $4.77 \mathrm{E}+133$ & 6.53 & 8B.9 & 50 \\
\hline
\end{tabular}




\begin{tabular}{|c|c|c|c|c|c|c|c|c|c|c|c|}
\hline SEGMENT POKTION & Seg & ent Solids (Centrifuged Solids Portion) & & & & & & & & & \\
\hline Sample\# $\mathbf{R}$ & A* & Analyte & Linit & Skanderd $\%$ & ftank & Resmli & Duplicate & Aversge & APD \% & Spk Rec \% & Det Limit \\
\hline S02T000923. & $A$ & Sulfur -ICP-Acid Digest & $\mu \frac{g}{g}$ & 10] & $<0.100$ & 730 & 698 & 714 & 4.46 & 105 & 50 \\
\hline 5027000923 & A & Antimany - [CP-Acid Dizest & $\mu \mathrm{g} / \mathrm{g}$ & 98.1 & $<0.0600$ & $<30.1$ & $<27.9$ & $n / a$ & $\mathbf{n} / \mathbf{a}$ & 99.8 & 30 \\
\hline $502 \mathrm{~T} 000923$ & A & Selenium-1CP-Acid Digest & $\mu g^{\prime g}$ & 99.4 & $<0.100$ & $<50.2$ & $<46.4$ & $n / a$ & $\mathrm{n} / \mathrm{a}$ & 86.7 & 50 \\
\hline $502 T 000923$ & A & Silicon-KCP-Acid Digest & $\mu \alpha \dot{y}$ & 95.3 & $<0.0500$ & $2.54 E+04$ & $2.39 \mathrm{E}+04$ & $2.46 \mathrm{E}+04$ & 5.89 & 79.6 & 25 \\
\hline SO2T000923 & A & Samarium-ICP-Acid Digest & He/g & 104 & $<0.100$ & 503 & 477 & 490 & 5.32 & 104 & 50 \\
\hline $502 \mathrm{~T} 000923$ & A & Strontium-КCP-Acid Digest & $\mu \mathrm{E}^{\prime} \mathrm{g}$ & 100 & $<0.0100$ & 350 & 333 & 342 & 5.06 & 100 & 5 \\
\hline$\$ 02 \mathrm{~T} 000923$ & A & Thorium-ICP-Acid Digest & $\mu g^{\prime} g$ & 103 & $<0.100$ & 836 & 891 & 864 & 6.28 & 108 & 50 \\
\hline $502 T 000923$ & A & Titanium-KCP-Acid Digest & $\mu \mathrm{g} / \mathrm{s}$ & 98.7 & $\$ 0.0100$ & 182 & 173 & 178 & 5.52 & 99.8 & 5 \\
\hline S02T000923 & A & Thallium -ICP-Acid Digest & $\mu \mathrm{g} / \mathrm{g}$ & $n / 3$ & $<0.200$ & $<100$ & 643 & $\mathrm{n} / \mathrm{a}$ & n/a & $n / \mathbf{a}$ & $1.00 E+02$ \\
\hline S02T000923 & A & Uranium -ICP-Acid Diges: & $\mu \mathrm{g} / \mathrm{g}$ & 94.2 & $<0.250$ & $7.93[+03$ & 7.59E+03 & $7.76 \mathrm{E}+03$ & 4.46 & $\pi / \mathbf{a}$ & $1.30 \mathrm{E}+02$ \\
\hline $502 T 000923$ & A & Vanadium-ICP-Acid Digest & $\mu \mathrm{g} / \mathrm{g}$ & 101 & $<0.0500$ & 25.1 & $<23.2$ & $n / 2$ & n/a & 97.5 & 25 \\
\hline S02T000923 & A & Yttrium-KP-Acid Digest & $\mu \mathrm{g} / \mathrm{g}$ & 101 & $<0.0100$ & 134 & 127 & 131 & 5.47 & 103 & 5 \\
\hline \$02T000923 & A & Linc-KCH-Acid Digest & $\mu \mathrm{g} / \mathrm{g}$ & 95.5 & $<0.0100$ & 305 & 286 & 296 & 6.45 & 98.9 & 5 \\
\hline $\mathrm{S} 02 \mathrm{~T} 000923$ & A & Zircunium -ICP-Acid Digest & $\mu \mathrm{g} / \mathrm{g}$ & 101 & 80.0100 & 124 & II7. & 120 & 5.76 & 481 & 5 \\
\hline SEGMENT PORTION & Seg & nt Solids (Interstitial Liquid) & & & & & & & & & \\
\hline Sumple\# R & Af & Astalyte & Unit & Stmendard \% & Bank & Resulf & Duplicate & Average & RPD \% & Spk Rec \% & Det Limit \\
\hline$\$ 02 T 000908$ & & Liquid Recovered - Volume & $\mathrm{mL}$ & $n / a$ & n/a & 50 & $n / a$ & $n / a$ & $n / 2$ & $n / a$ & 0.1 \\
\hline $502 T 000908$ & & Liquid Recovered - Wejght & 8 & nia & $n / a$ & 50.4 & n/a & nia & nia & $\pi / 3$ & 0.01 \\
\hline S02 ro00914 & & $\mathrm{OH}$ - by Pot. Titration & $\mu \mathrm{g} / \mathrm{mL}$ & 95.7 < $<2<$ & $<2.50 e+03$ & 302. & nia & nia & $n / a$ & $\mathrm{n} / \mathrm{a}$ & B3 \\
\hline S02T000914 & & pH Direcl & $\mathrm{gH}$ & $n / a$ & $\mathrm{n} / \mathrm{a}$ & 12.1 & n/a & nía & $n / a$ & $n / a$ & 0.01 \\
\hline 5027000914 & & Specific Gravity & $\mathrm{Spg}$ & 100 & $n / a$ & 1.08 & $\mathrm{n} / \mathbf{a}$ & nia & $\mathrm{n} / \mathrm{a}$ & n/a & $1.00[-0]$ \\
\hline S02T000914 & & $\%$ Water by TGA using TA & $\%$ & 98.2 & $\mathrm{n} / \mathrm{a}$ & 92.2 & 92.1 & 92.2 & 0.184 & $\pi / \mathbf{a}$ & $n / \mathbf{a}$ \\
\hline
\end{tabular}




\begin{tabular}{|c|c|c|c|c|c|c|c|c|c|c|c|}
\hline SEGMENT PORTION & Segy & ent Solids (Interstitial Liquid) & & & & & & & & & \\
\hline Sample\# $\mathbf{R}$ & A\# & Anabyte & Unit & Standurd \% & Bdank & Result & Dapliente & Average & APD $\%$ & Spk Rec $\%$ & Def Limit \\
\hline $\mathrm{S} 02 \mathrm{~T} 000914$ & & TIC by Acid/Coulometry & $\mu \mathrm{g} / \mathrm{mL}$ & 99 & 0.3 & $8.88 E+03$ & $n / a$ & $n / \mathbf{a}$ & N/a & $n / a$ & 5 \\
\hline S02T0000914 & & Total Carbon by Coulometry & $\mu g / m L$ & 99.3 & 0 & $1.07 \mathrm{E}+104$ & $n / 2$ & $n / a$ & $n / a$ & n/a & $1.00 \mathrm{E}+02$ \\
\hline SO2T000914 & & Fluoride-KC-Dionex $500 \mathrm{col}$ & $\mu \mathrm{g} / \mathrm{mL}$ & $10 \mathrm{t}$ & 50.0300 & 51.8 & $n / a$ & $n / a$ & $n / 2$ & n/a & 18 \\
\hline S02T000914 & & Glycolate-1C-Dionex 500 ORGACD & $\mu g / m L$ & 103 & $<0.190$ & $<115$ & na & $n / a$ & $n / a$ & n/a & $1.20 \mathrm{E}+02$ \\
\hline $\operatorname{Si2TRXMY14}$ & & Acetate by IC-Dionex $500 \mathrm{col}$ & $\mu g / \mathrm{mL}$ & 102 & $<0.230$ & 598 & $n / 3$ & $n / a$ & $n / 2$ & $\mathrm{~N} / \mathrm{a}$ & $1,40 \pm+02$ \\
\hline S02T000914 & & Formale by IC-TIONFX $500 \mathrm{col}$ & $\mu \mathrm{giml}$. & 102 & $\infty .230$ & $<139$ & $n / 3$ & n/a & $n / \mathbf{a}$ & $i n / \mathbf{a}$ & $1.40 \mathrm{E}+02$ \\
\hline S02T000914 & & Chioride-IC-Dimex $500 \mathrm{col}$ & $\mu \mathrm{g} / \mathrm{mL}$ & 103 & $<0.0460$ & 137 & $n / 2$ & $n / a$ & $n / a$ & $n / a$ & 24 \\
\hline 5021000914 & & Nitrite-IC - Dionex $500 \mathrm{col}$ & 싸mL & 102 & $<0.270$ & $2.26 \mathrm{E}+03$ & $n / 2$ & $n / 2$ & n/a & $n / a$ & $1.60 \mathrm{E}+02$ \\
\hline S02T000914 & & Sulfate-lC-Dimex $500 \mathrm{col}$ & $\mu \mathrm{g} / \mathrm{mL}$ & 101 & $<0.320$ & 743 & $n ; a$ & $n / a$ & $n / a$ & $n / \alpha$ & $1.90 \mathrm{E}+02$ \\
\hline 8021000914 & & Oxalate-K-Dionex $500 \mathrm{col}$ & $\mu \mathrm{gimL}$ & 103 & $<0.270$ & $2.02 \mathrm{E}+03$ & $n / \varepsilon$ & $n / a$ & $\mathrm{n} / \mathrm{a}$ & $n / a$ & $1.60 \mathrm{E}+02$ \\
\hline S02 T000914 & & Brumide-IC-Dionex $500 \mathrm{col}$ & $\mu \mathrm{g} / \mathrm{mL}$ & 98 & $<0.290$ & 186 & $n / a$ & $n / a$ & $\mathrm{n} / \mathrm{a}$ & n/a & $1.80 \mathrm{E}+02$ \\
\hline S02T000914 & & Nitrate-IC-Dionex $500 \mathrm{col}$ & $\mu \mathrm{g} / \mathrm{mL}$ & 99.1 & $<0.300$ & $<182$ & $\mathrm{n} / \mathrm{a}$ & $n / a$ & $n / a$ & $\mathrm{n} / \mathbf{a}$ & $1.80 \mathrm{E}+02$ \\
\hline S02T000914 & & Phosphate-KC-Dionex $500 \mathrm{col}$ & $\mu g / m L$ & 100 & $<0.270$ & 891 & n/a & $n / a$ & n/a & $\mathrm{n} / \mathrm{a}$ & $1.60 \mathrm{E}+02$ \\
\hline S02T000917 & B & Silver -ICP-Acid Digest-I.iquid & $\mu g / m L$ & 93.2. & 40.0100 & $<1.00$ & nis & $n / a$ & $n / 3$ & $\mathrm{n} / \mathrm{a}$ & 1 \\
\hline S02T000917 & $B$ & Ahuminium -ICP-Acid Digest-I.iq & $\mu g / m L$ & 109 & $\triangle 0.0500$ & 227 & nia & $n / 2$ & nia & $n / 2$ & 5 \\
\hline S021000917 & $B$ & Arsenic-LCP-Acid Digest-Liq & $\mu \mathrm{g} / \mathrm{mL}$ & 94 & $<0.100$ & $<10.0$ & nia & $n / 2$ & $n / 2$ & $n / 2$ & 10 \\
\hline S02T000917 & B & Bamon-KCP-Acid Digest-Liquid & $\mu \mathrm{g} / \mathrm{mL}$ & 97.2 & $<0.0500$ & 6.87 & $n / a$ & $\mathrm{n} / \mathrm{a}$ & $n / a$ & $\pi / \mathbf{a}$ & $\underline{s}$ \\
\hline S02T000917 & $\mathrm{B}$ & Barium -KCP-Acid Digest-Liquid & $\mu \mathrm{g} / \mathrm{mL}$ & 96.8 & 40.0500 & $<5.00$ & nia & $\mathrm{n} / \mathrm{a}$ & $\mathrm{n} / \mathrm{a}$ & $n / \mathrm{a}$ & $s$ \\
\hline $502 T 000917$ & $\mathrm{~B}$ & Betyllium -KCY-Acid Diges & $\mu \mathrm{g} / \mathrm{mL}$ & 100 & $<5.00 \mathrm{k}=03$ & $<0.500$ & nia & nia & $n / a$ & n/a & 0.5 \\
\hline SO21000917 & $\mathrm{B}$ & Bismuth -KCP-Acid Digest/Liq & $\mu \mathrm{g} / \mathrm{mL}$ & 98.4: & $<0.100$ & $<10.0$ & $n / a$ & $n / 4$ & $n / 2$ & $n / 4$ & 10 \\
\hline S02T000917 & B & Calcium -KCP-Acid Digest-Liq & $\mu \mathrm{g} / \mathrm{mL}$ & 99.4 & $<0.100$ & $<10.0$ & $n / a$ & nia & $n / a$ & $n / 2$ & 10 \\
\hline 502T000917 & $\mathrm{B}$ & Cadmium-[CP-Acid Digsst-Liq & $\mu \mathrm{g} / \mathrm{m} \mathrm{L}$ & 97.1 & $<5.000-03$ & $<0.500$ & $\mathrm{n} / \mathrm{a}$ & $n / a$ & $\mathrm{n} / \mathrm{a}$ & $n / \mathrm{a}$ & 0.5 \\
\hline 5021000917 & B & Cerium-ICP-Avid Diget-Liq & $\mu \mathrm{\mu} / \mathrm{mL}$ & $n / a$ & $<0.100$ & $<10.0$ & $n / a$ & $n / a$ & nia & $n / \mathbf{a}$ & 10 \\
\hline
\end{tabular}


RPP 12077 Rev, 0

\begin{tabular}{|c|c|c|c|c|c|c|c|c|c|c|c|c|c|c|c|c|c|c|}
\hline \begin{tabular}{l|l} 
& \\
$\vdots$ \\
$\mathbf{y}$
\end{tabular} & $\pi=$ & & 9 & & 8 & 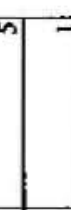 & 9 & & 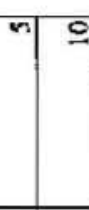 & 9 & $\pi$ & 可 & & 0 & & & 9 & -9 \\
\hline 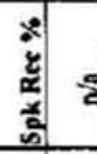 & aี & हี & ㅁำ & คี & $\bar{E}=5$ & $\tilde{5}$ & ㄹำ & 券 & 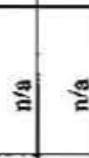 & हี & ตี & हี & 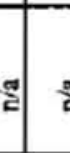 & है & 를 & & हี & $=5$ \\
\hline$=$ & 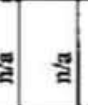 & & & 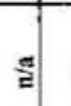 & & & & & & & है & & & & & 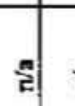 & दี & 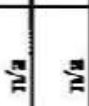 \\
\hline
\end{tabular}

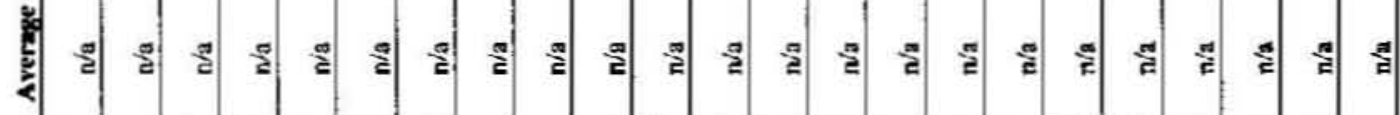

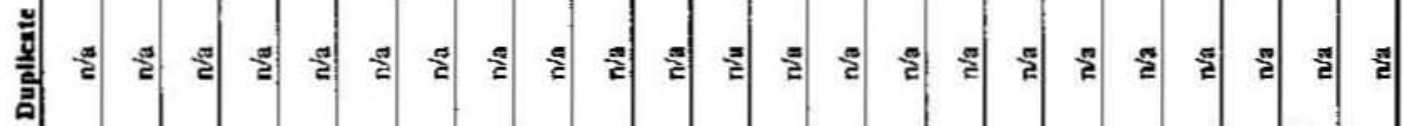

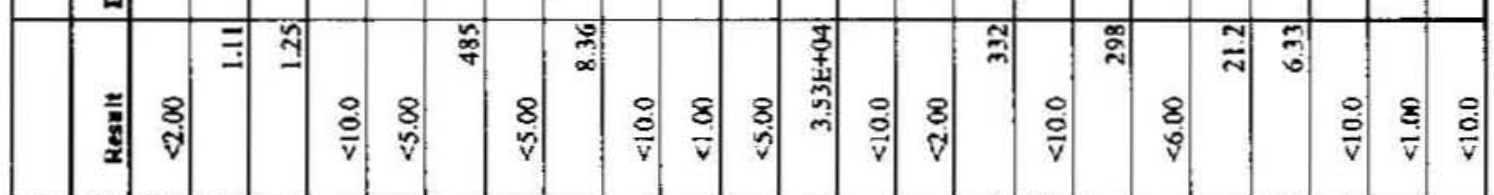

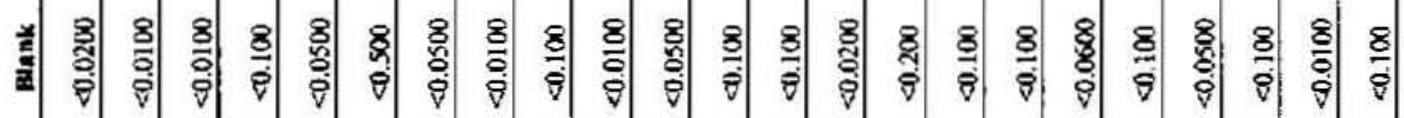

|

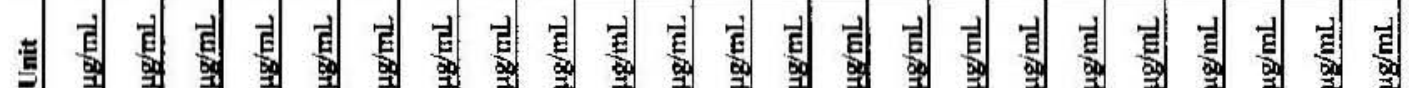

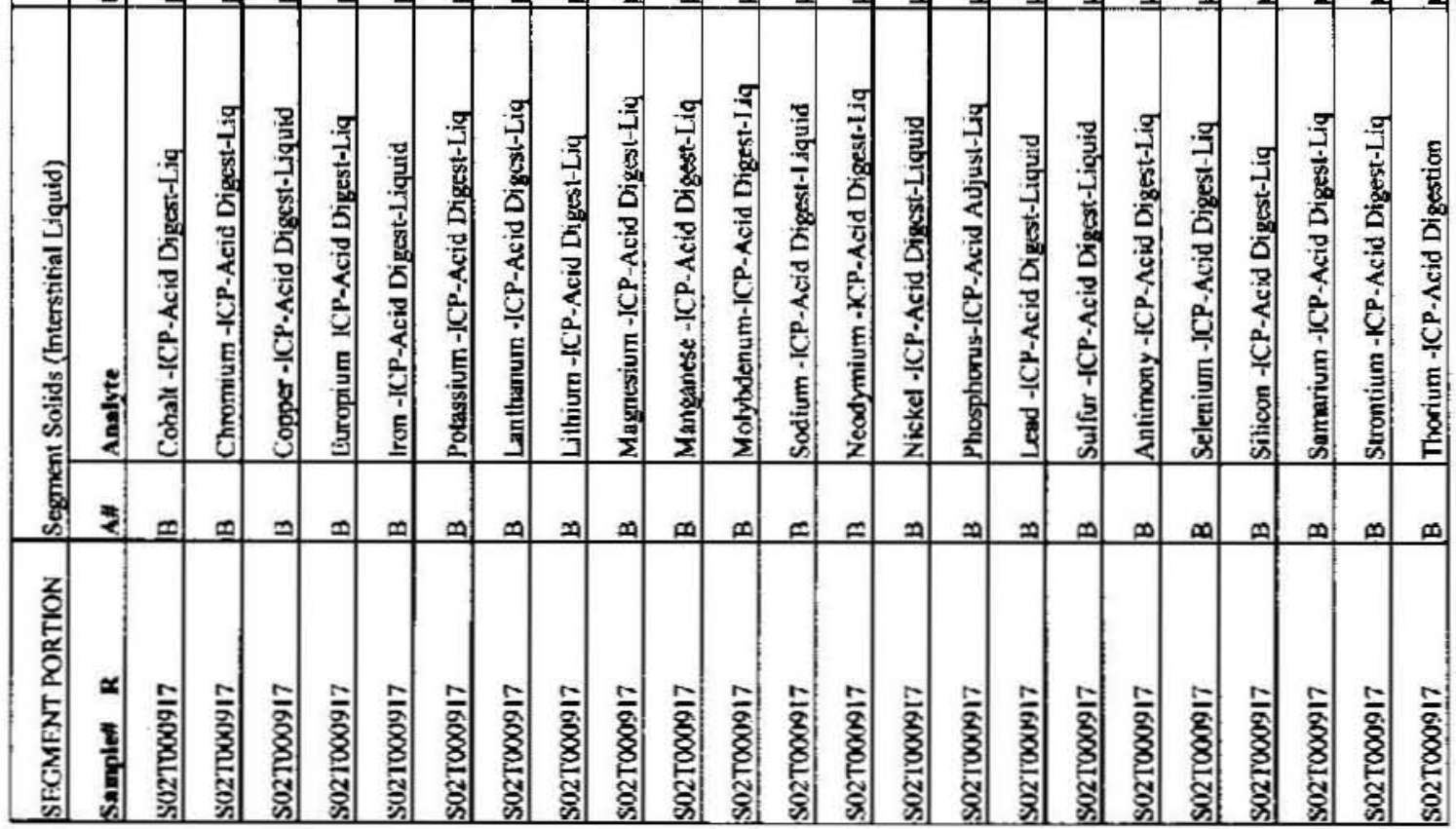




\begin{tabular}{|c|c|c|c|c|c|c|c|c|c|c|c|}
\hline SEGMENT PORTION & $\operatorname{seg} n$ & nt Solids (Interstitial Liquid) & & & & & & & & & \\
\hline Samplet R & A\# & Analyte & Linit & Stundard $\%$ & Blank & Result & Dupllcate & Avernge & RPD \% & Spk Rex \% & Det LImit \\
\hline SO2T000917 & B & Titanium-ICP-Acid Digest-Liq & $\mu \mathrm{g} / \mathrm{mL}$ & 96.9 & $\infty 0.0100$ & $\langle 1 .(X)$ & $n / a$ & $\mathrm{n} / \mathbf{a}$ & $n / 2$ & $n / a$ & 1 \\
\hline SO2T0000917 & B & Thallium-ICP-Acid Digest-Liq & $\mu \mathrm{g} / \mathrm{mL}$ & $n / a$ & $<0.200$ & 20.0 & $n / a$ & $n / 2$ & $n / 2$ & $n / 3$ & 20 \\
\hline SO2T000917 & B & Uranium -ICP-Acid Digest-I iq & $\mu \mathrm{g} / \mathrm{mL}$ & $n / \mathrm{a}$ & $<0.250$ & $1.59 \mathrm{E}+03$ & $n / 3$ & $n / a$ & $\mathbf{n} / \mathbf{a}$ & $n / a$ & 25 \\
\hline 5027000917 & B & Vanadium-ICP-Acid Digest-Liq & $\mu \mathrm{g} / \mathrm{mI}$. & 100 & $\$ 0.0500$ & $<5.00$ & n/a & $n / a$ & $n / a$ & n/a & $\underline{s}$ \\
\hline 5027000917 & B & Ytrrium - - CP- $-\Lambda$ cid Digestion & $\mu \mathrm{g} / \mathrm{mL}$ & $n / a$ & $<0.0100$ & $<1.00$ & $n / \mathrm{u}$ & noa & $n / a$ & nia & 1 \\
\hline $\mathrm{S} 02 \mathrm{~T} 000917$ & B & 7inc -ICP-Acid Digest-Liquid & $\mu \mathrm{g} / \mathrm{mL}$ & 95.4 & $<0.0100$ & $<1.00$ & $n / a$ & $n / a$ & $n / a$ & $n / \mathbf{a}$ & 1 \\
\hline SO2T000917 & B & Zirconium -ICP-Acid Digest-Liq & $\mu \mathrm{g} / \mathrm{mL}$ & 92.6 & $<0.0100$ & $<1.00$ & n/a & $n / a$ & $n / a$ & $n / \mathbf{a}$ & 1 \\
\hline SEGMENT PORTION & Segn & nt Solias (Settled Solids) & & & & & & & & & \\
\hline Sample\# A & A\# & Anabyte & Unit & Standard \% & Btank & Result & Duplicate & Average & RPD \% & Spk Rec \% & Det Limit \\
\hline SO2T000905 & & Builk Density of Sarmple & $\mathrm{g} / \mathrm{mL}$ & n'a & nia & 1.37 & $n / a$ & n/a & $n / a$ & $n / a$ & 0.5 \\
\hline SO2T000905 & & Yolume $\%$ Centrifuged Solids & $\%$ & n'a & $n / \mathbf{a}$ & 60 & $n / a$ & $\pi / a$ & na & $\mathrm{n} / \mathrm{a}$ & $n / a$ \\
\hline
\end{tabular}

Note: $\quad \mathbf{n} / \mathbf{a}=$ not applicable

ICP = inductively coupled plasma

$\mathrm{TGA}=$ thermogravimetric analysis

TIC $=$ total inorganic carbon

$\mathrm{TOC}=$ total organic carbon 
RPP 12077 Rev. 0

\section{REFERENCES}

Baker, H. L., 2002, "Tank 241-AY-102 Core Samples Analytical Results for the Final Report," (letter FH-0202868 Rev. 0 to G. A. Stanton, CHG, June 25), Fluor Hanford, Richland, Washington. 
RPP 12077 Rev. 0 
RPP 12077 Rev. 0

Table D-1. Supernatant Simulant Formulation and Makeup

\begin{tabular}{|l|l|r|c|}
\hline \multicolumn{1}{|c|}{ Analyte } & \multicolumn{1}{|c|}{ Simulant } & grams/L & $\begin{array}{c}\text { Order of } \\
\text { Addition }\end{array}$ \\
\hline $\mathrm{OH}$ & $\mathrm{NaOH}$ & 2.277 & 2 \\
\hline $\mathrm{TOC}$ & $\mathrm{Na}_{4} \mathrm{EDTA}$ & 6.442 & 3 \\
\hline $\mathrm{TIC}$ & $\mathrm{Na}_{2} \mathrm{CO}_{3}$ & 97.745 & 11 \\
\hline $\mathrm{F}$ & $\mathrm{NaF}$ & 0.174 & 4 \\
\hline $\mathrm{Cl}$ & $\mathrm{NaCl}$ & 0.254 & 5 \\
\hline $\mathrm{NO}_{2}$ & $\mathrm{NaNO}_{2}$ & 11.184 & 6 \\
\hline $\mathrm{SO}_{4}$ & $\mathrm{Na}_{2} \mathrm{SO}_{4}$ & 3.285 & 7 \\
\hline $\mathrm{NO}_{3}$ & $\mathrm{NaNO}_{3}$ & 0.469 & 8 \\
\hline $\mathrm{PO}_{4}$ & $\mathrm{Na}_{3} \mathrm{PO}_{4}{ }^{*} 12 \mathrm{H}_{2} \mathrm{O}$ & 14.209 & 9 \\
\hline $\mathrm{Al}$ & $\mathrm{NaAlO}_{2}$ & 2.731 & 1 \\
\hline $\mathrm{K}$ & $\mathrm{KHCO}_{3}$ & 1.351 & 10 \\
\hline
\end{tabular}

Prepare the supernatant simulant in the following manner:

1. One liter of reagent grade water in a $1500-\mathrm{mL}$ or $2000-\mathrm{mL}$ beaker.

2. Place on a hot plate stirrer with a Teflon coated magnet.

3. Heat to $80^{\circ} \mathrm{C}$.

4. Add the $\mathrm{NaAlO}_{2}$ slowly.

5. After the $\mathrm{NaAlO}_{2}$ dissolves, SLOWLY and CAREFULLY add the $\mathrm{NaOH}$.

6. After dissolution, slowly add the $\mathrm{Na}_{4}$ EDTA.

7. Turn off the heat and allow the solution to start to cool.

8. Reagents (in the order of addition column) numbered 4 through 10 may be added in any order.

9. When the solution is $\sim 30^{\circ} \mathrm{C}$, then add the $\mathrm{Na}_{2} \mathrm{CO}_{3}$ followed by $\mathrm{KHCO}_{3}$.

10. Set aside and allow to cool to room temperature.

11. Store in a rubber stoppered bottle. 
RPP 12077 Rev. 0

Table D-2. Sludge Simulant Formulation and Makeup

\begin{tabular}{|l|l|c|}
\hline \multicolumn{1}{|c|}{ Analyte } & \multicolumn{1}{|c|}{$\begin{array}{c}\text { Simulant } \\
\text { (Reagent) }\end{array}$} & grams/L \\
\hline $\mathrm{TOC}$ & $\mathrm{Na}_{4} \mathrm{EDTA}$ & 130.843 \\
\hline $\mathrm{TIC}$ & $\mathrm{Na}_{2} \mathrm{CO}_{3}$ & 161.633 \\
\hline $\mathrm{Al}$ & $\mathrm{NaAlO}_{2}{ }^{*} 2 \mathrm{H}_{2} \mathrm{O}$ & 272.459 \\
\hline $\mathrm{Ca}$ & $\mathrm{Ca}\left(\mathrm{NO}_{3}\right) 2 * 4 \mathrm{H}_{2} \mathrm{O}$ & 22.155 \\
\hline $\mathrm{Fe}$ & $\mathrm{FeSO}_{4} * 7 \mathrm{H}_{2} \mathrm{O}$ & 442.906 \\
\hline $\mathrm{Mn}$ & $\mathrm{KMnO}_{4}$ & 51.874 \\
\hline $\mathrm{Na}$ & $\mathrm{NaOH}$ & 116.158 \\
\hline $\mathrm{PO}_{4}$ & $\mathrm{Na}_{3} \mathrm{PO}_{4}{ }^{*} 12 \mathrm{H}_{2} \mathrm{O}$ & 13.542 \\
\hline $\mathrm{F}$ & $\mathrm{NaF}$ & 0.151 \\
\hline $\mathrm{Cl}$ & $\mathrm{NaCl}$ & 0.200 \\
\hline $\mathrm{NO}_{2}$ & $\mathrm{NaNO}_{2}$ & 6.270 \\
\hline $\mathrm{SO}_{4}$ & $\mathrm{FeSO}_{4} * 7 \mathrm{H}_{2} \mathrm{O}$ & $\mathrm{FeSO}_{4} * 7 \mathrm{H}_{2} \mathrm{O}$ above \\
\hline
\end{tabular}

Prepare the sludge simulant in the following manner:

1. Three Hundred $\mathrm{mL}$ of reagent grade water in a $1500-\mathrm{mL}$ or $2000-\mathrm{mL}$ beaker.

2. Place on a hot plate stirrer with a Teflon coated magnet.

3. Heat to $80^{\circ} \mathrm{C}$.

4. The order of addition for the sludge is not critical.

5. Make sure that as reagents are added as much dissolution as possible is achieved before the addition of the next reagent..

6. Turn off the heat and allow the solution to start to cool to room temperature.

7. Store in a rubber stoppered bottle. 
RPP 12077 Rev. 0

\section{APPENDIX E}

\section{ELECTROCHEMICAL SCANS SEGMENT 13R1}


RPP 12077 Rev. 0

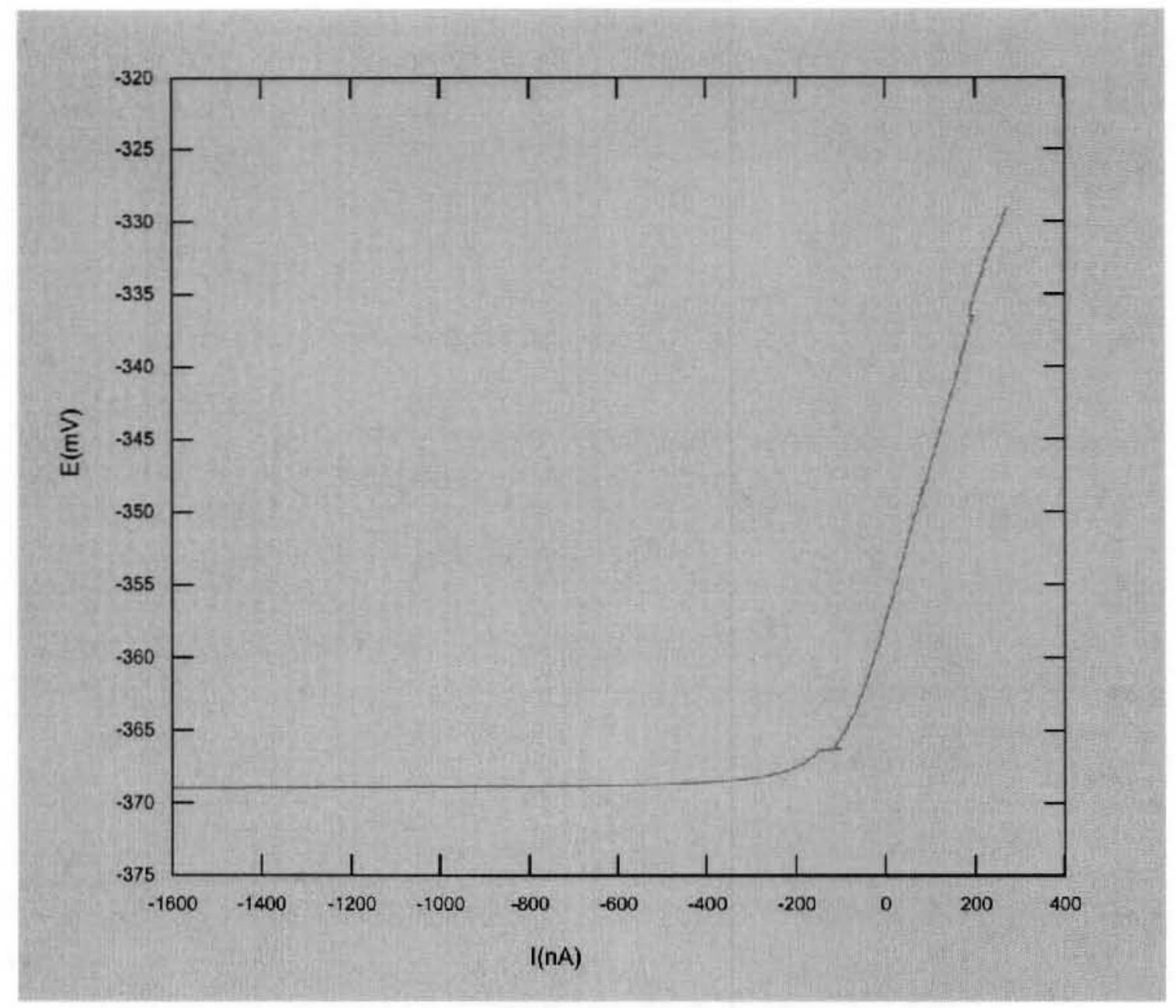

Figure E-1. Segment 13R1 Linear Polarization Plot for A515 Grade 60 Coupon (twelve hour $\mathrm{E}_{\mathrm{CORR}}$ scanned at $0.166 \mathrm{mV} / \mathrm{sec}, \pm 0.02 \mathrm{mV}$ versus open circuit, $24^{\circ} \mathrm{C}$ ) 
RPP 12077 Rev. 0

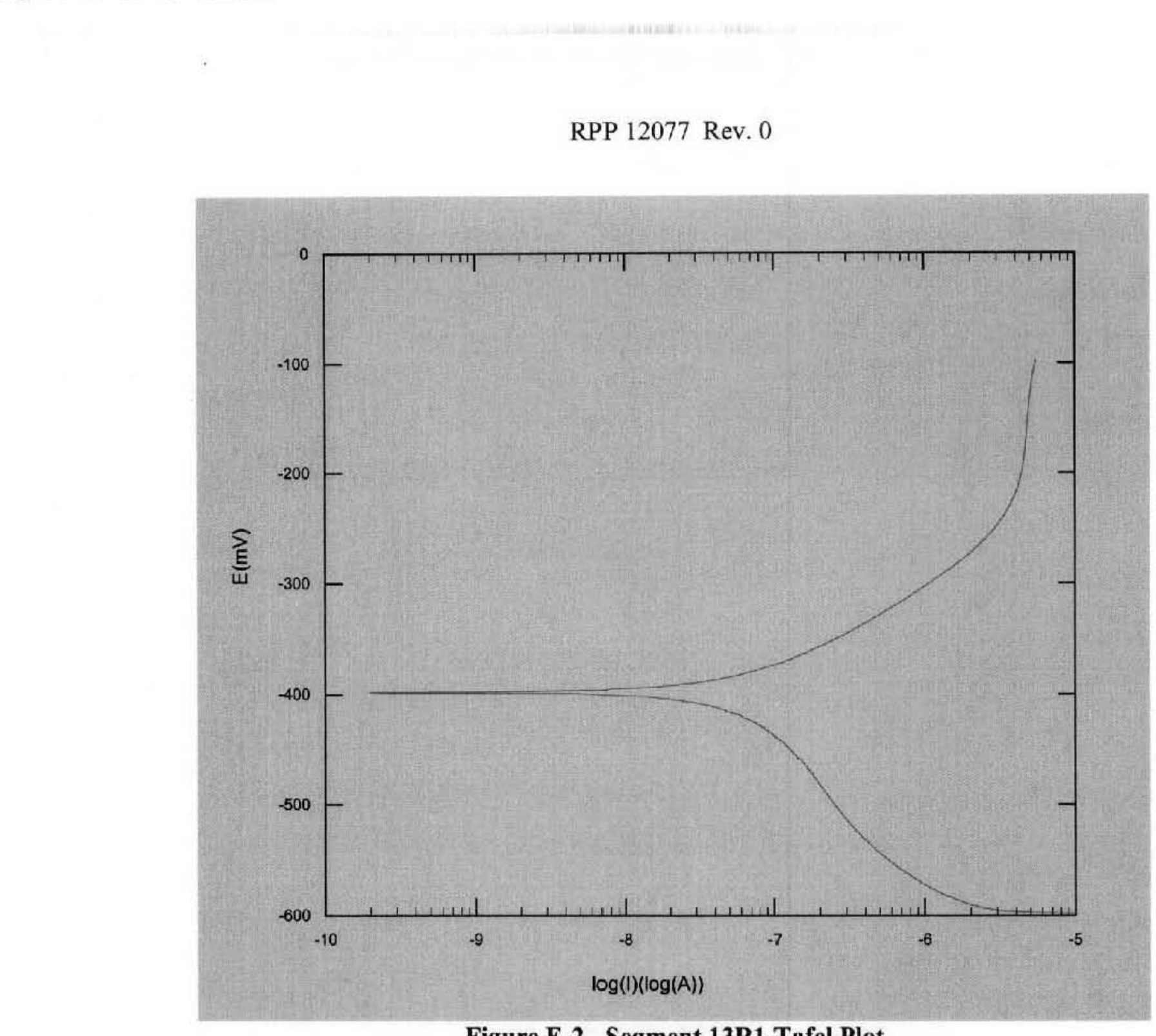

Figure E-2. Segment 13R1 Tafel Plot

Scanned after the linear polarization presented in Figure E-1. The A515 Grade 60 coupon was scanned at a rate of $0.166 \mathrm{mV} / \mathrm{sec}, \pm 0.250 \mathrm{~V}$ versus open circuit, $24^{\circ} \mathrm{C}$. scanned at a rate of $0.166 \mathrm{mV} / \mathrm{sec}, \pm 0.250 \mathrm{~V}$ versus open circuit, $24^{\circ} \mathrm{C}$.

(1)


RPP 12077 Rev. 0

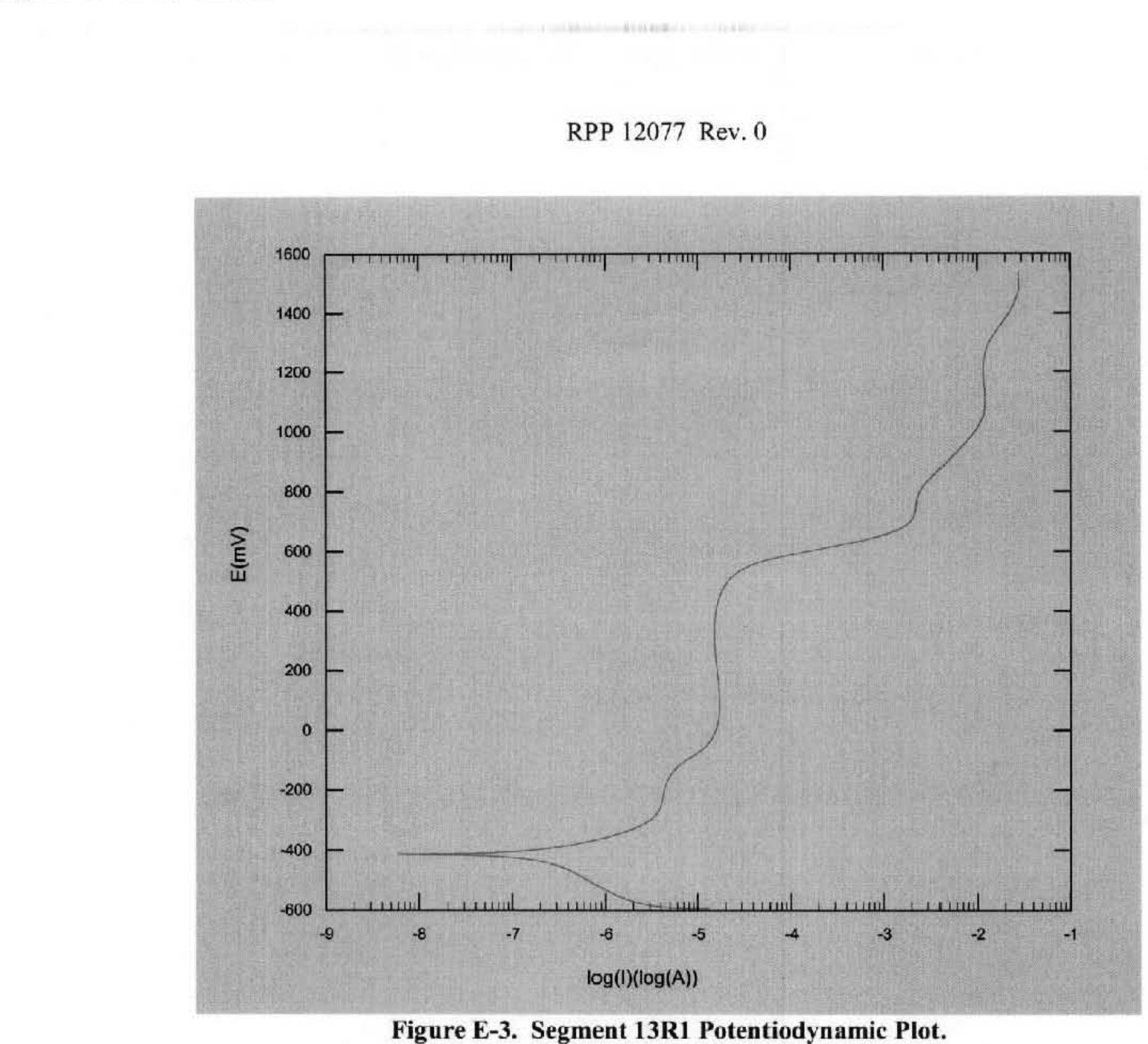

Figure E-3. Segment 13R1 Potentiodynamic Plot.

Scanned after the Tafel Plot presented in Figure E-2. The A515 Grade 60 coupon was scanned at a rate of $0.166 \mathrm{~V} / \mathrm{sec}$, from $-0.300 \mathrm{mV}$ versus open circuit to $1.6 \mathrm{~V}, 24^{\circ} \mathrm{C}$. a rate of $0.166 \mathrm{~V} / \mathrm{sec}$, from $-0.300 \mathrm{mV}$ versus open circuit to $1.6 \mathrm{~V}, 24 \mathrm{C}$.

\title{
at
}

.

$\sqrt{3}$ 
RPP 12077 Rev. 0

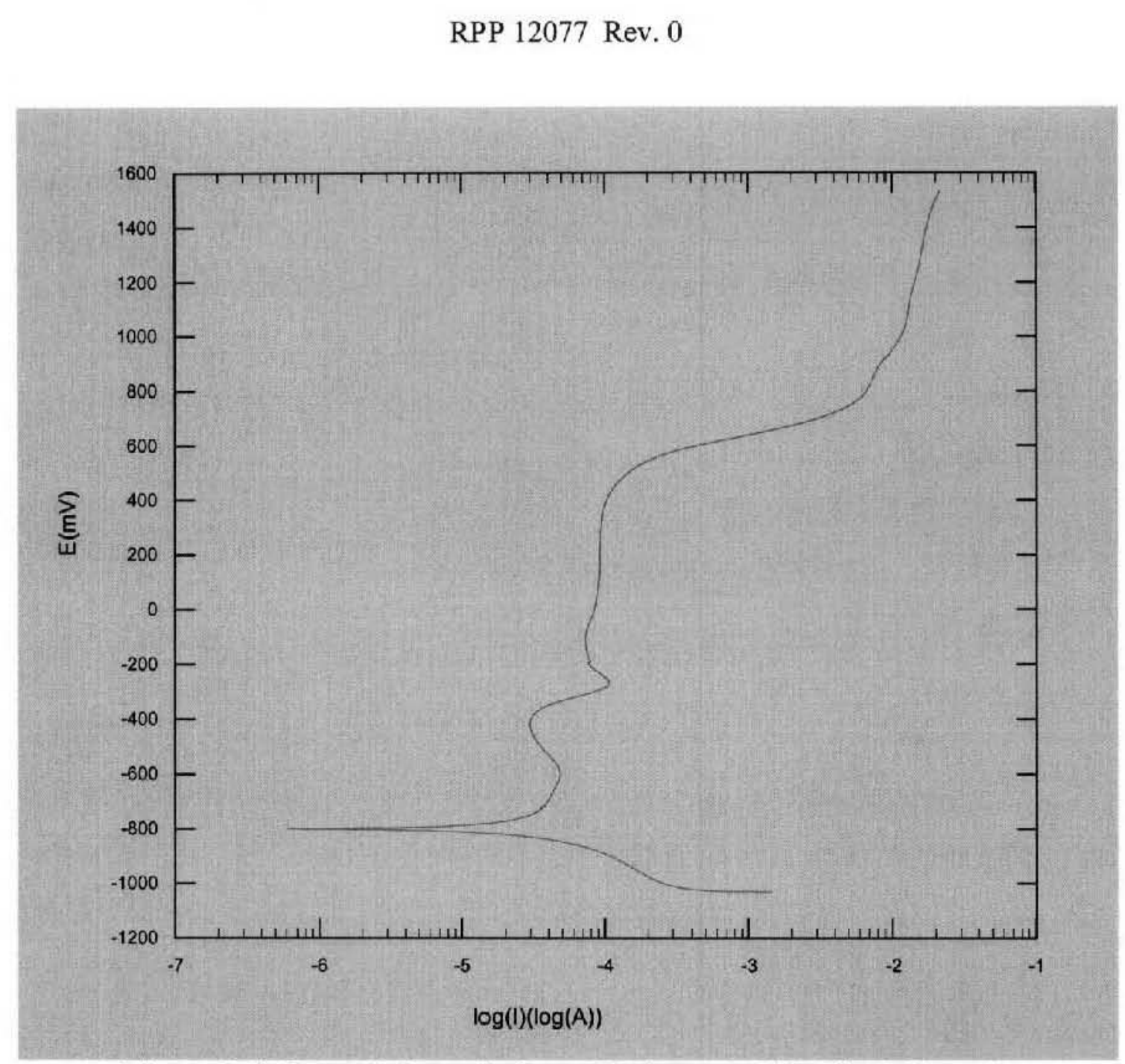

Figure E-4. Potentiodynamic Scan, Platinum As Working Electrode

\section{(n)}
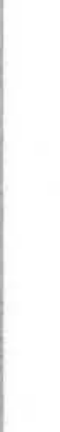

ev. 0
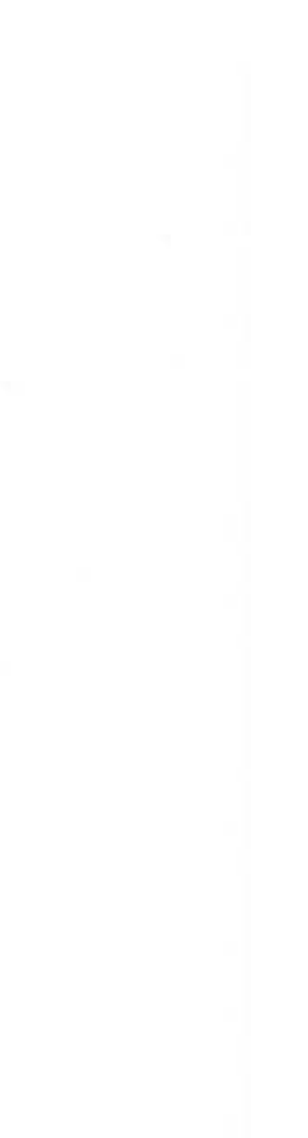

\footnotetext{
$\sqrt{2}$
}

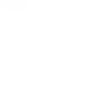


RPP 12077 Rev. 0

\begin{abstract}
APPENDIX F CIECTROCHEMICAL SCANS OE SEGMENTS $13 \mathrm{R}$ AND 13 BR

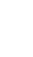

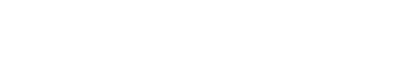

\section{ELECTROCHEMICAL SCANS OF SEGMENTS 13R1 AND 13BR}

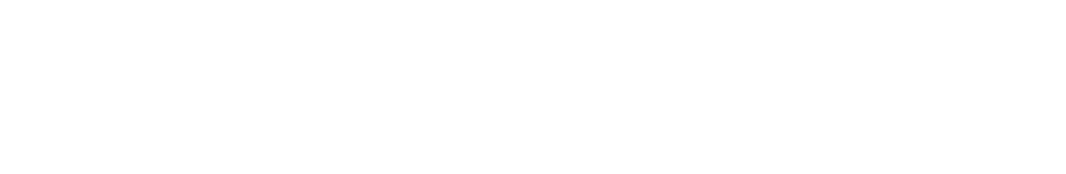




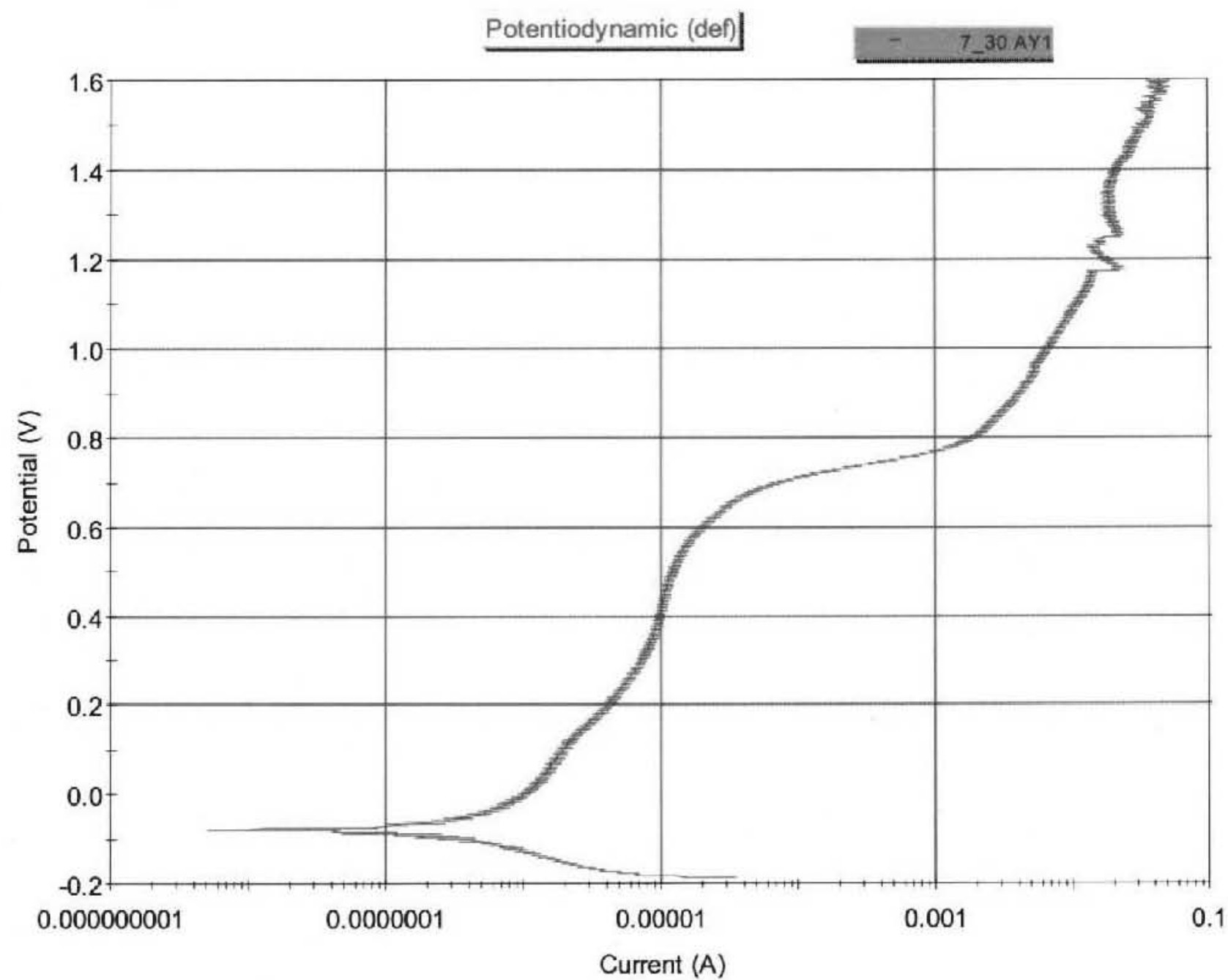

Figure F-1. Potentiodynamic scan of A515 60 coupon at $24^{\circ} \mathrm{C}$ 


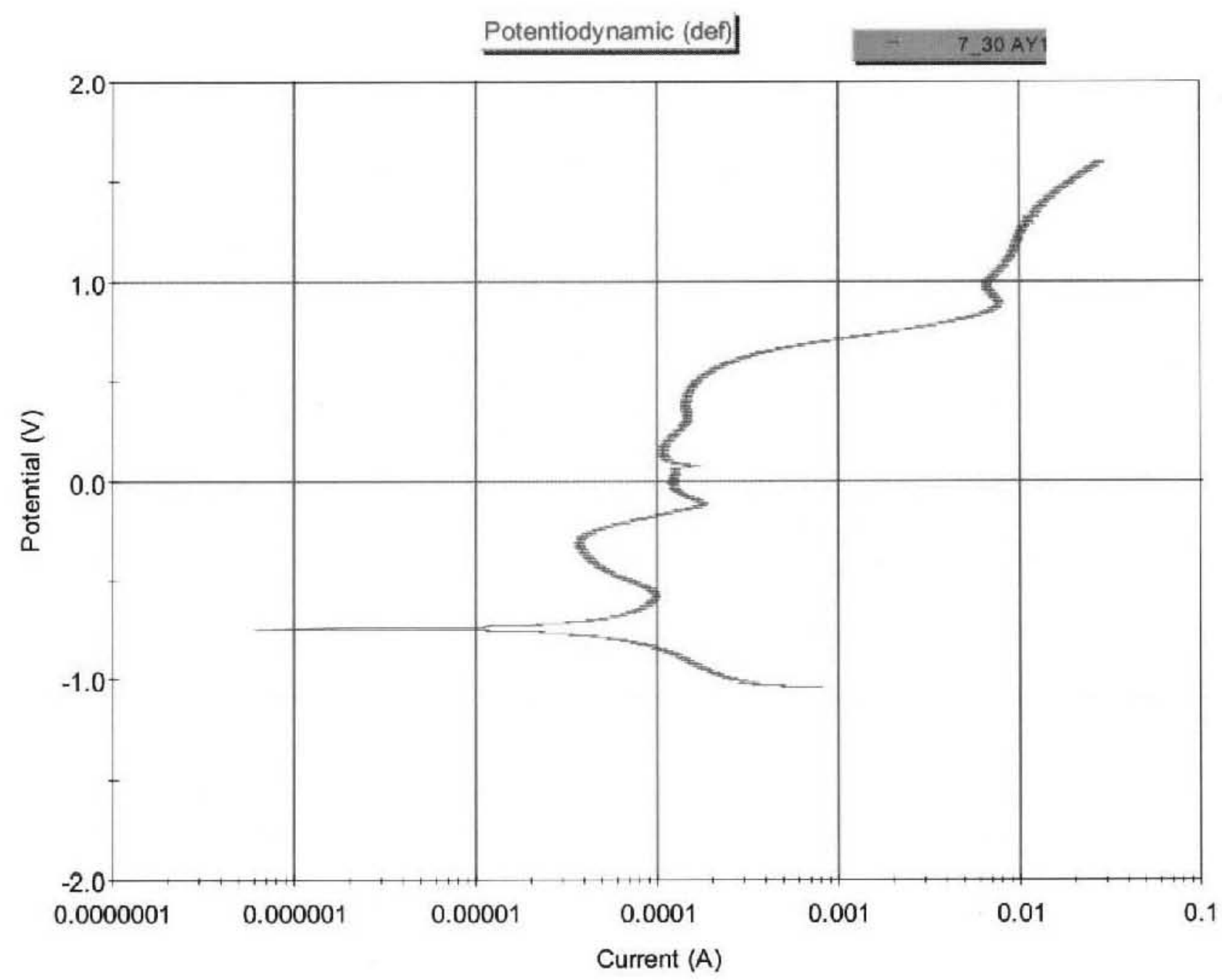

Figure F-2. Potentiodynamic Scan of Platinum Electrode, $24^{\circ} \mathrm{C}$ 


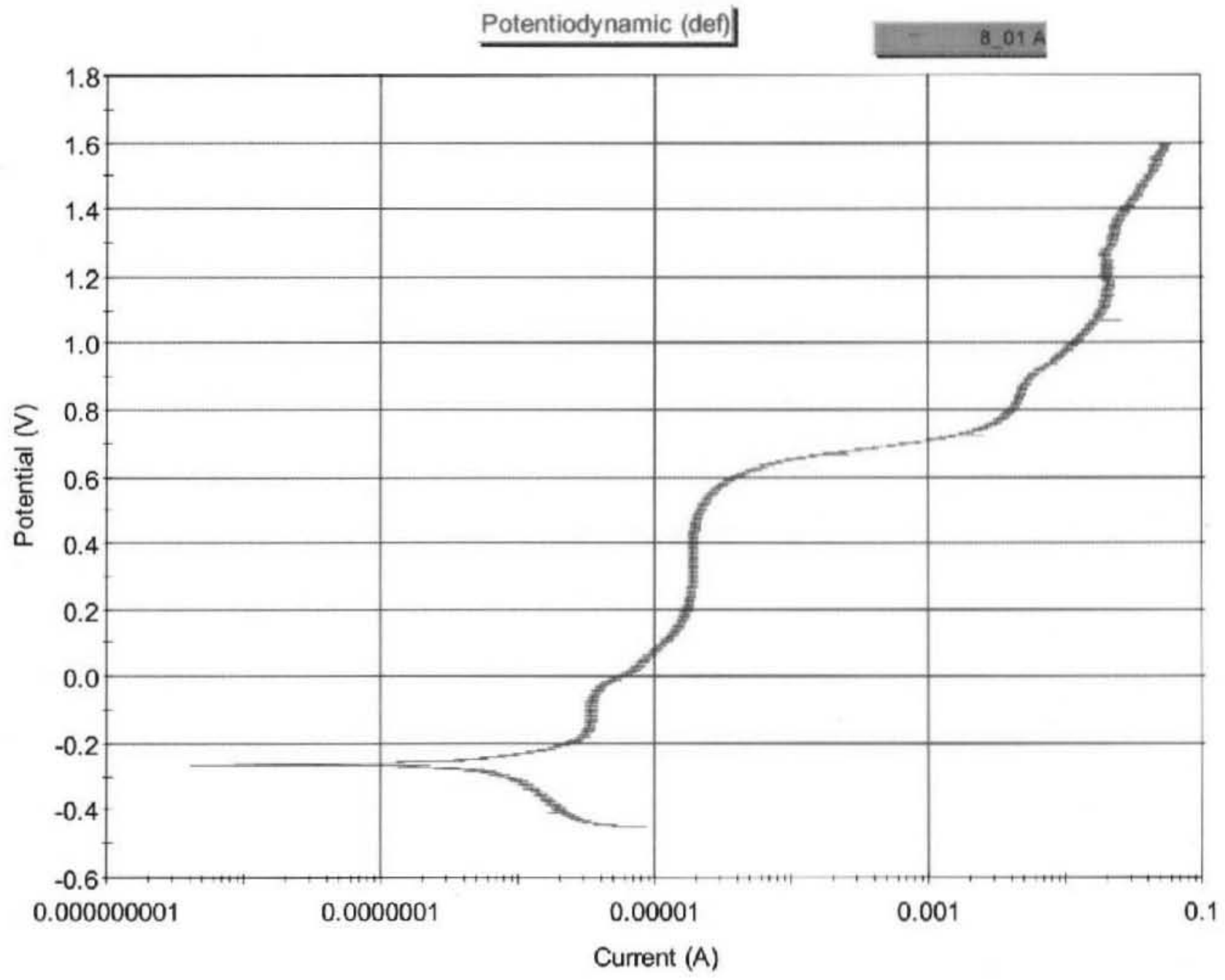

Figure F-3. Potentiodynamic Scan of A515 60 Coupon at $40^{\circ} \mathrm{C}$ 


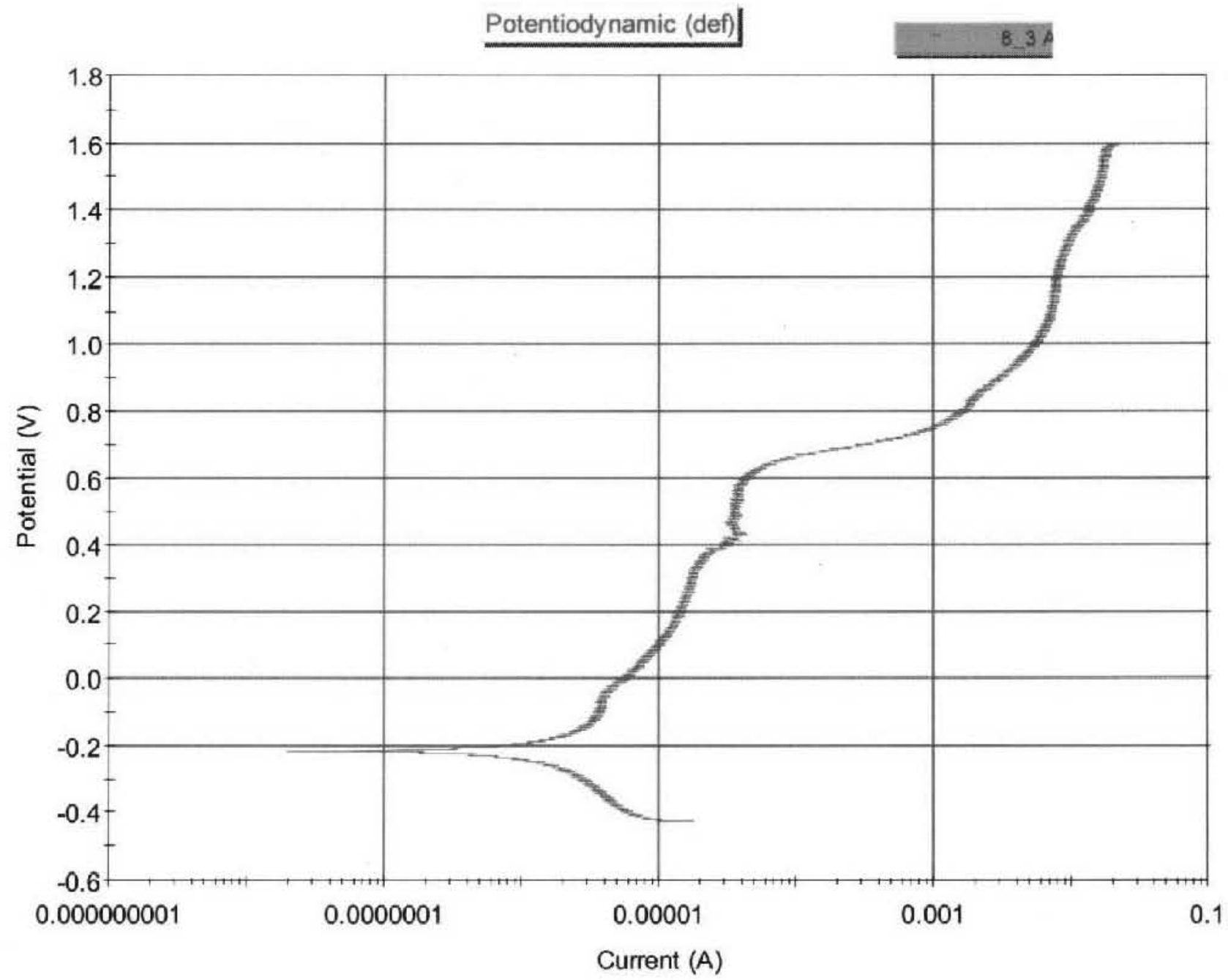

Figure F-4. Potentiodynamic Scan of A515 60 Coupon at $60^{\circ} \mathrm{C}$ 


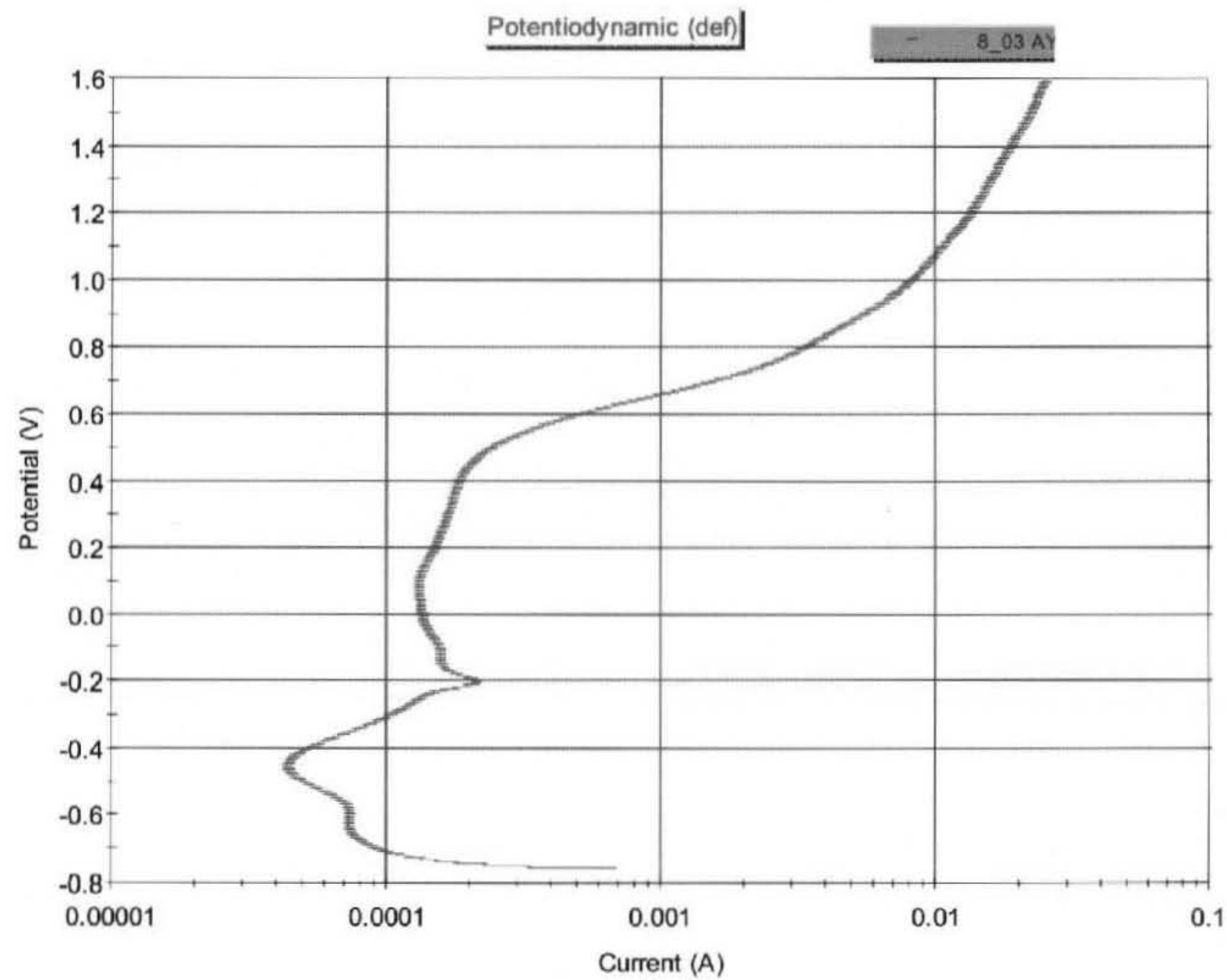

Figure F-5. Potentiodynamic Scan of Platinum Electrode, $60^{\circ} \mathrm{C}$. 


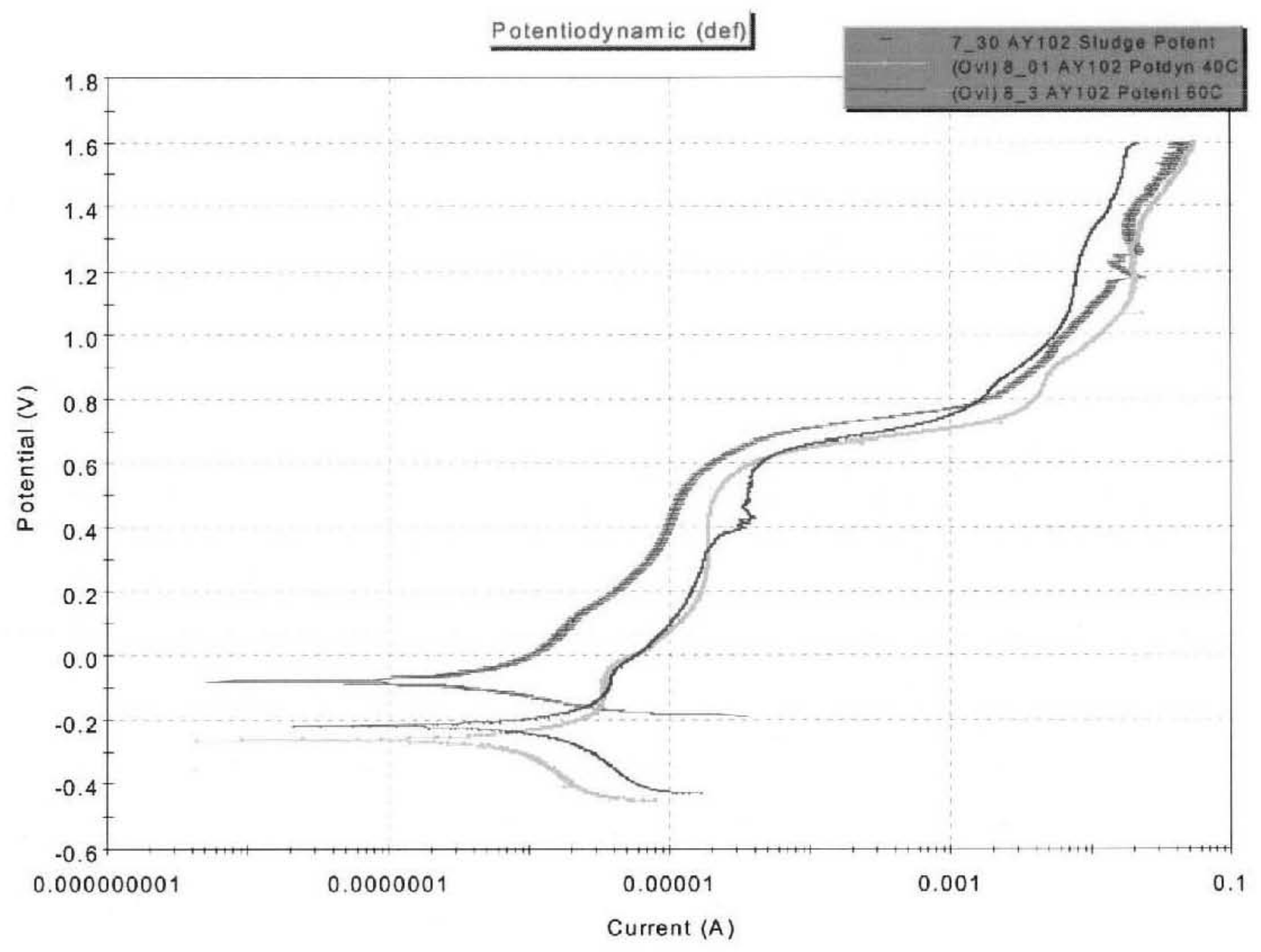

Figure F-6. Potentiodynamic Scans of A5125 60 in 13R1 and 13BR Sludge, at $24^{\circ} \mathrm{C}, 40^{\circ} \mathrm{C}$, and $60^{\circ} \mathrm{C}$ 